\title{
sobider
}

Sosyal Bilimler Dergisi / The Journal of Social Sciences

Akademik Sosyal Araştırmalar Dergisi, Yıl: 8, Sayı: 52, Haziran 2021, s. 20-38

ISSN: 2149-0821 Doi Number:http://dx.doi.org/10.29228/SOBIDER.50971

\section{Hosein NAJAFI}

Atatürk Üniversitesi Sosyal Bilimler Enstitüsü Fars Dili ve Edebiyatı ABD. Doktora Öğrencisi najafihossein396@gmail.com

\section{Prof. Dr. Veyis DEĞİRMENÇAY}

Atatürk Üniversitesi Edebiyat Fakültesi Fars Dili ve Edebiyatı Bölümü, drveyis@atauni.edu.tr

\section{THE REFLECTION OF MYTH IN THE WORKS OF ZOYA PIRZAD}

\begin{abstract}
The relationship between myth and language and literature, especially fiction, has long been created in human history and has linked the fate of these two.

The works of Zoya Pirzad, one of the famous female story writers, are noteworthy for her broad awareness of myth and its bold presence in her stories.

The myth is reflected in the works of this author in various forms. Mythological characterization, mythological names, mythological themes and ideas are among them.

Her main concem in using myth is the expression of important issues of women in the male / dominated society and the efforts to promote women's status and women's identity.

The present research deals with various forms of reflection of myth in the writings of this outhor.
\end{abstract}

Keywords: Myth, archetype, Zoya Pirzad

$$
\text { بـازتـاب اسطوره در آثـار زويـا پـيـرزاد }
$$

حسين نـجفى 


\section{״ـروفسور دكتـر ويـس دخـرمـانــــاى}

\section{جـكـــ 0}

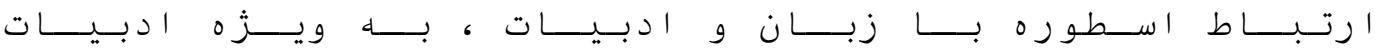

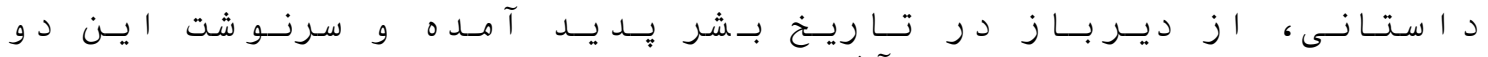

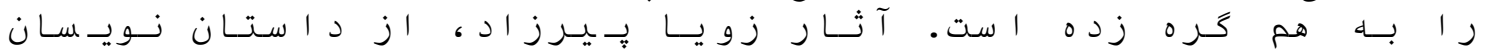

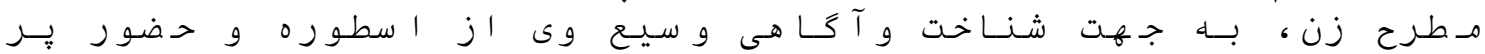

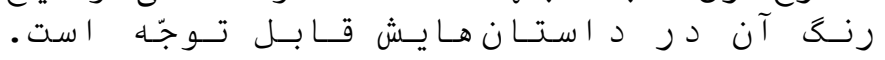

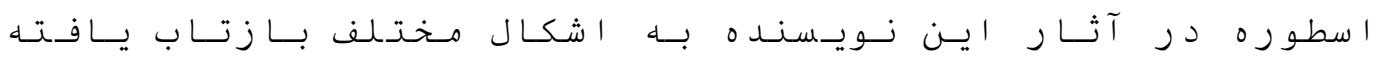

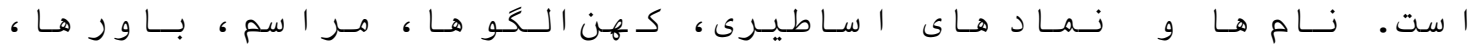

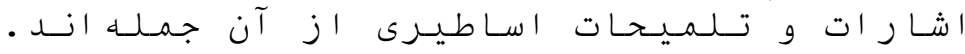

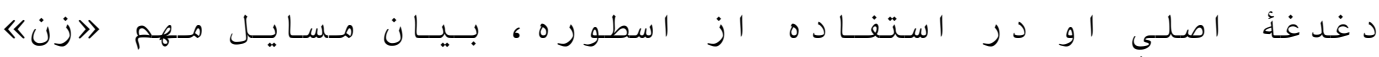

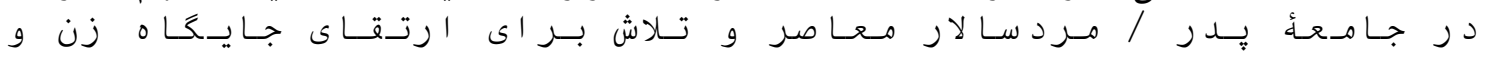

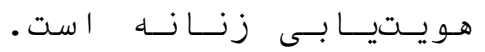

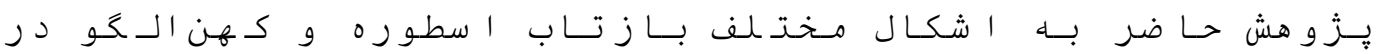

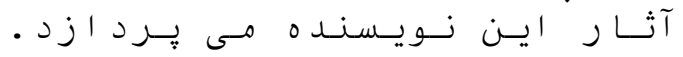

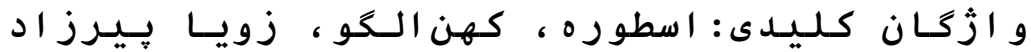

\section{مـقــدّ مــه}

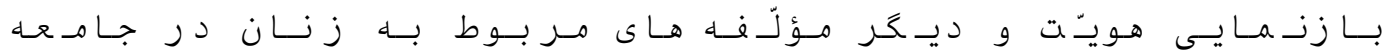

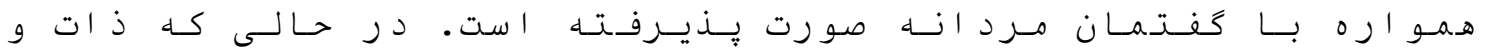

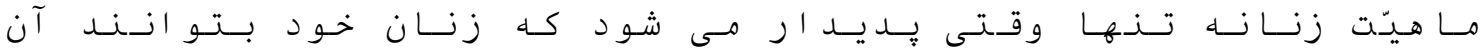

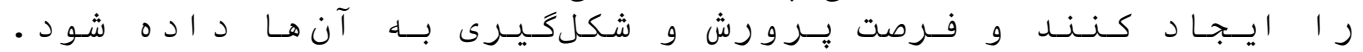

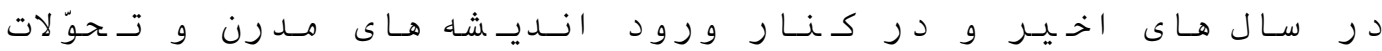

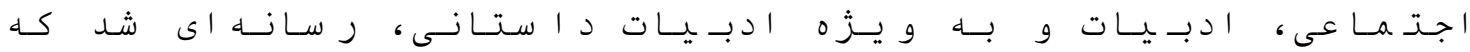

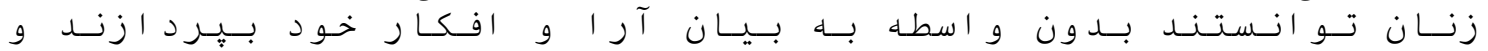

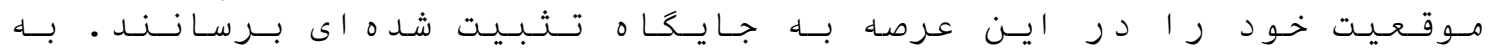

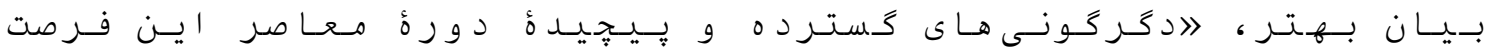

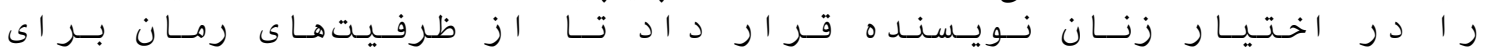

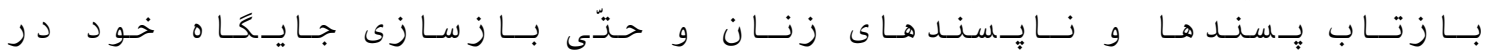

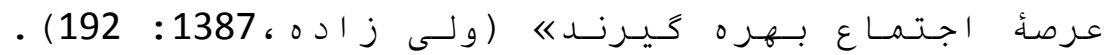

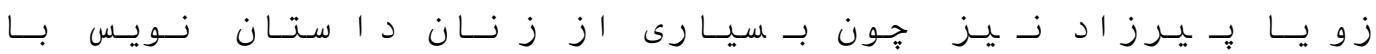

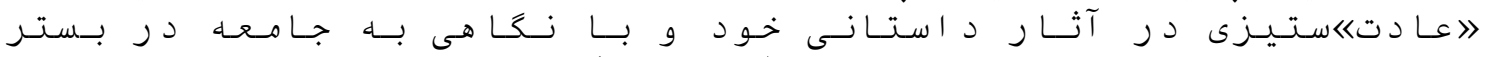

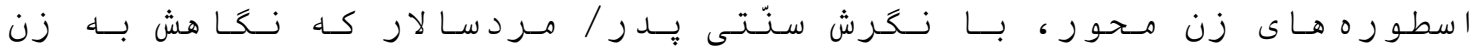

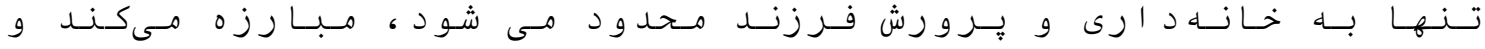

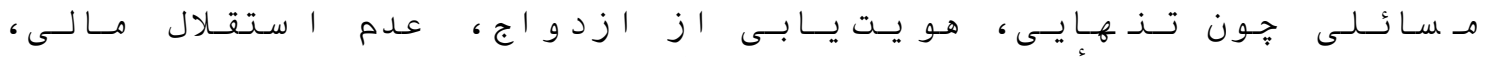

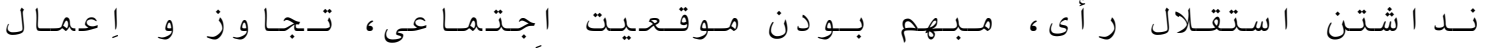

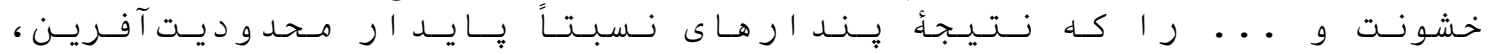

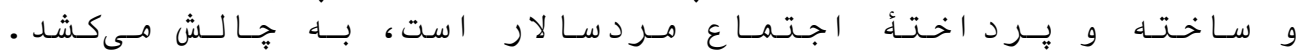

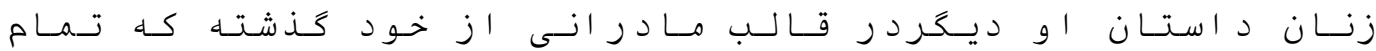

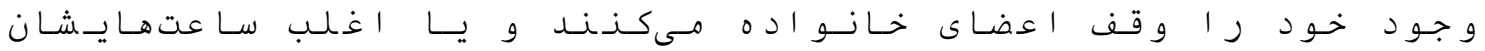

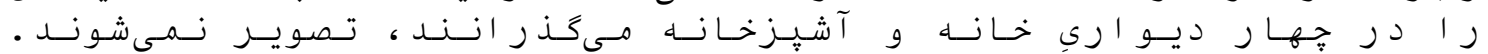

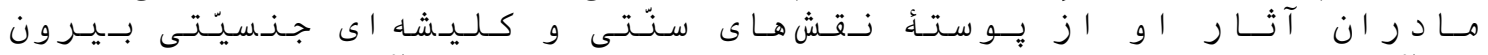

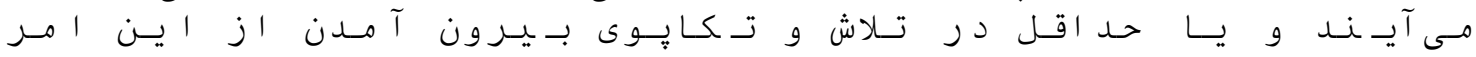




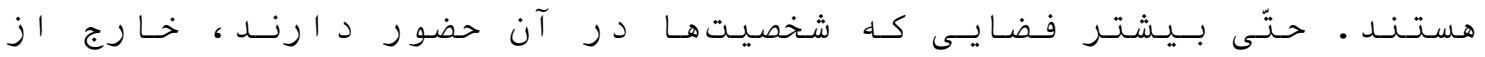

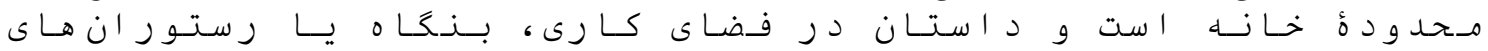

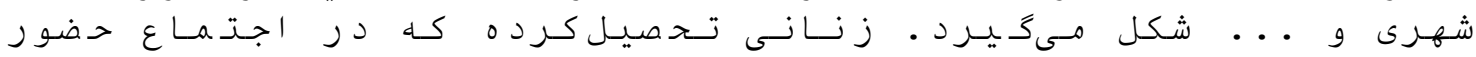

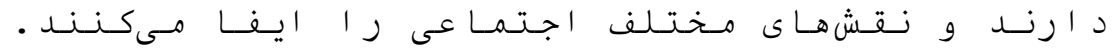

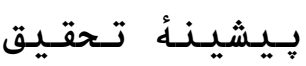

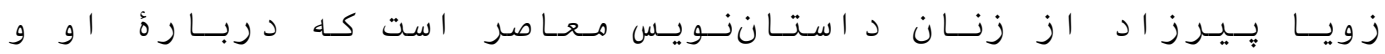

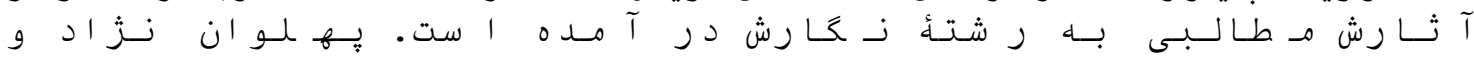

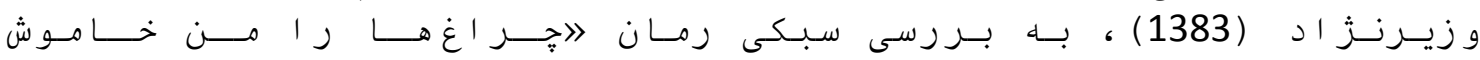

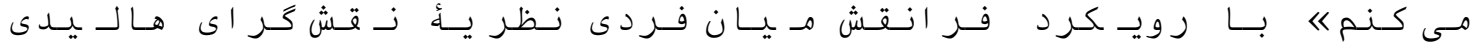

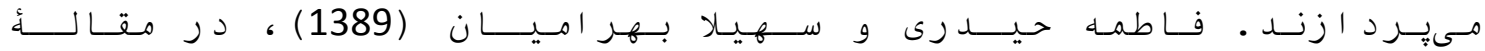

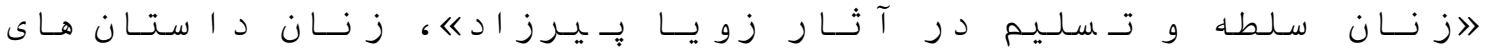

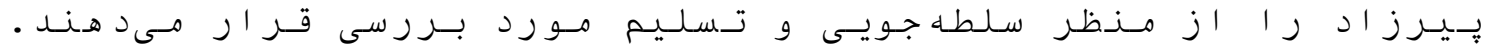

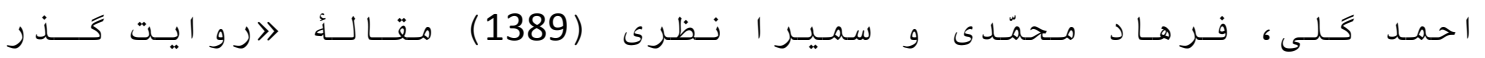

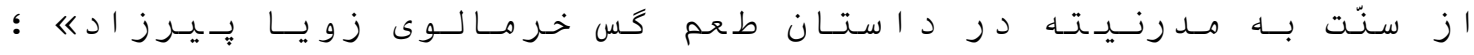

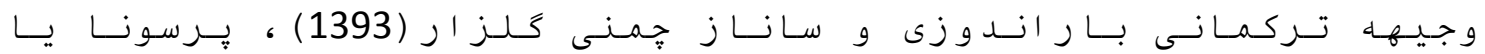

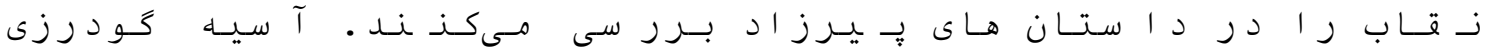

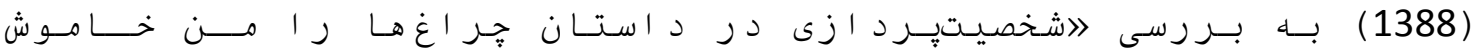

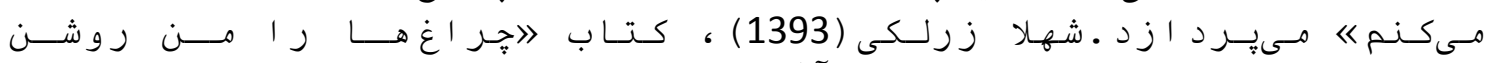

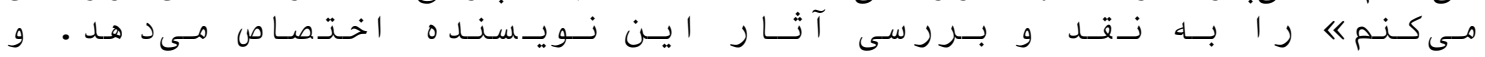

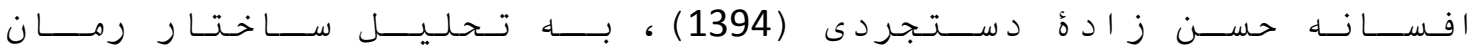

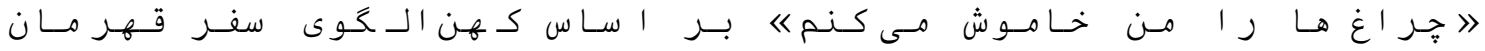

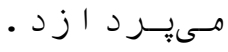

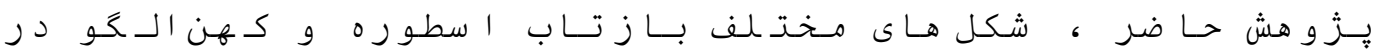

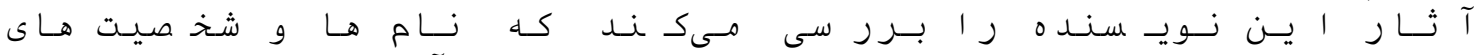

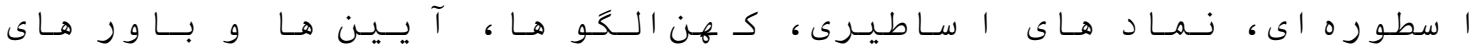

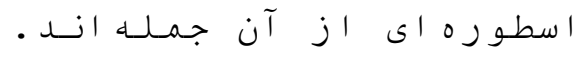

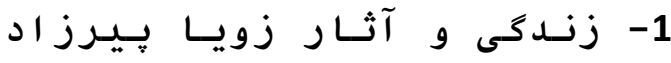

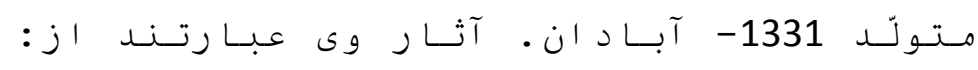

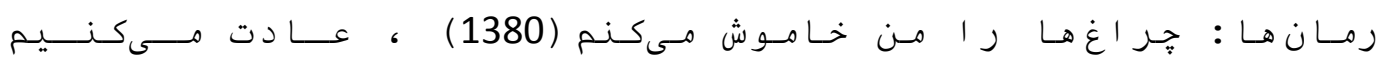

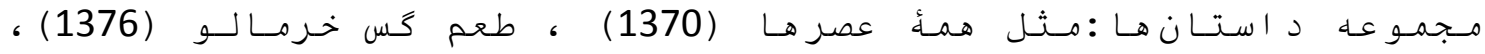

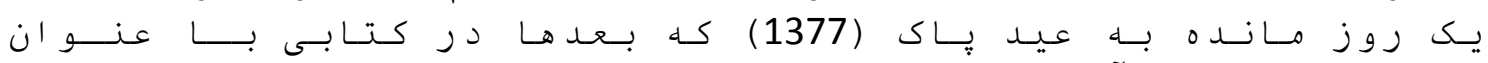

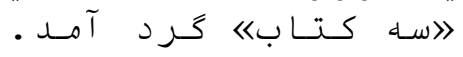

\section{2 ملاصأ آثـار هـيـرز اد}

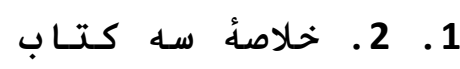

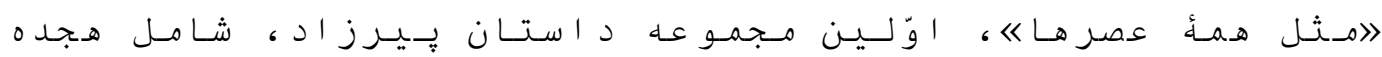

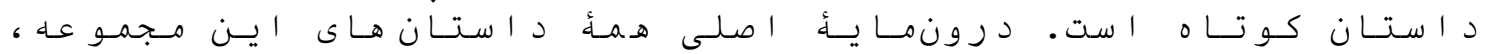

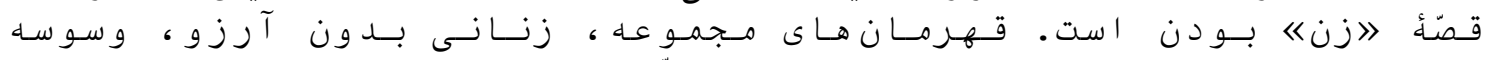

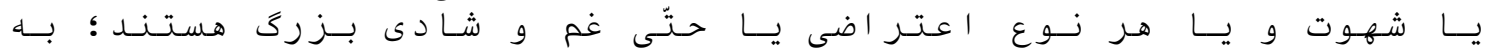

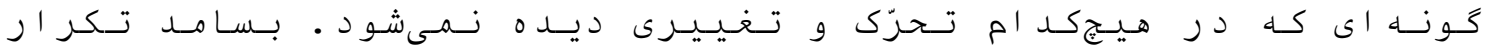

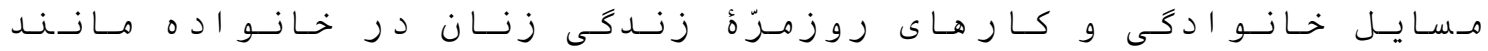




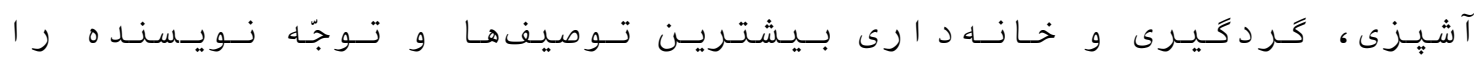

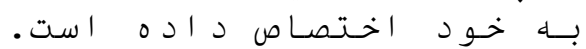

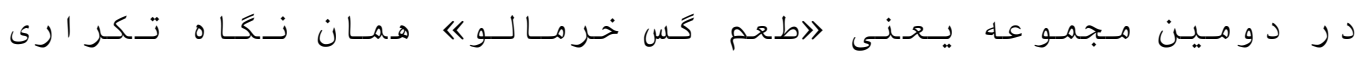

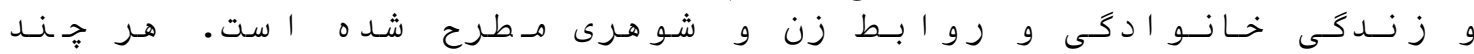

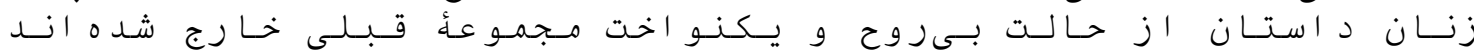

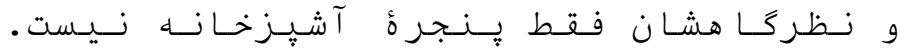

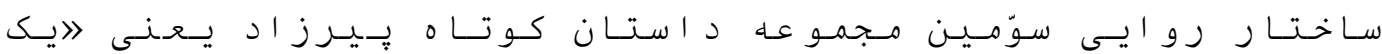

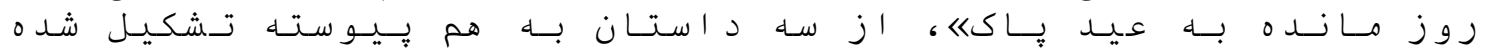

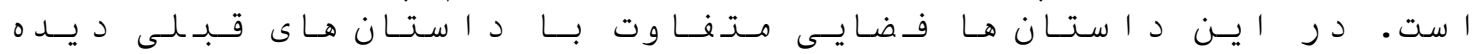

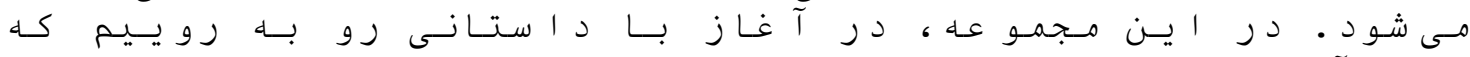

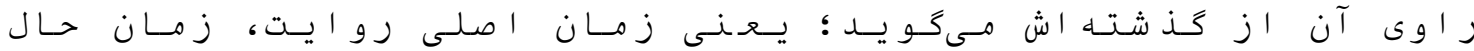

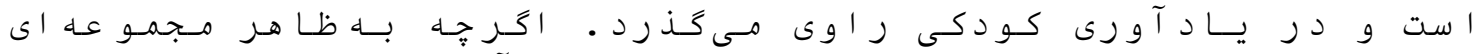

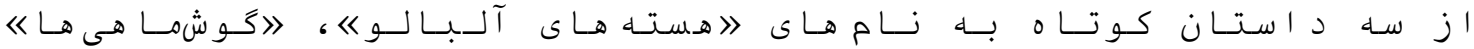

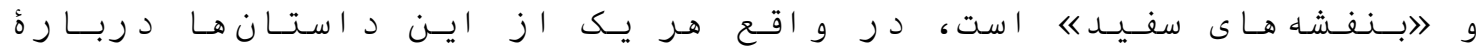

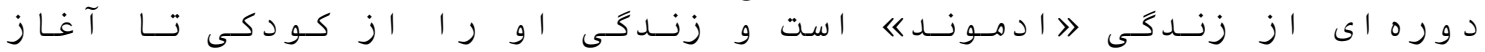

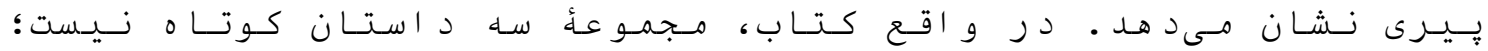

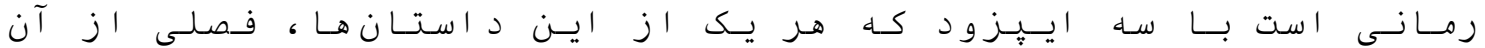

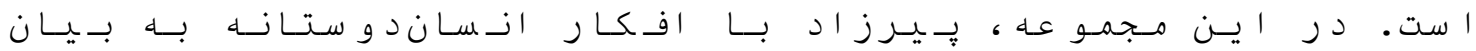

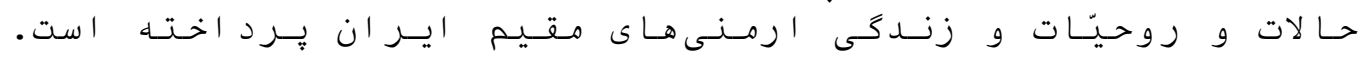

\section{2. 2.}

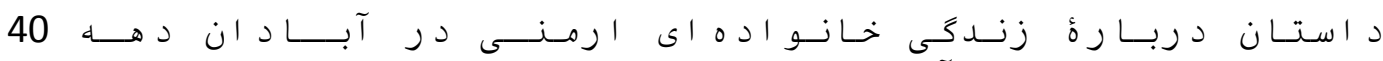

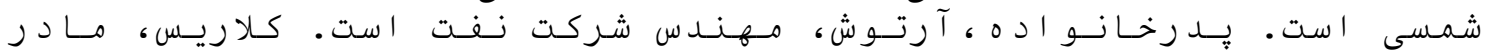

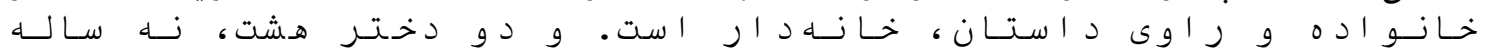

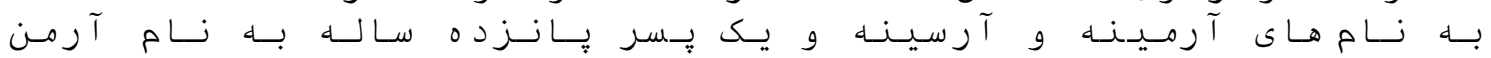

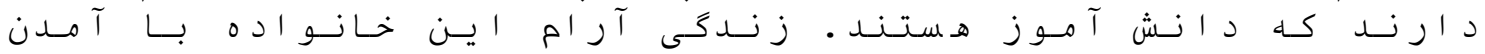

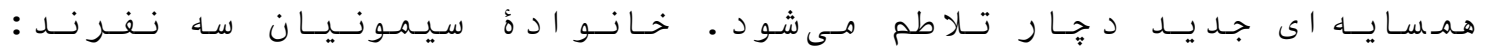

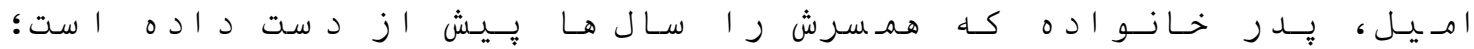

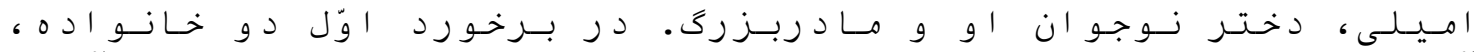

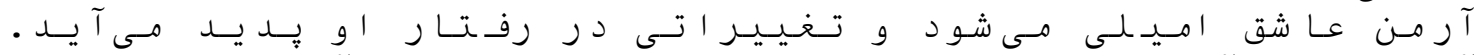

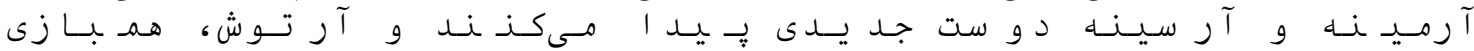

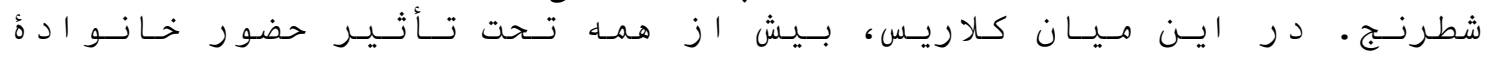

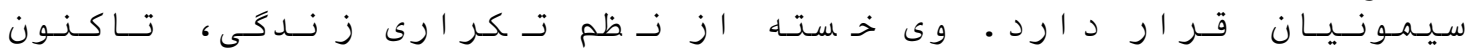

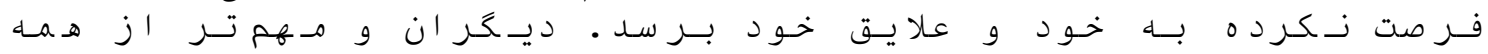

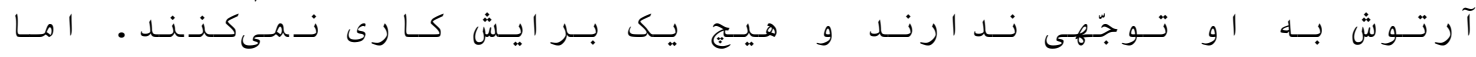

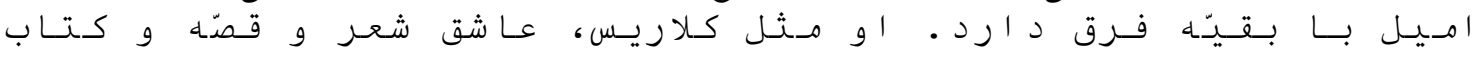

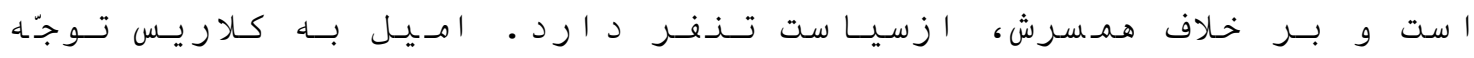

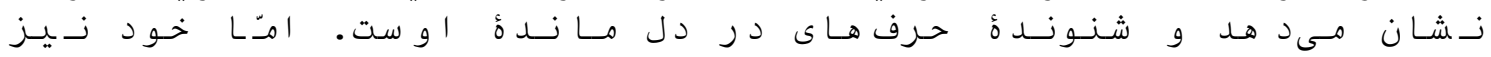

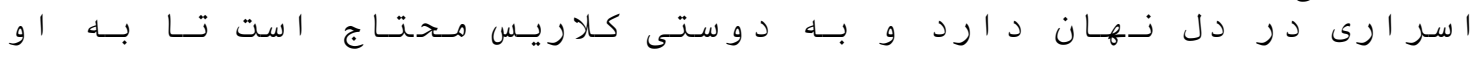

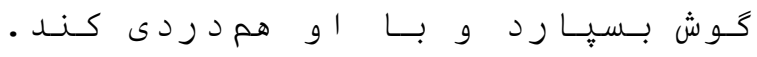

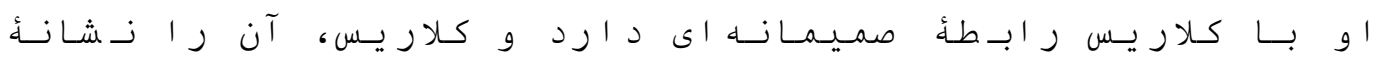

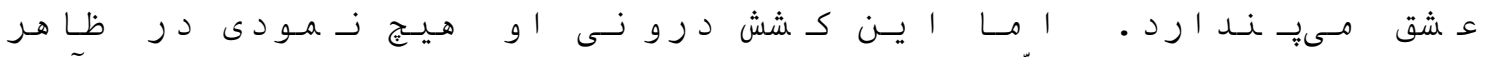

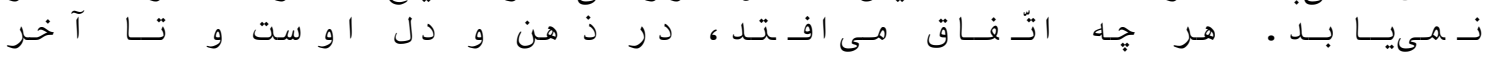

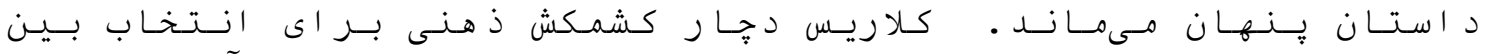

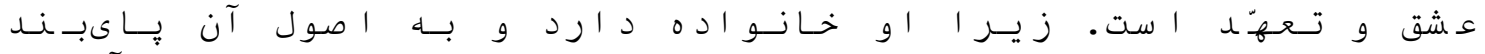

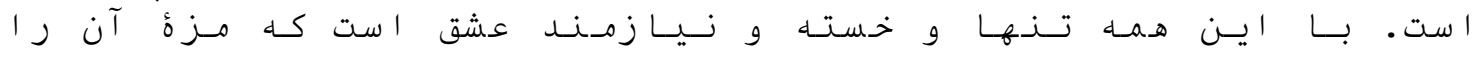

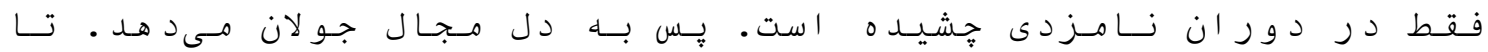




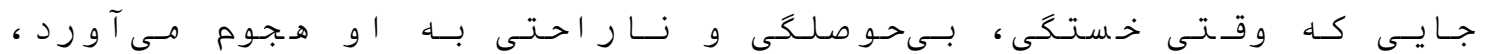

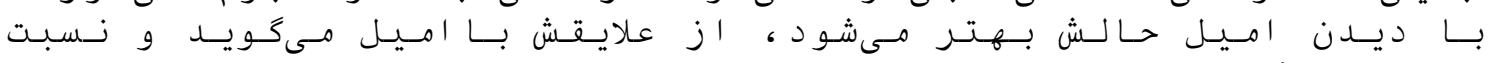

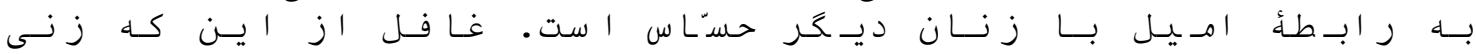

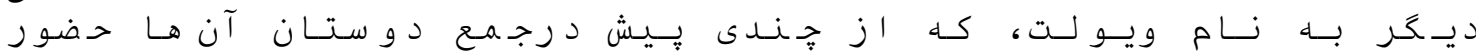

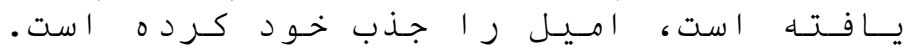

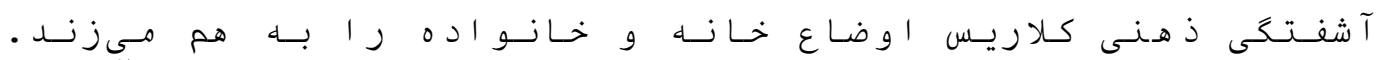

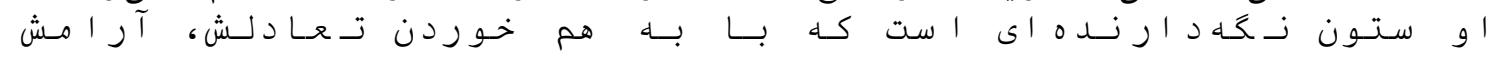

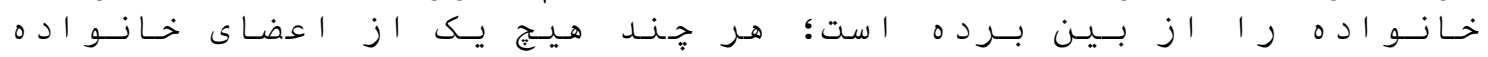

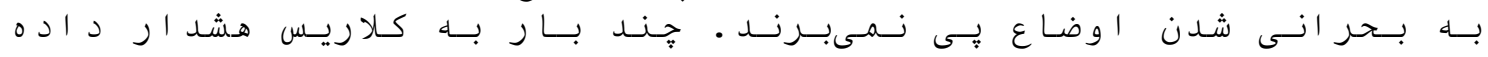

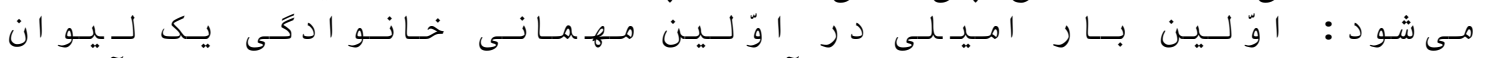

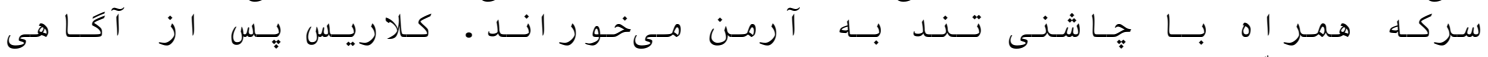

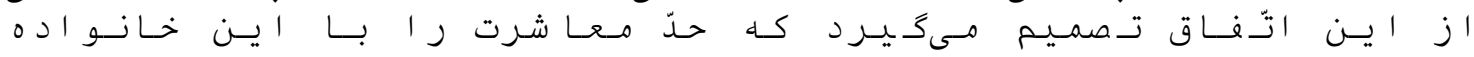

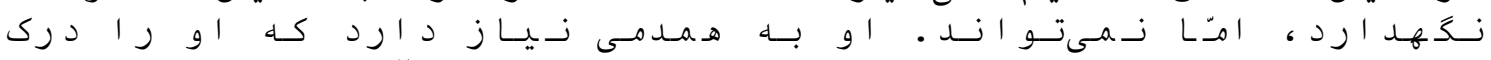

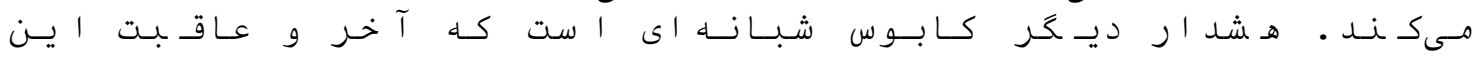

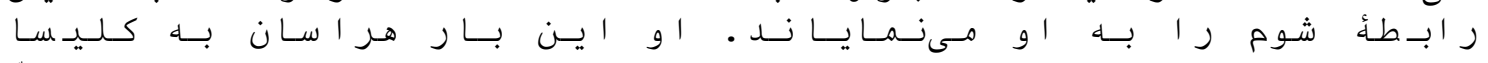

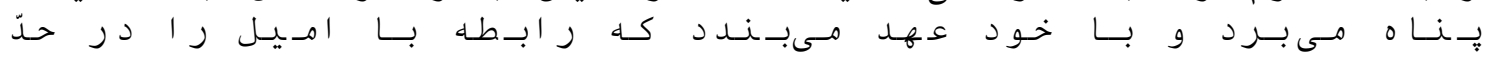

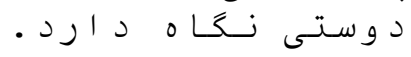

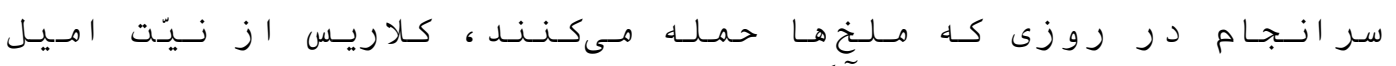

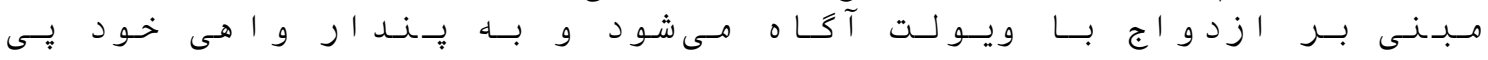

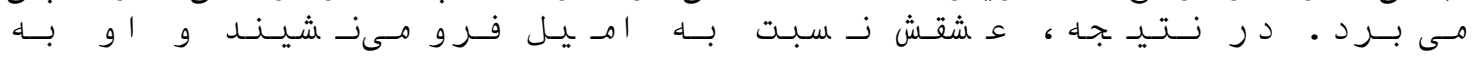

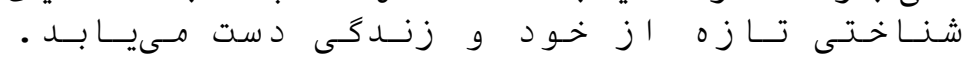

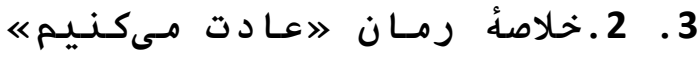

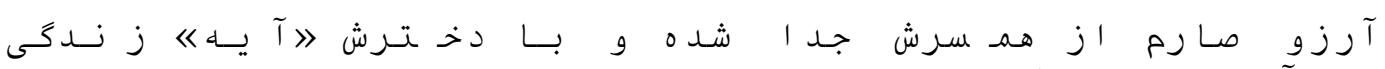

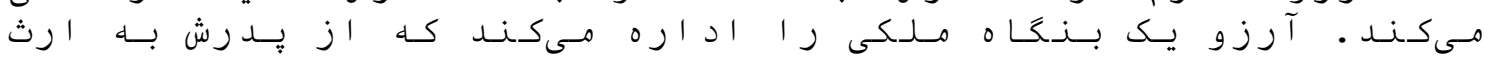

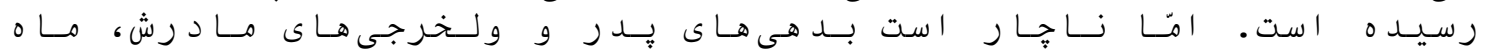

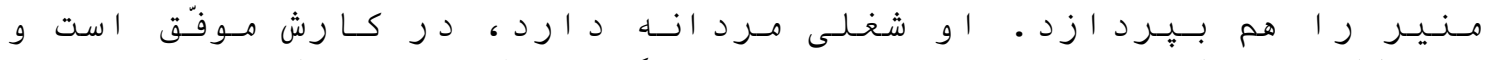

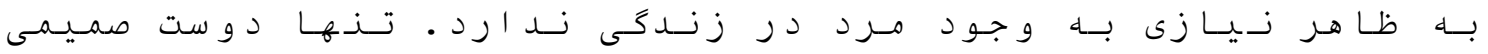

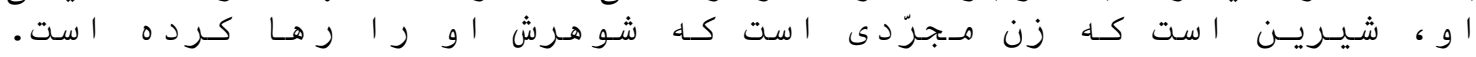

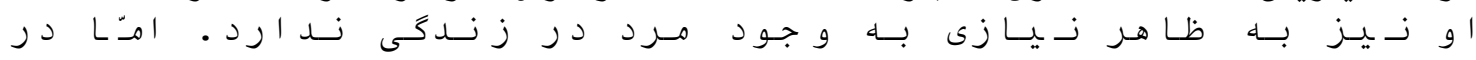

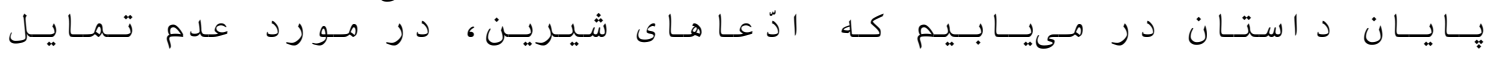

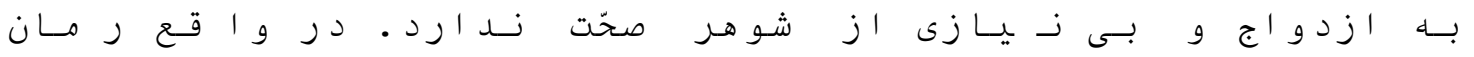

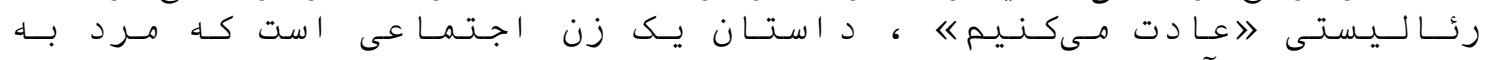

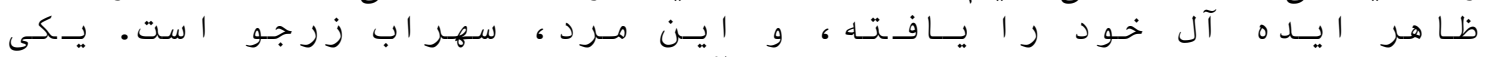

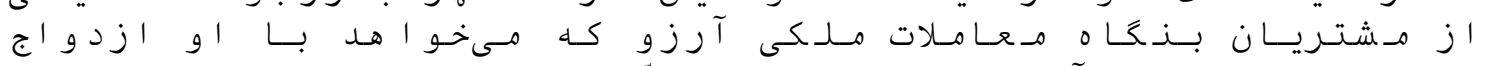

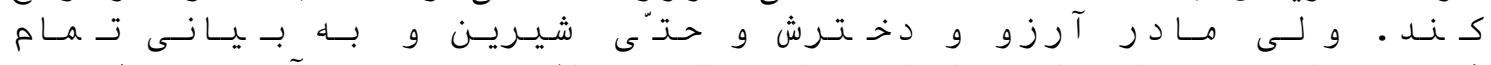

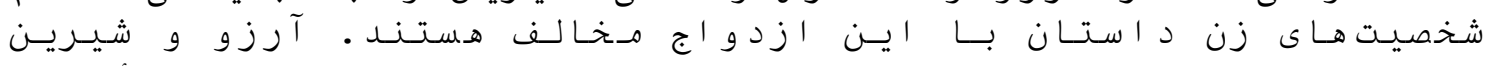

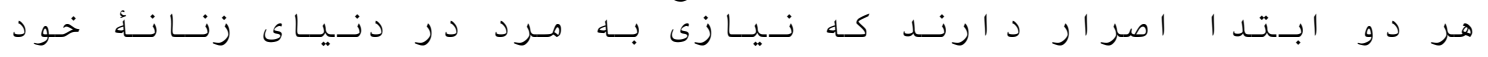

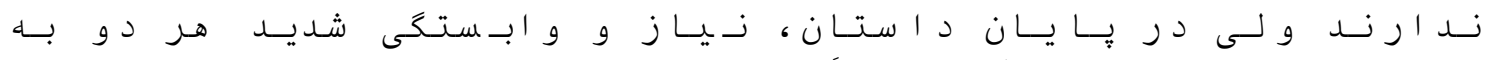

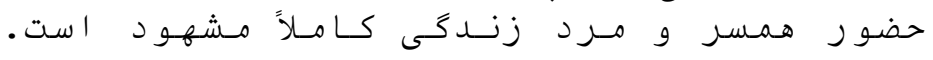

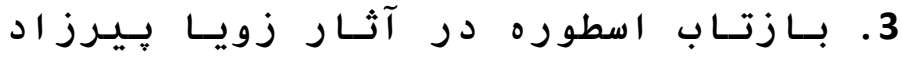

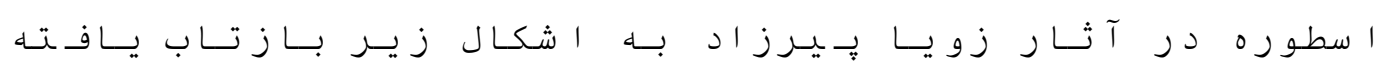

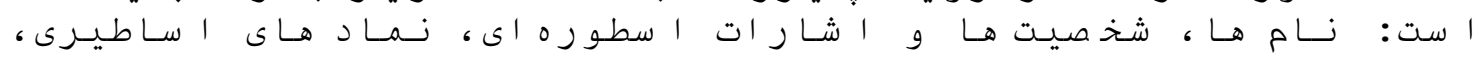

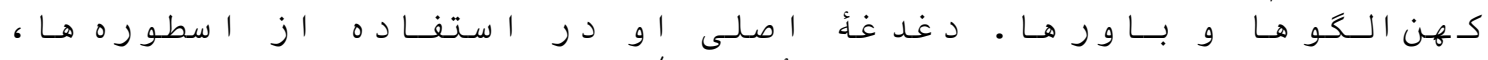

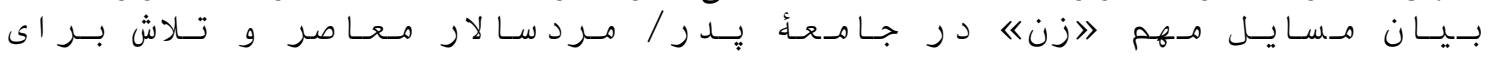

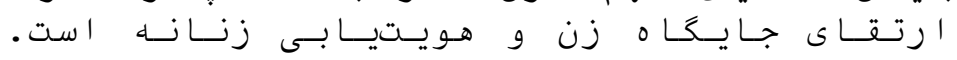




\section{3. نـامهـا ، شخصيـتهـا و اشـار ات اسطور ایى}

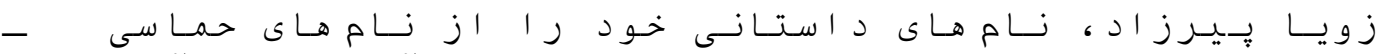

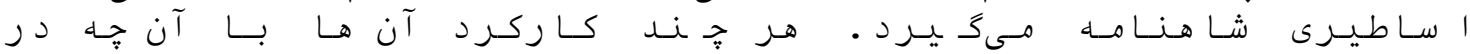

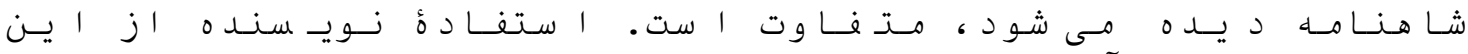

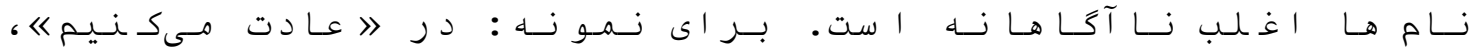

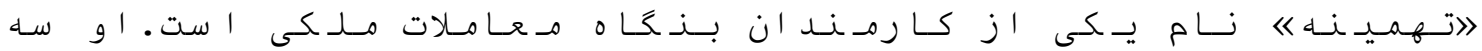

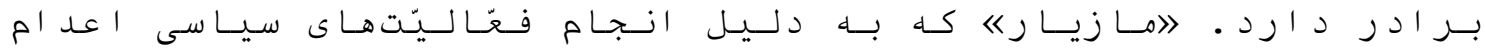

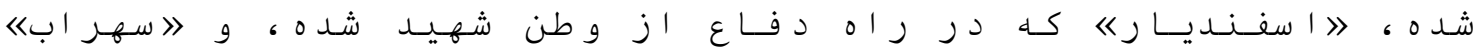

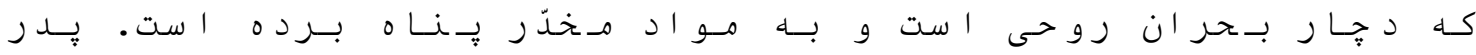

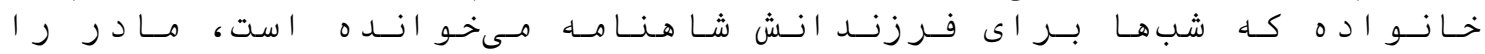

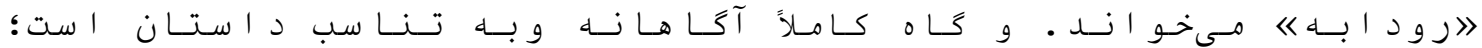

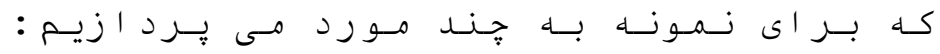

\subsection{3}

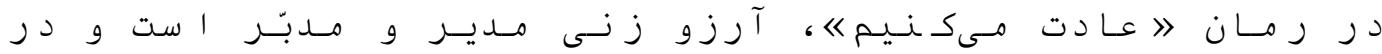

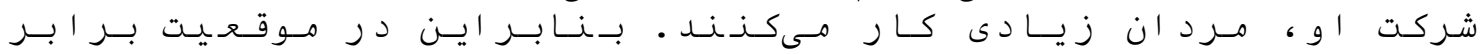

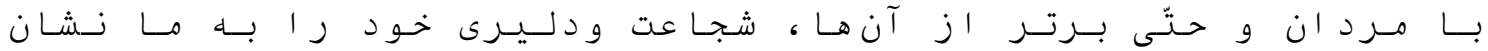

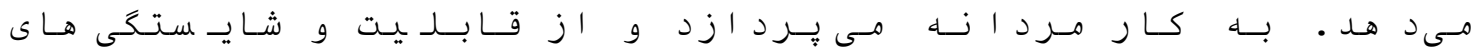

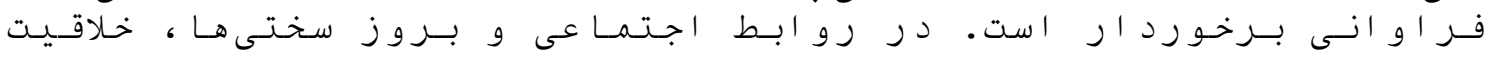

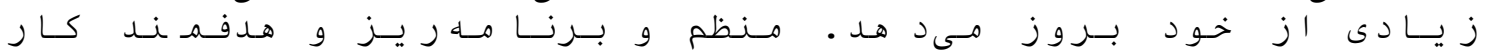

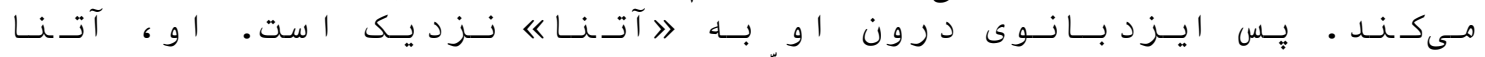

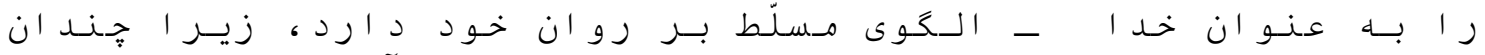

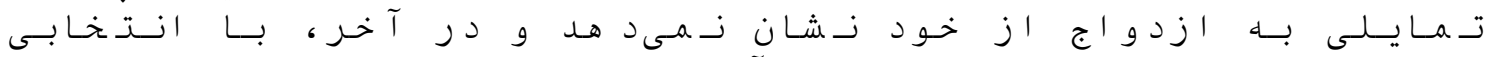

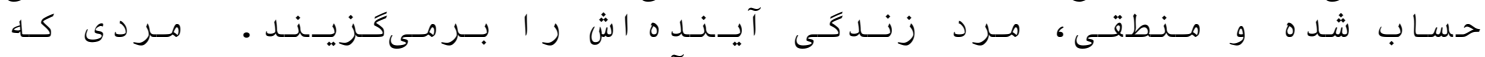

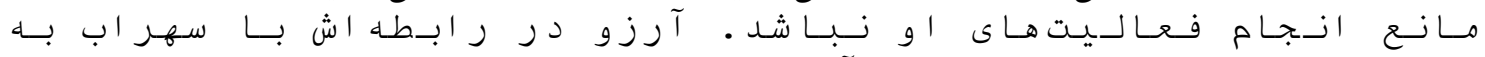

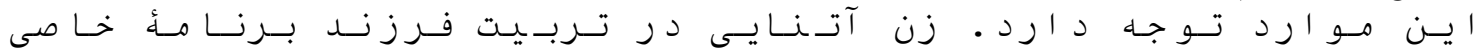

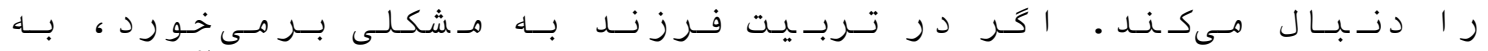

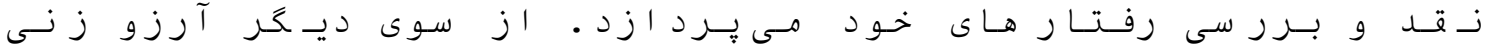

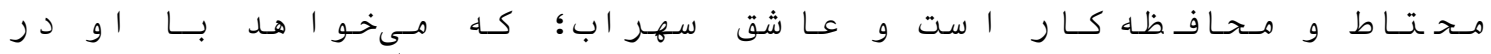

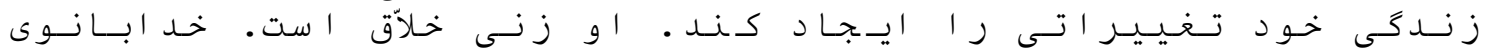

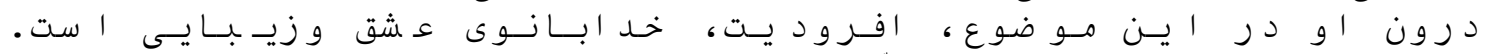

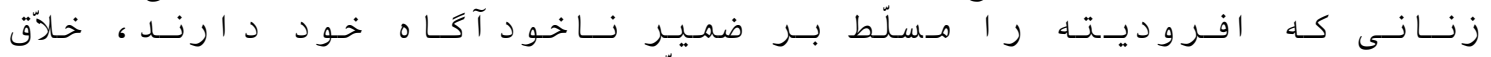

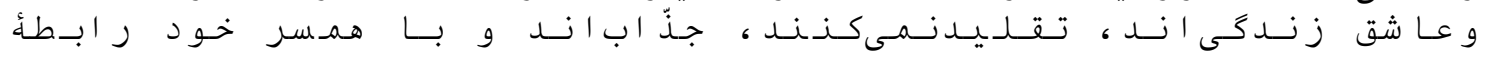

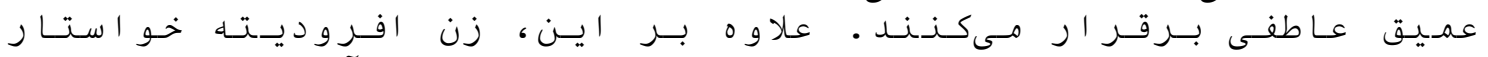

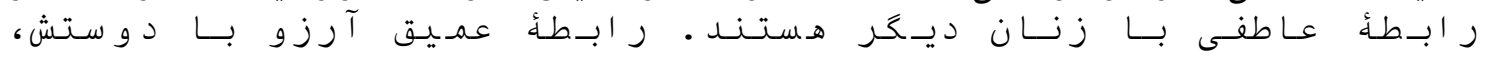

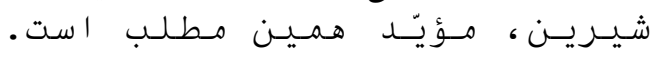

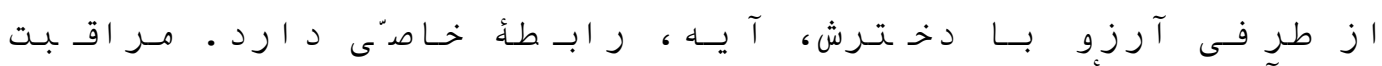

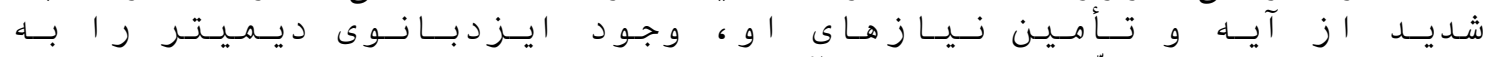

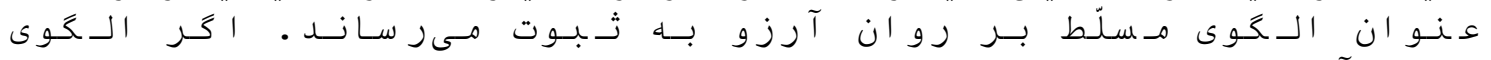

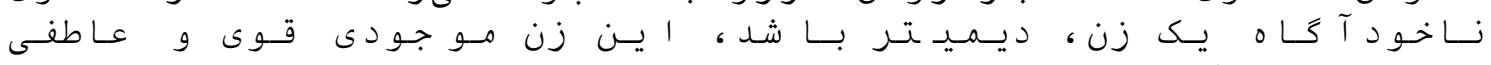

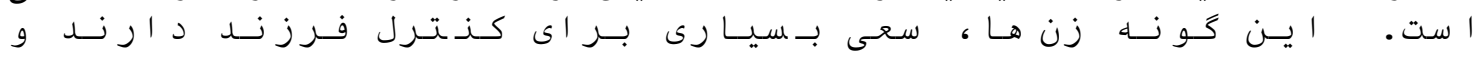

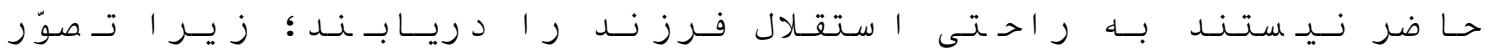

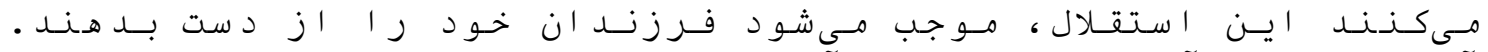

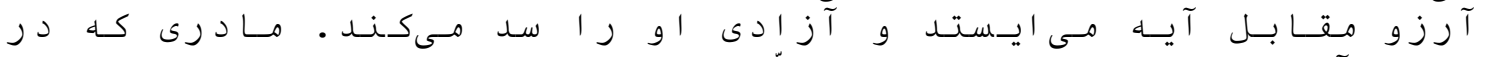

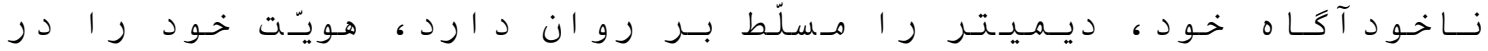




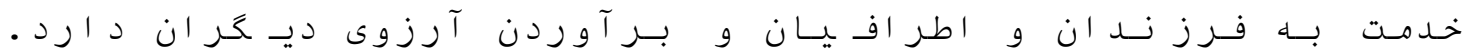

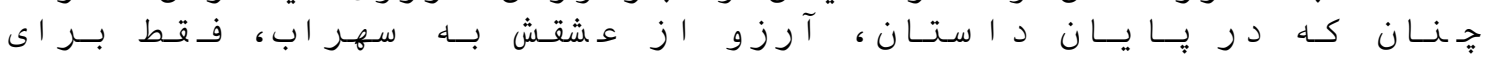

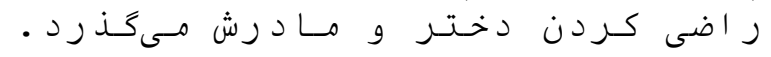

\section{2}

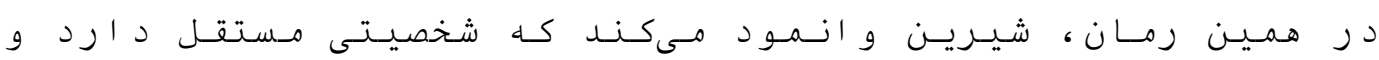

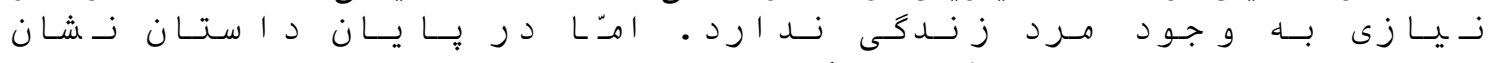

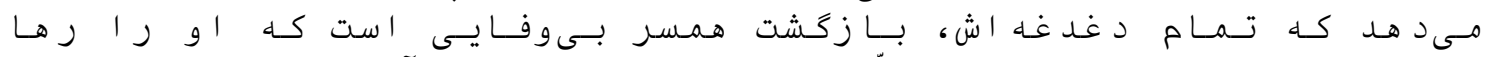

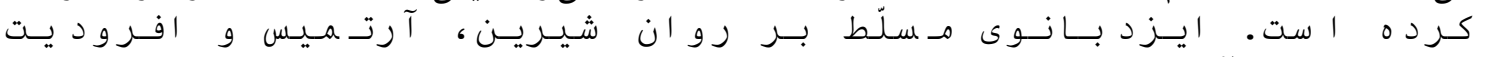

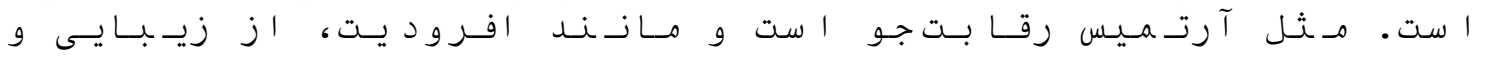

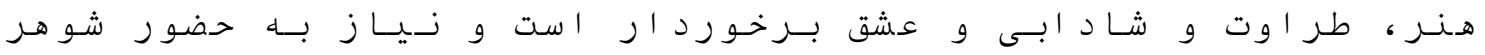

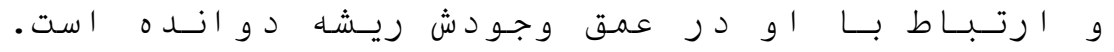

\section{3}

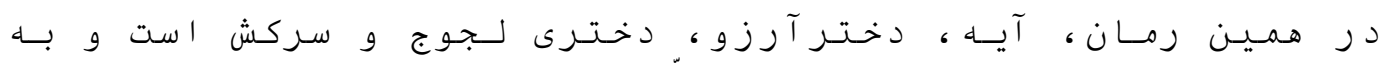

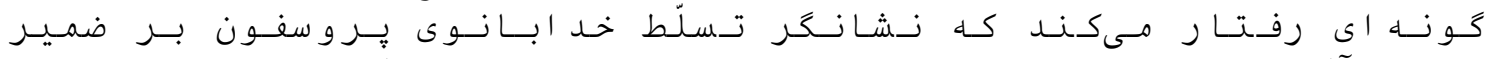

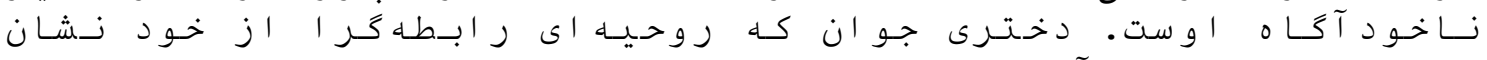

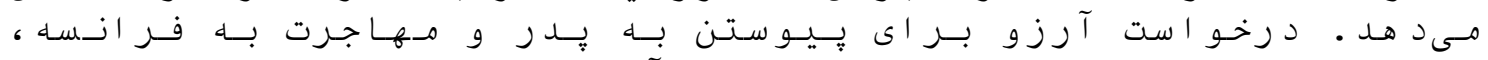

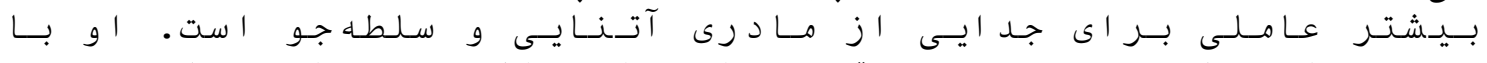

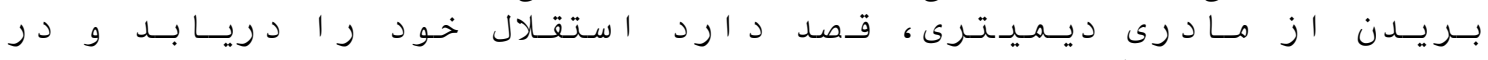

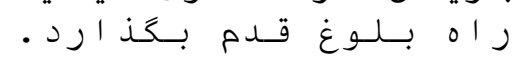

\section{( ب.1}

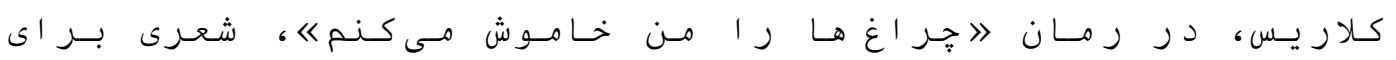

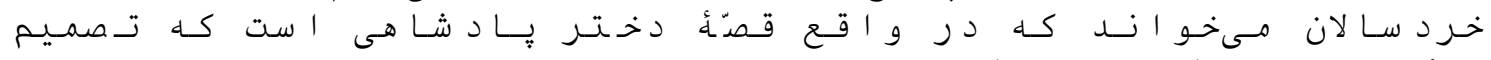

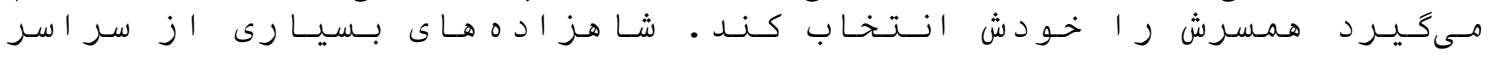

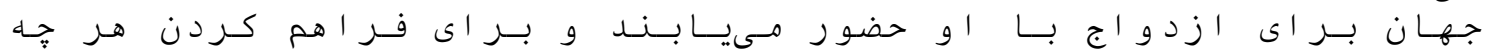

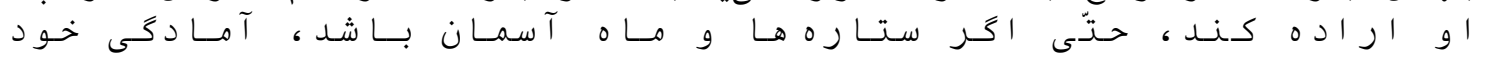

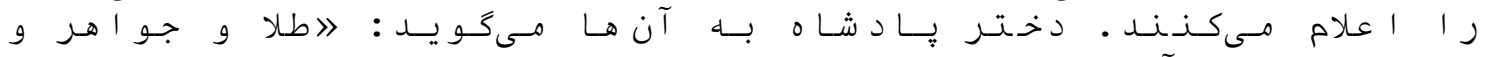

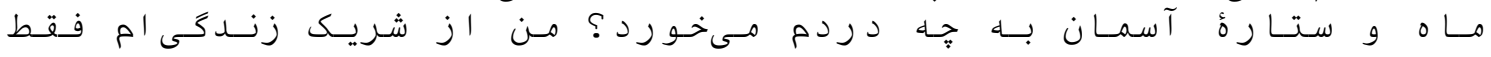

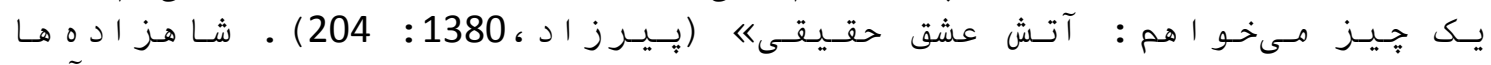

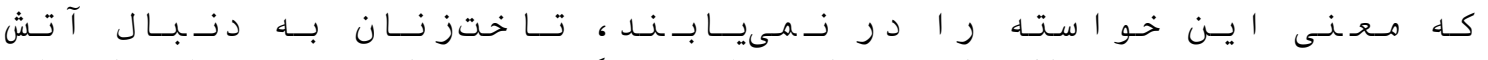

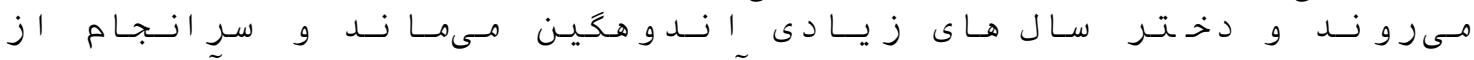

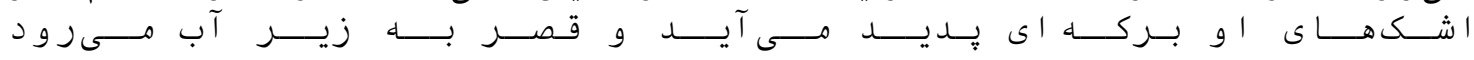

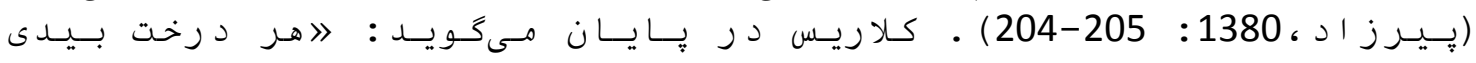

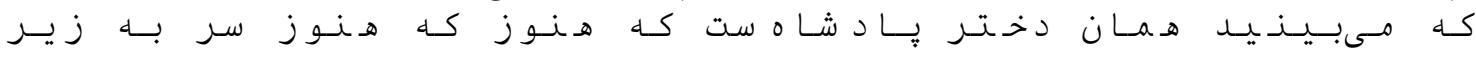

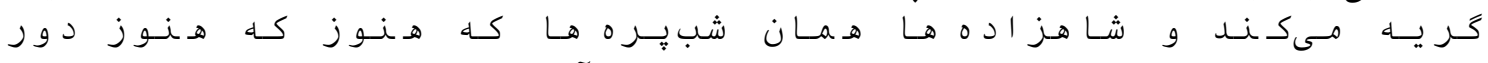

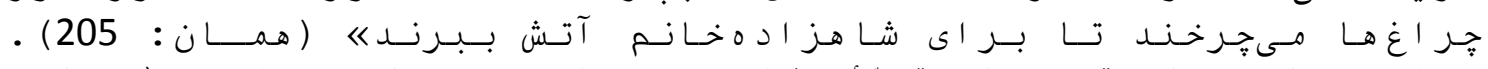

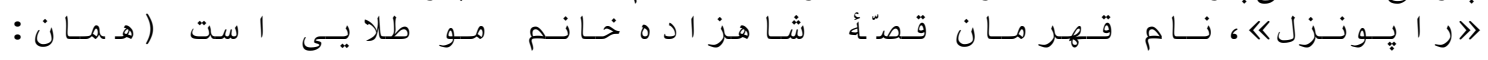

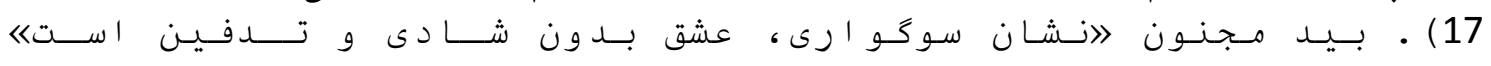
. (كـويـر ، 1379)

2. 3.

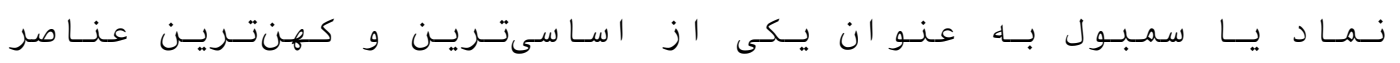

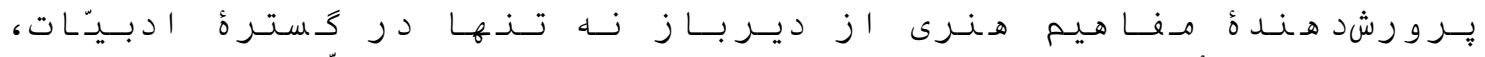

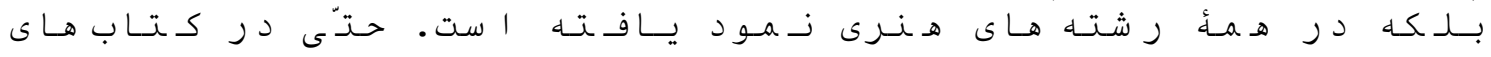




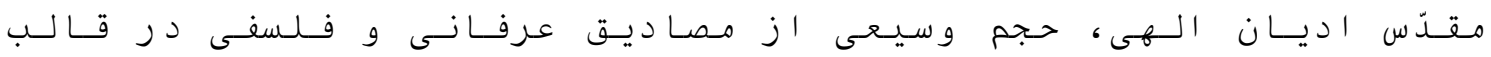

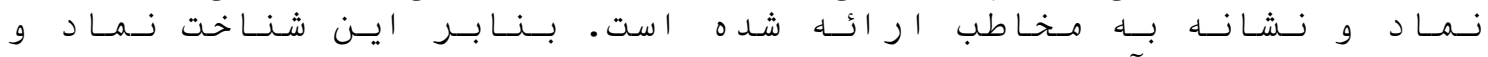

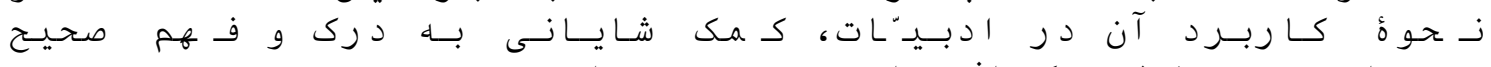

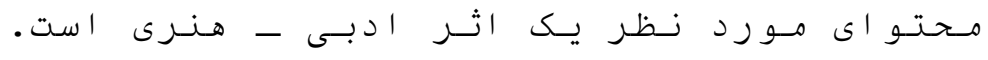

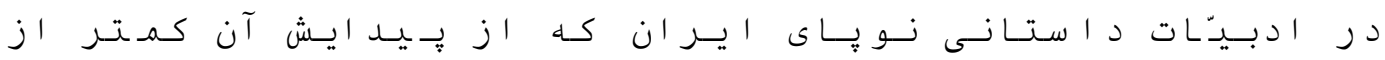

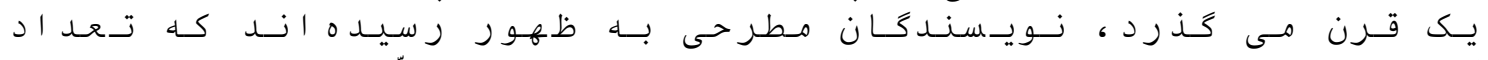

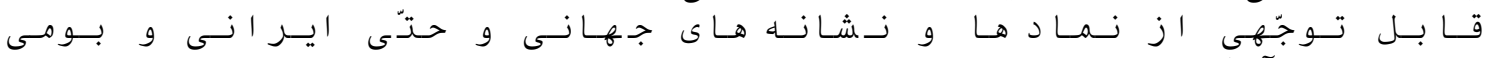

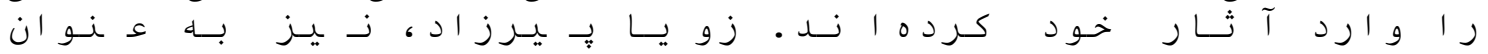

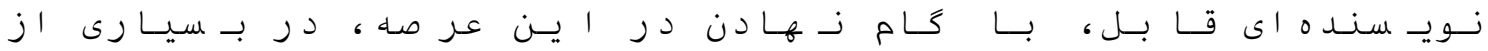

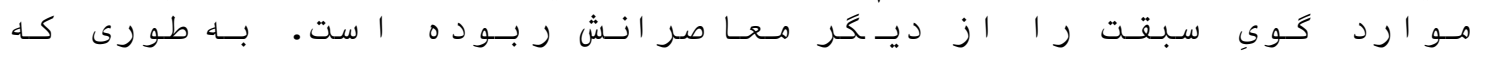

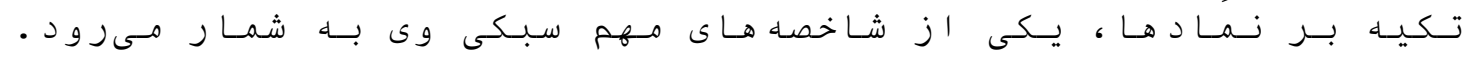

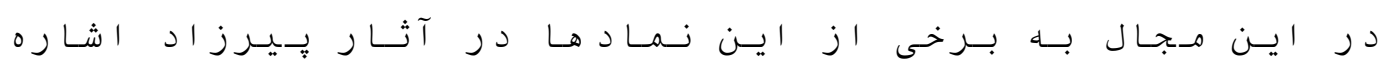
مسى د د : مس

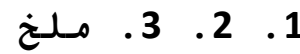

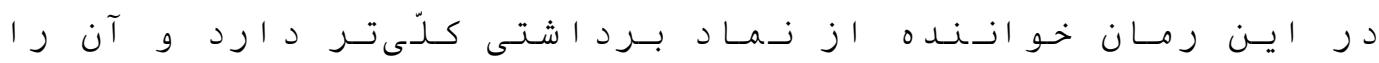

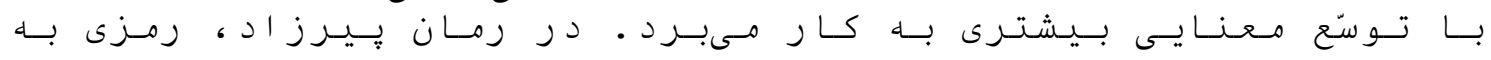

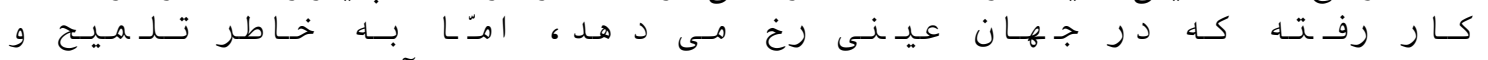

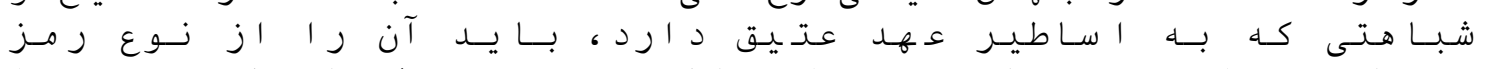

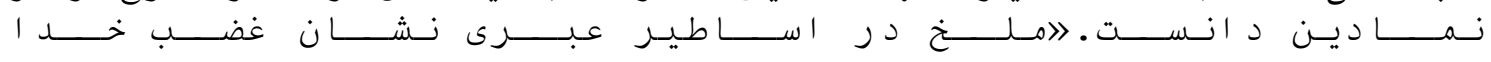

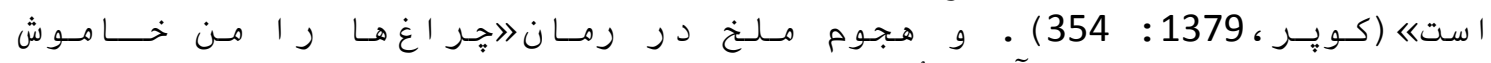

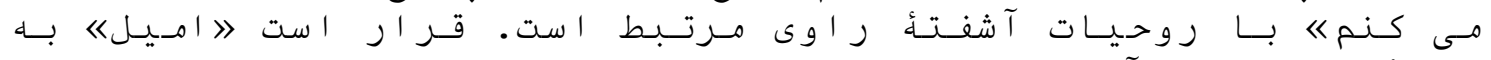

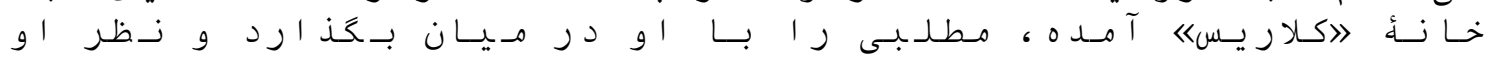

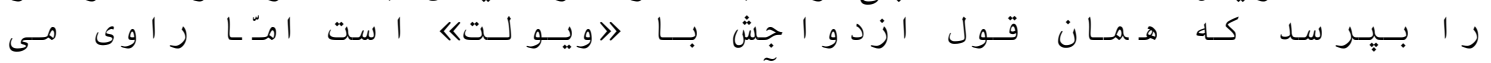

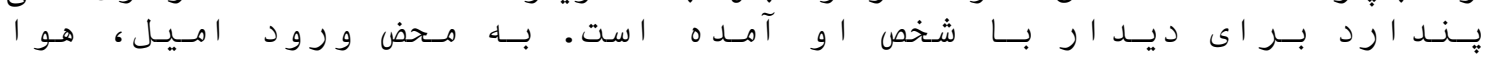

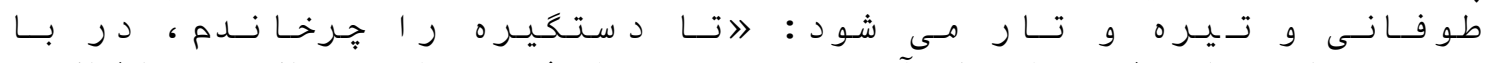

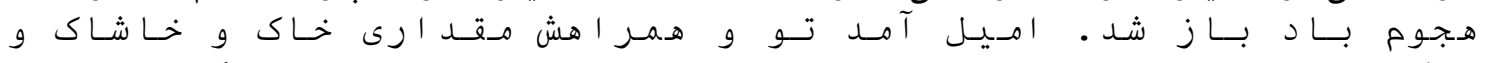

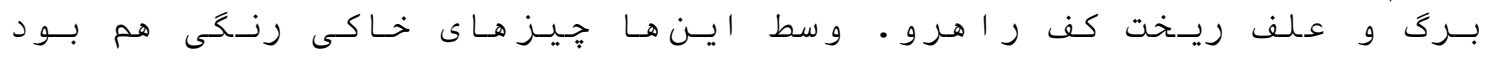

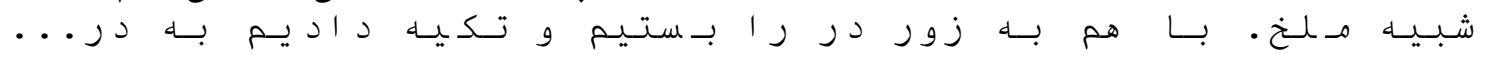

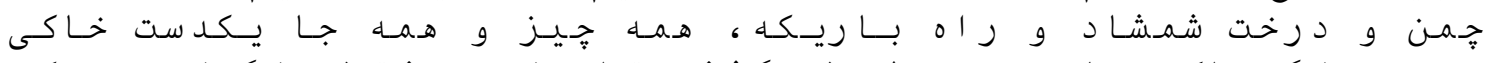

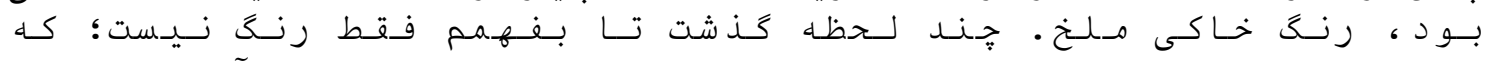

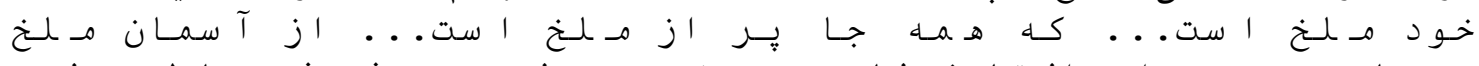

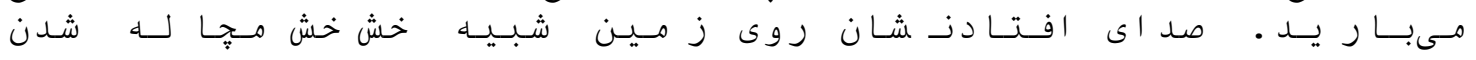

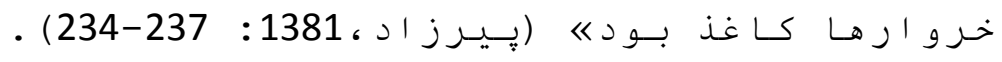

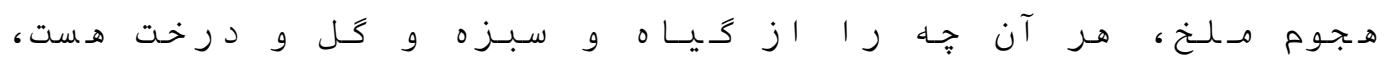

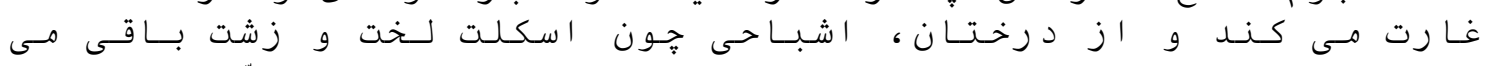

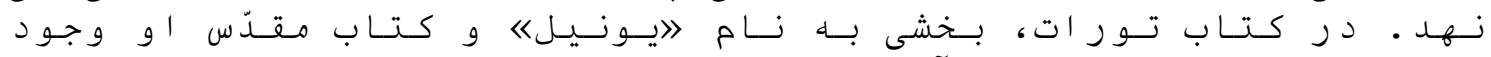

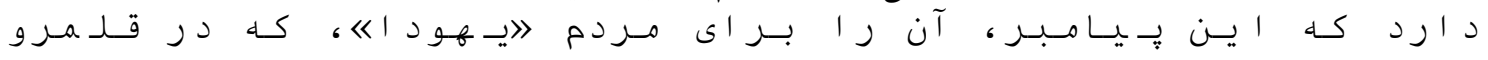

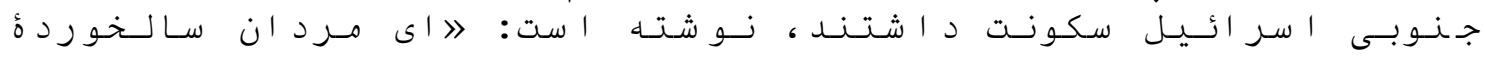

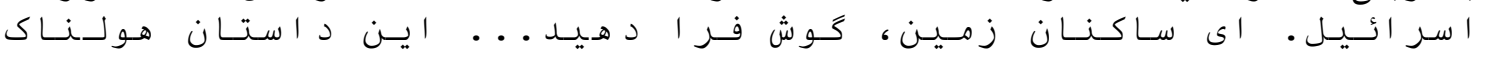

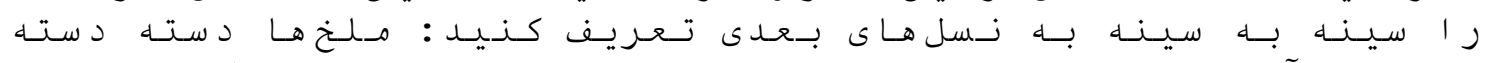

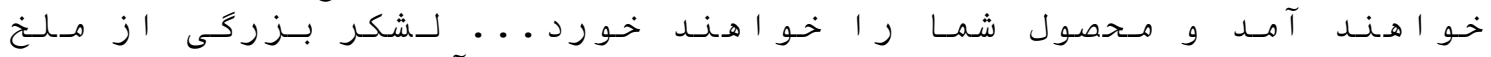

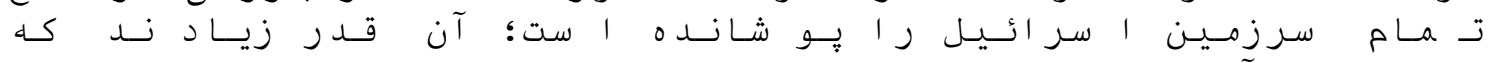

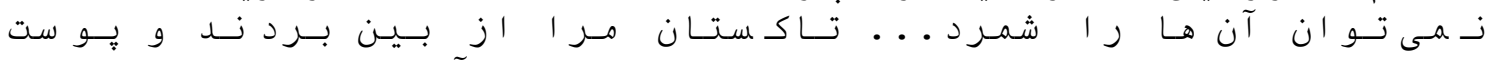

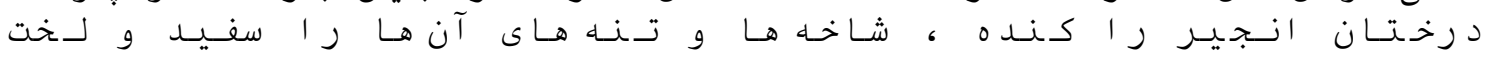

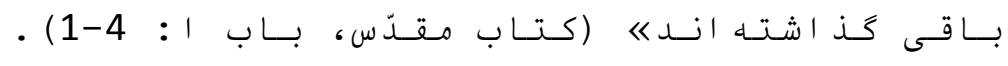




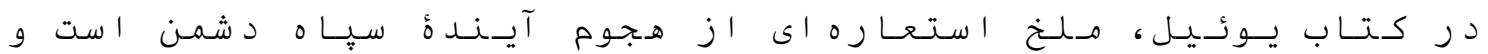

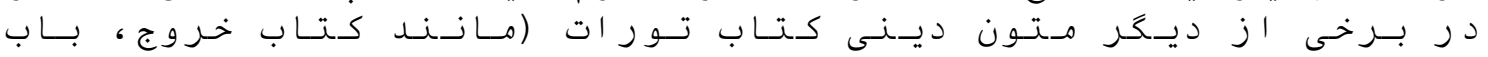

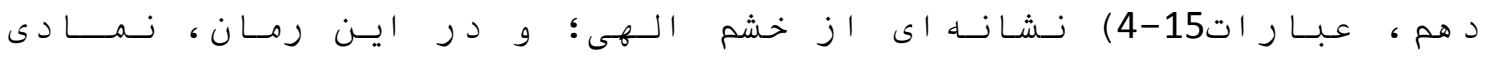

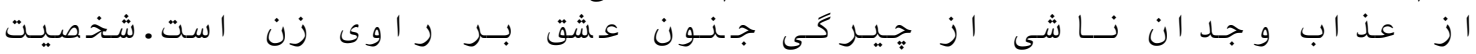

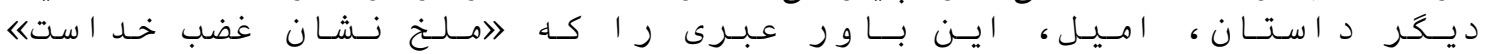

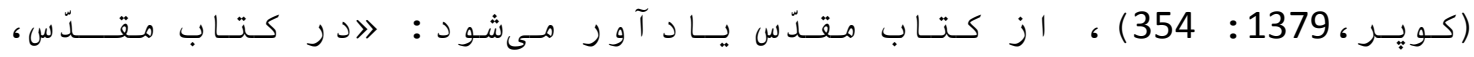

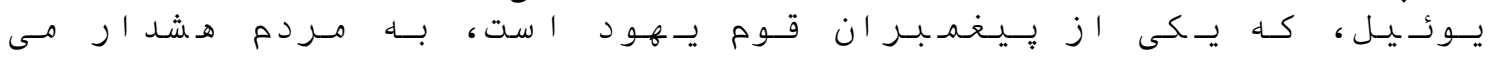

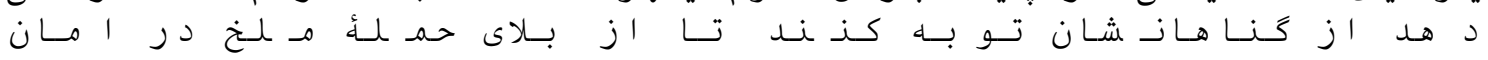

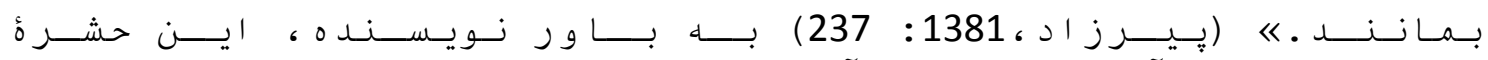

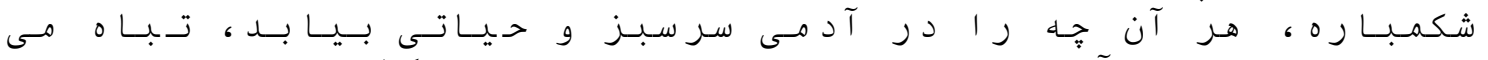

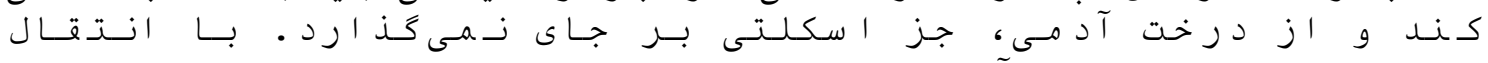

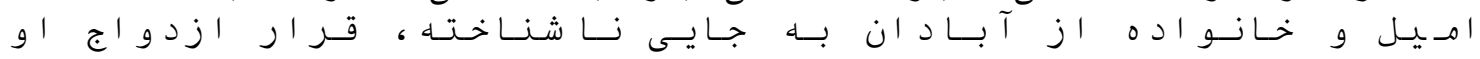

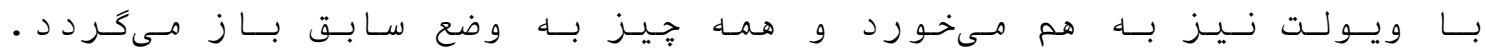

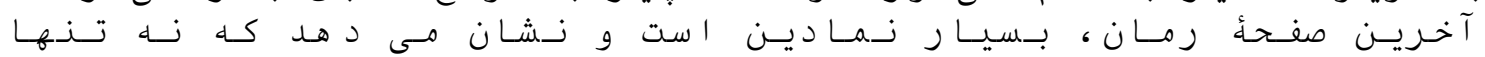

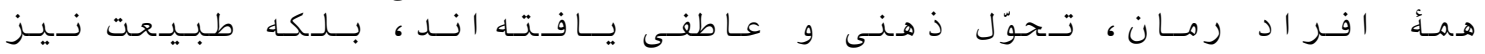

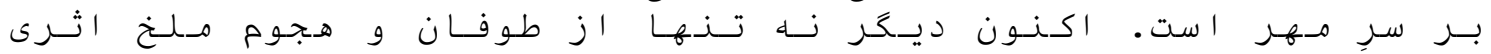

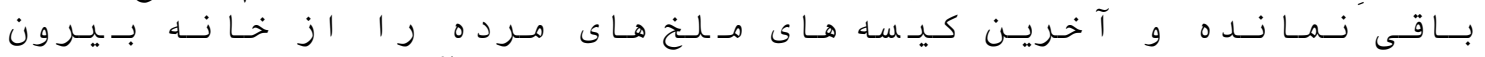

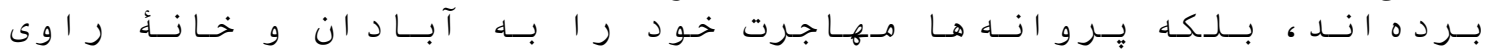

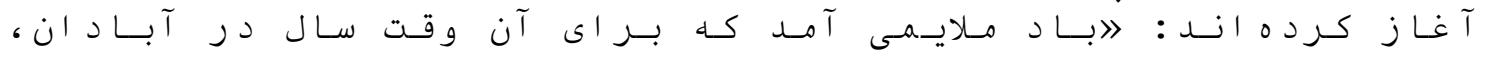

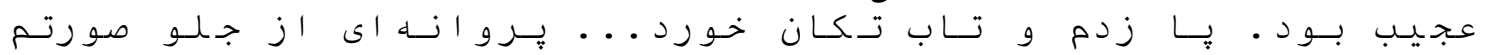

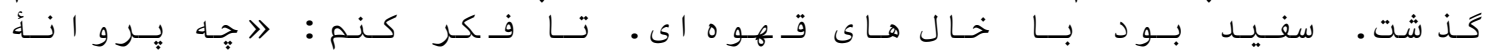

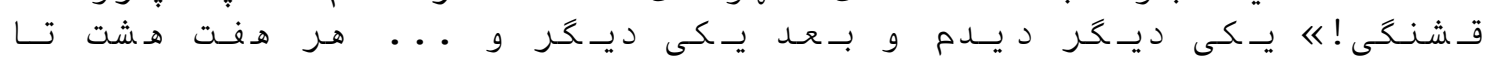

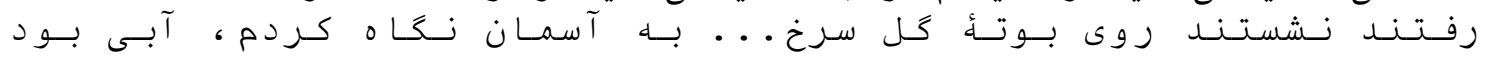

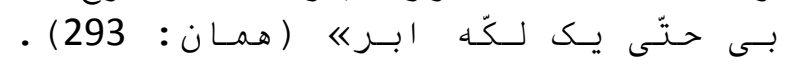

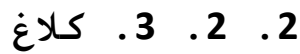

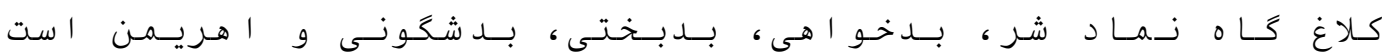

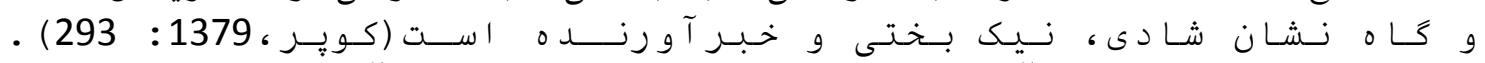

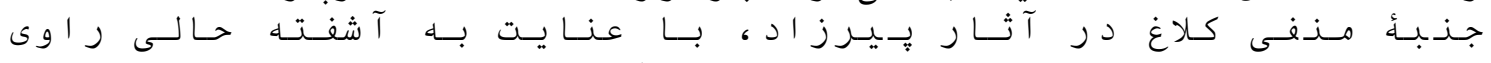

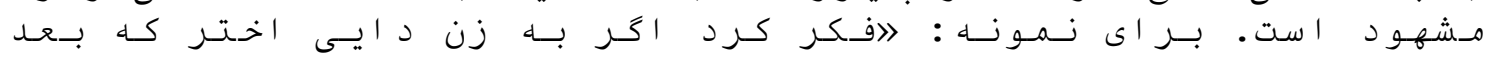

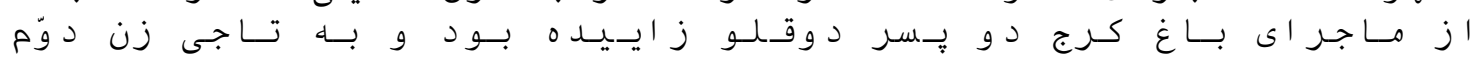

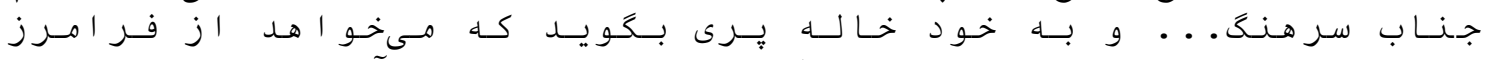

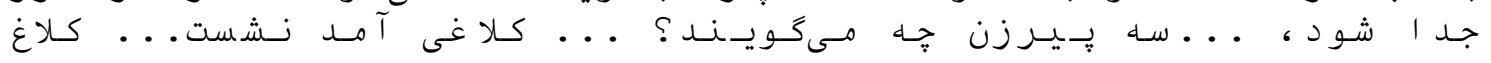

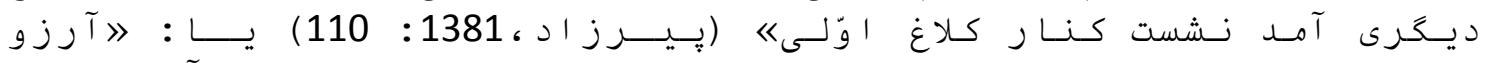

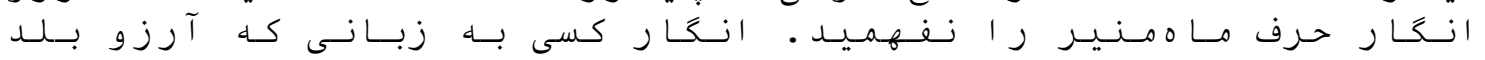

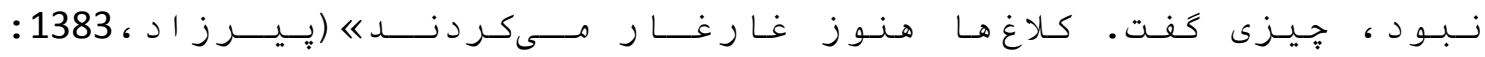

\section{2. 3. قـوربـاغه}

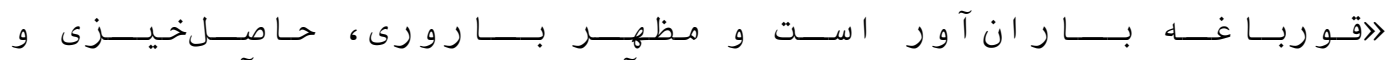

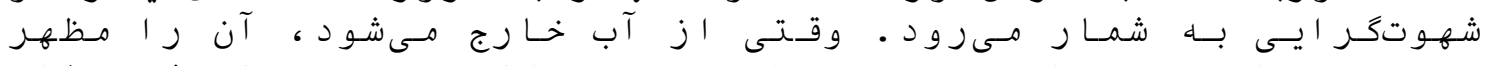

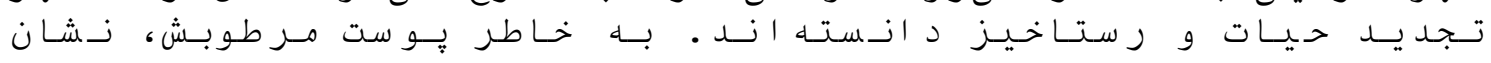

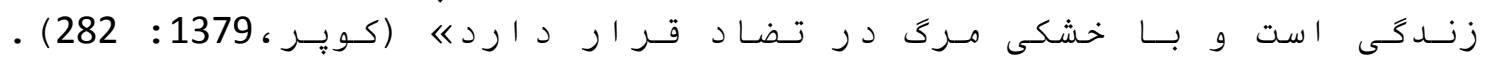

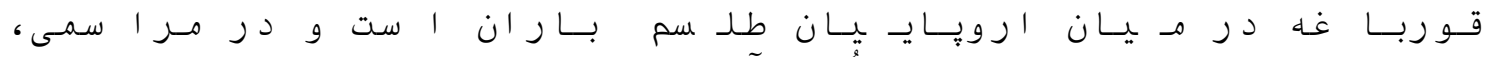

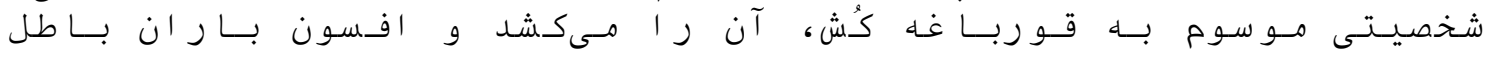

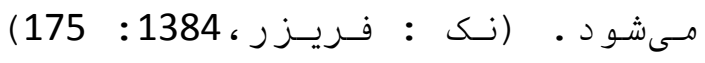




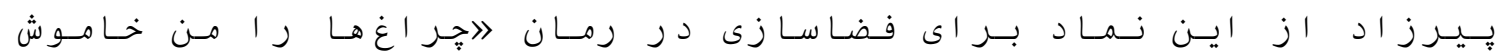

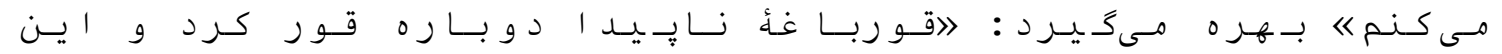

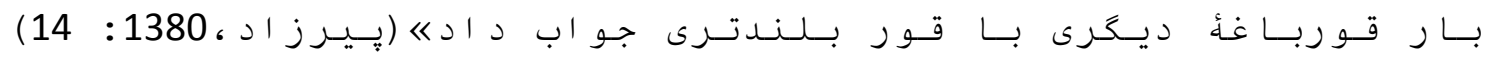

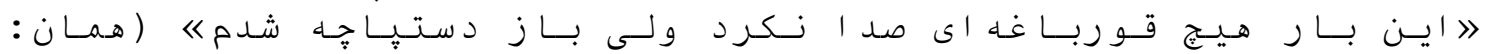

\section{(4}

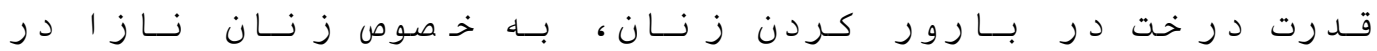

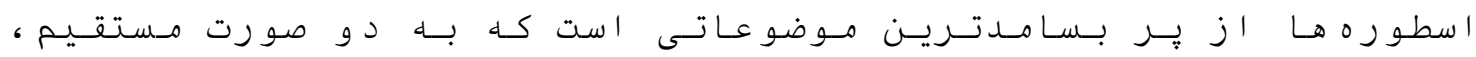

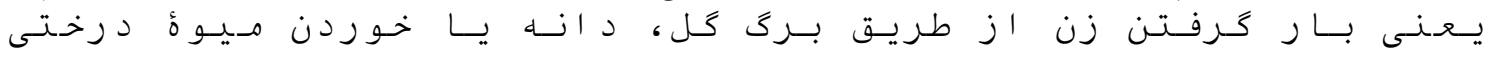

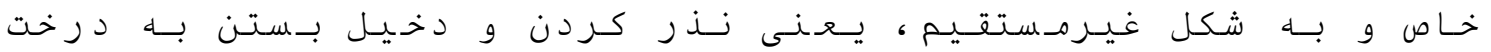

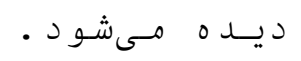

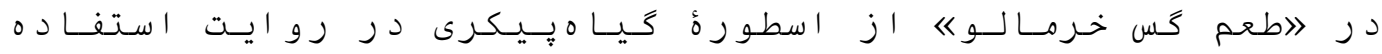

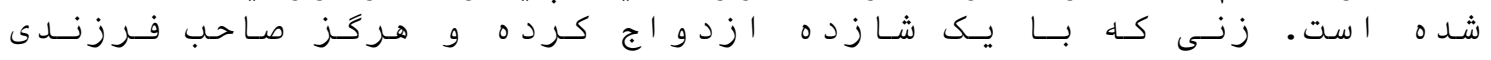

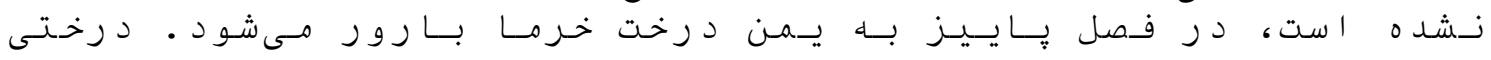

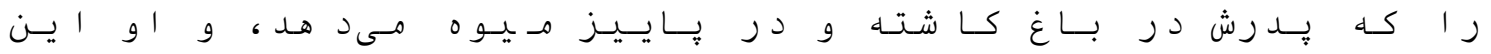

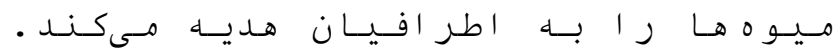

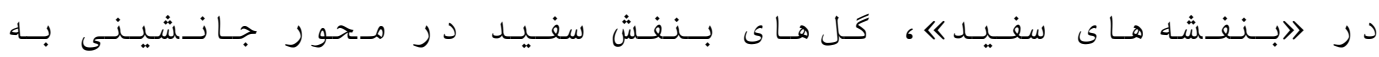

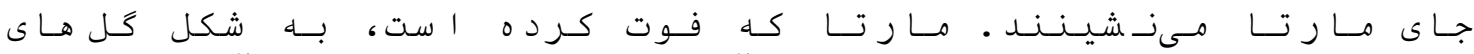

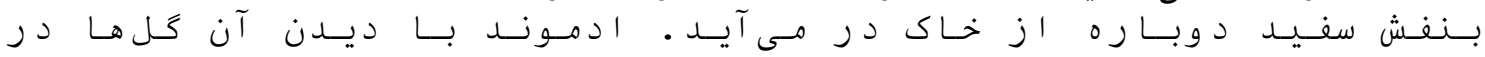

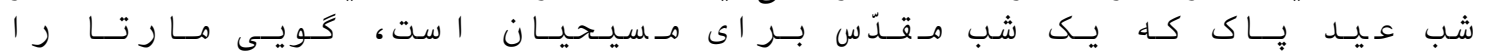

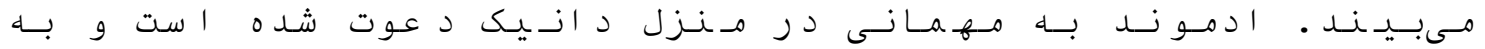

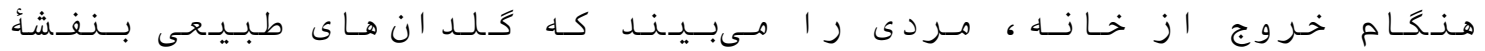

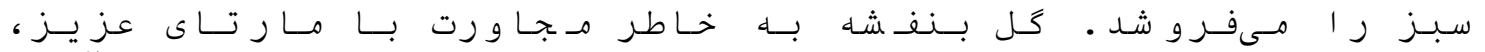

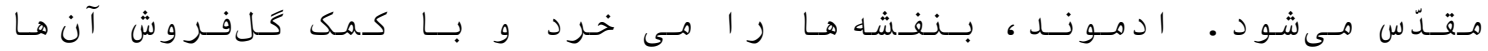

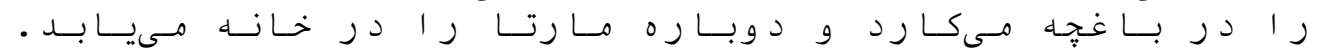

\section{5}

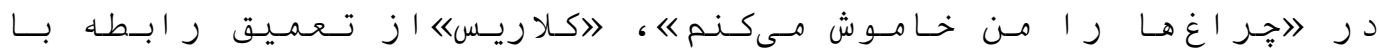

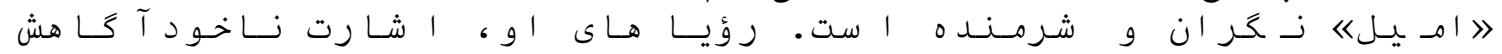

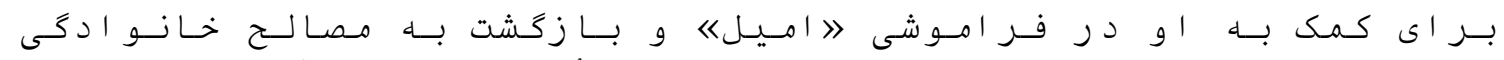

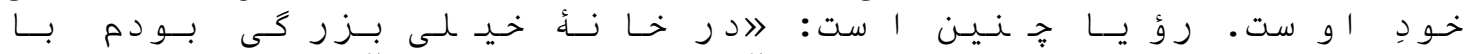

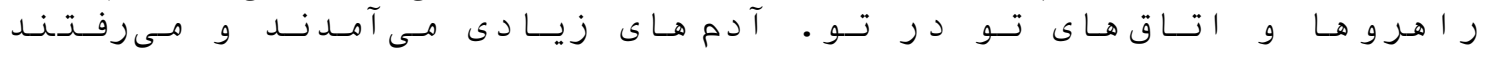

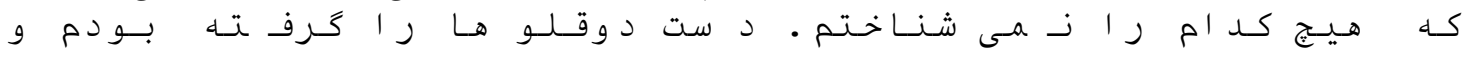

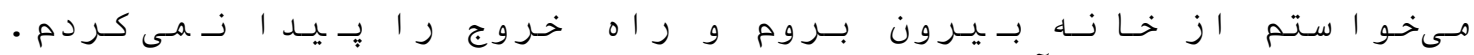

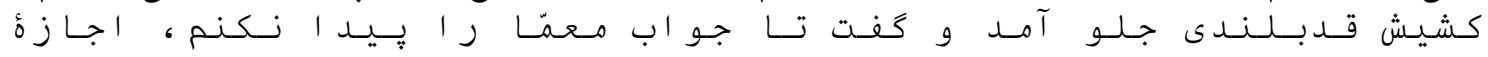

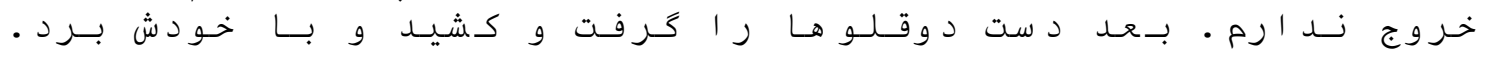

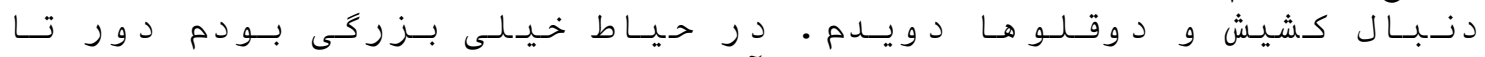

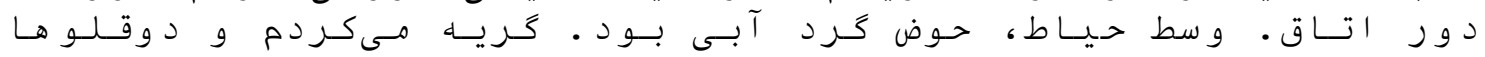

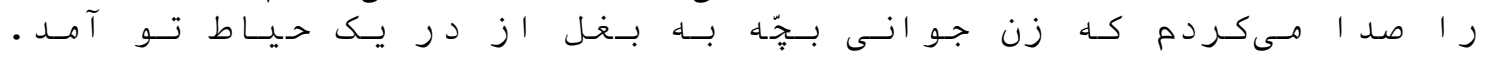

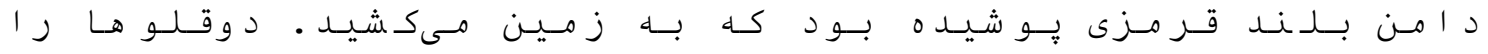

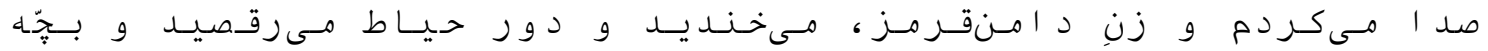

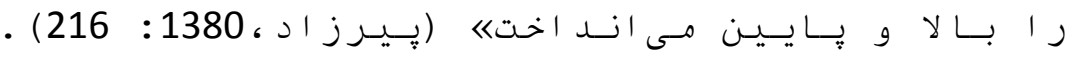

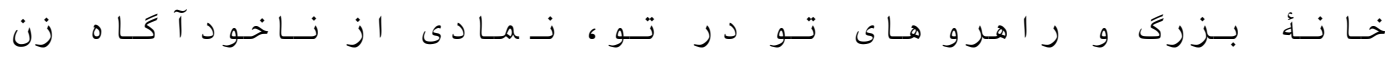

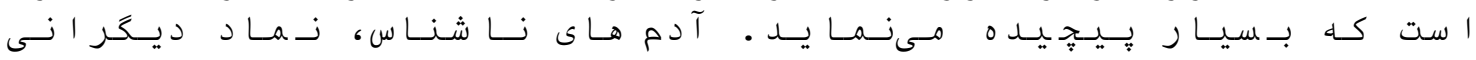

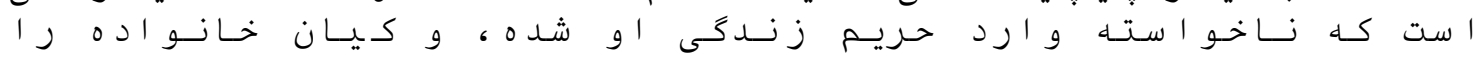




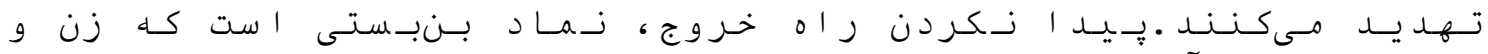

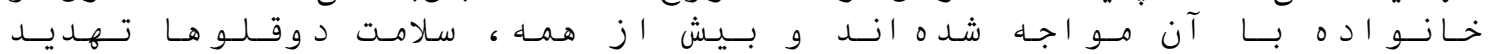

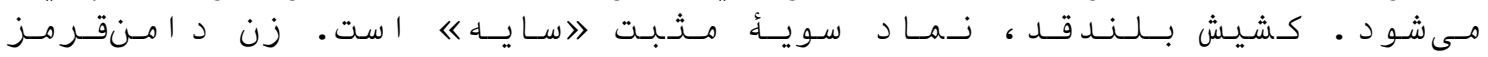

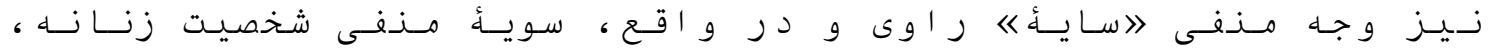

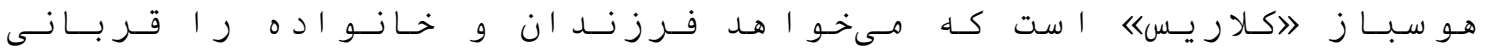

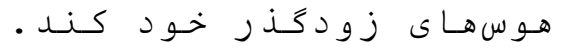

\section{$\begin{array}{lllll} & \\ & & \end{array}$}

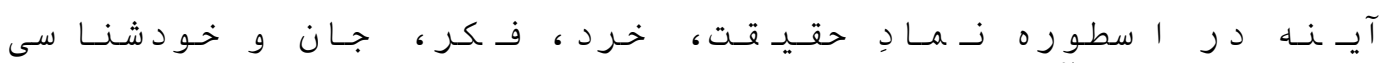

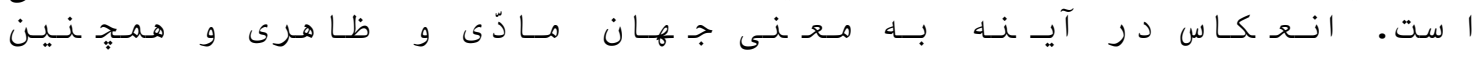

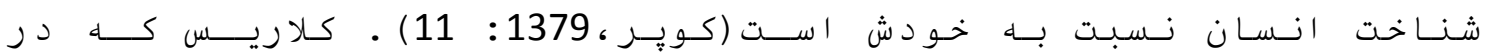

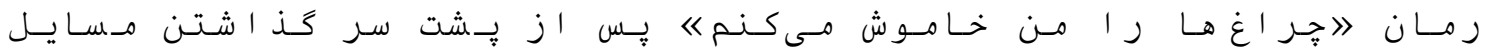

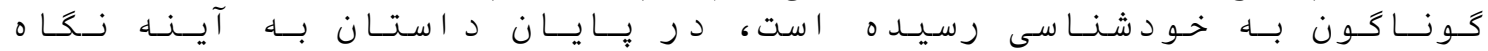

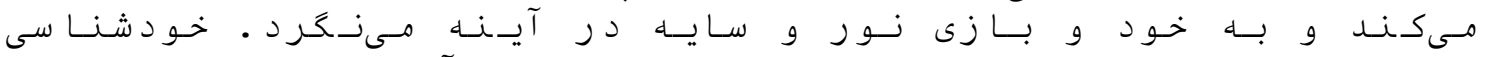

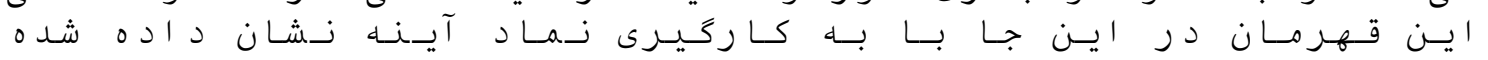

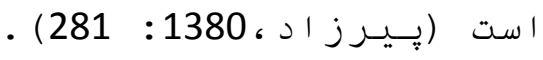

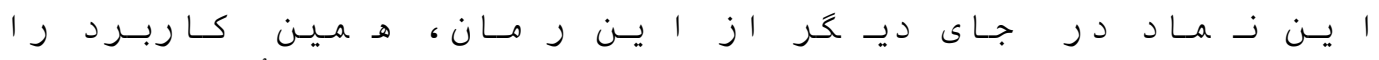

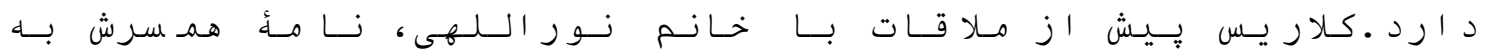

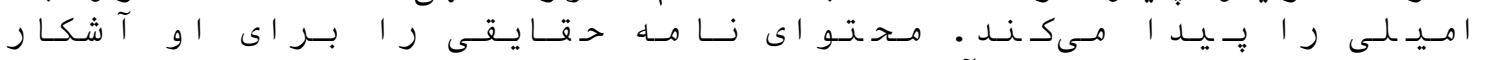

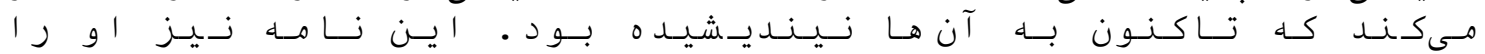

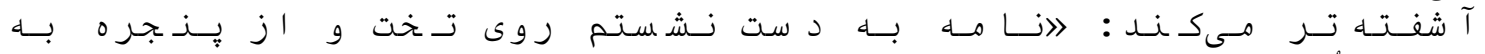

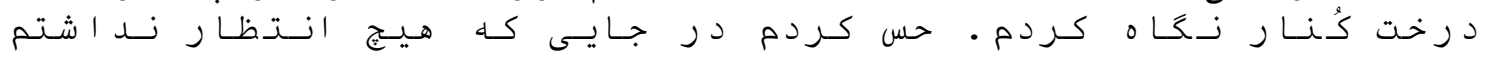

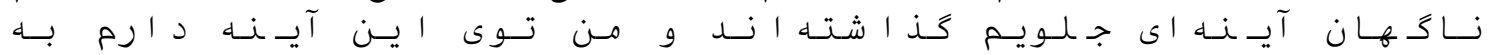

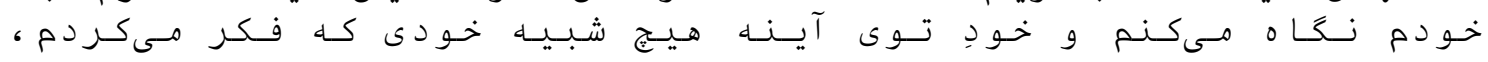

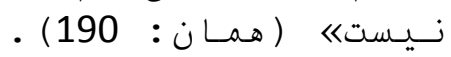

\section{3.}

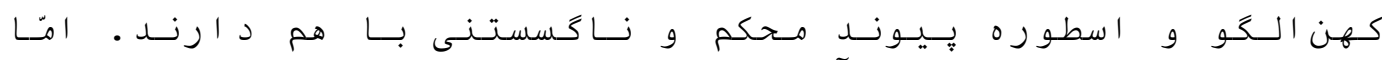

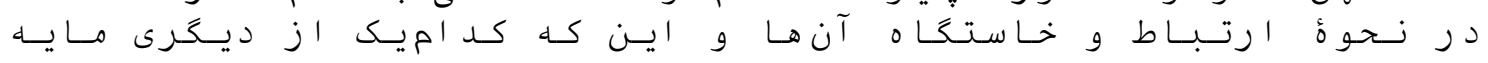

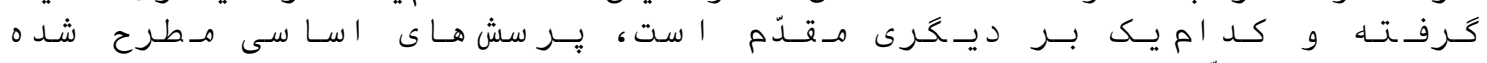

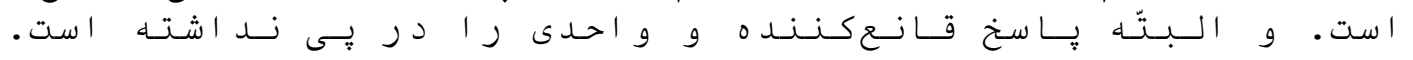

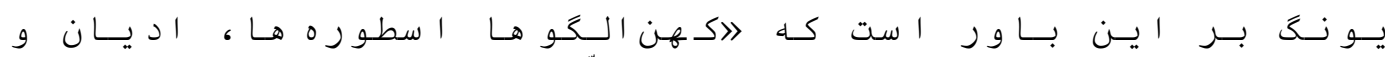

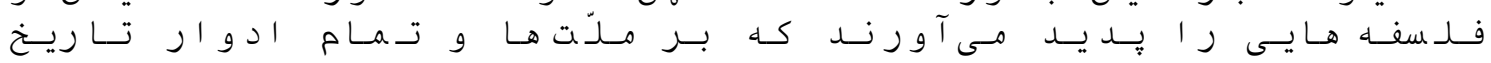

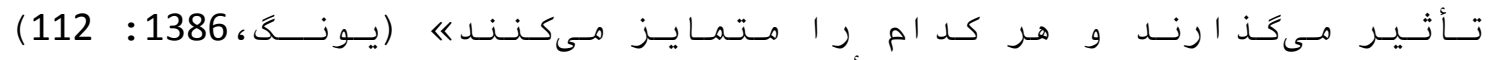

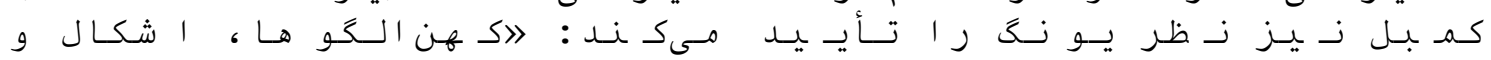

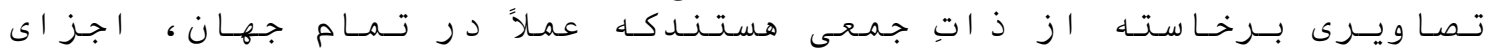

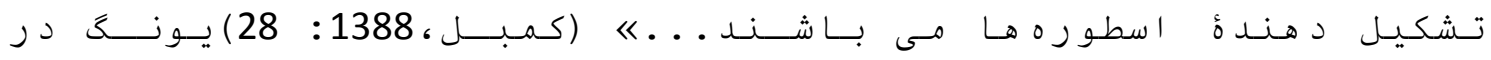

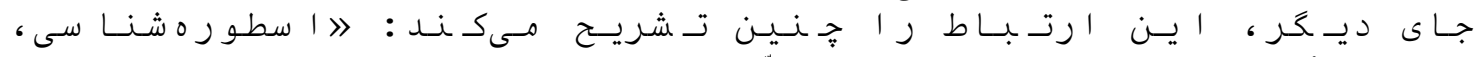

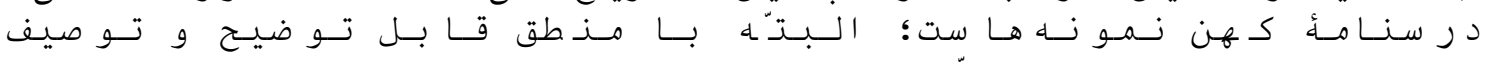

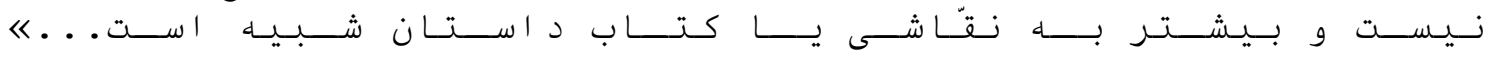

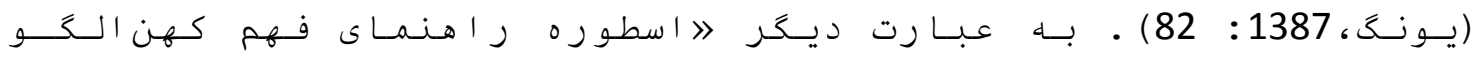

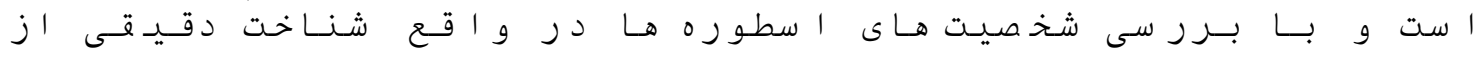

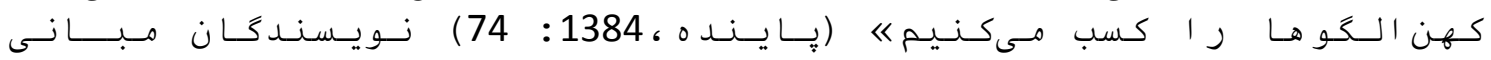

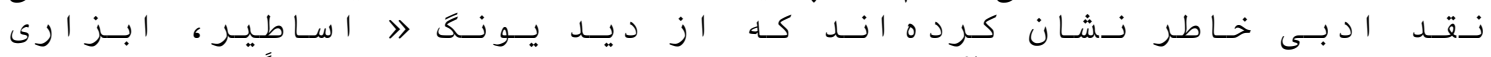

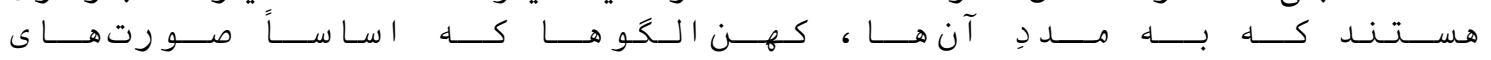




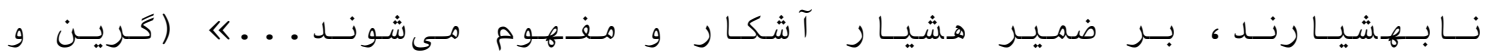

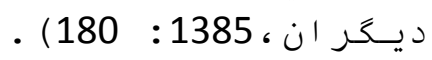

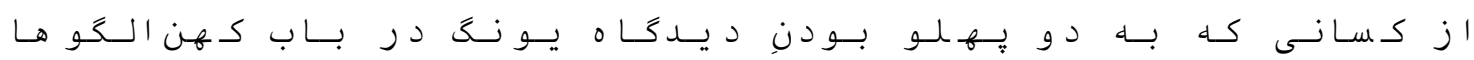

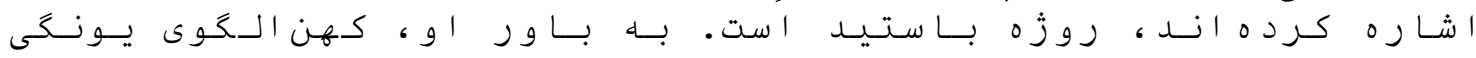

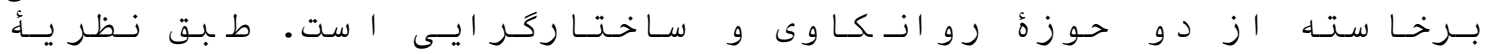

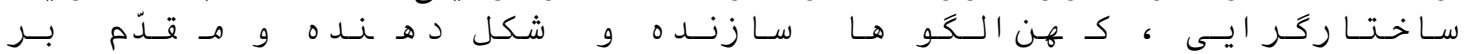

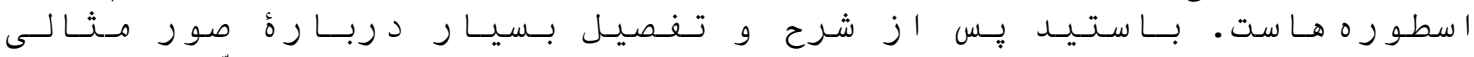

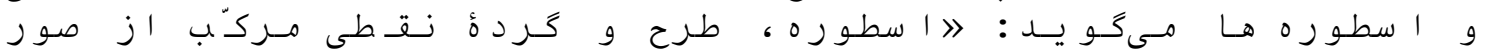

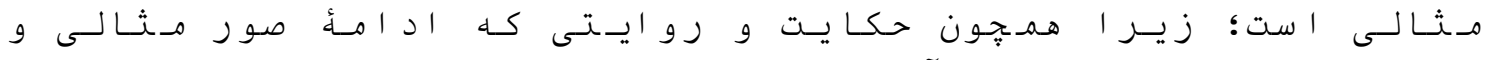

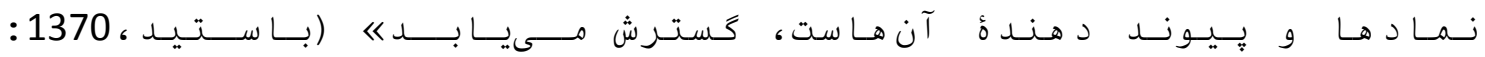

:1393)

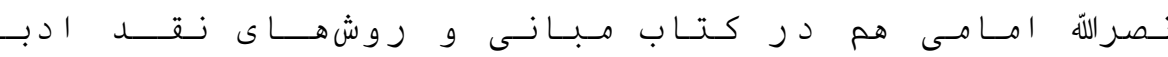

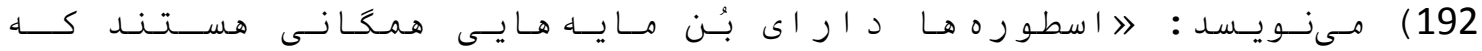

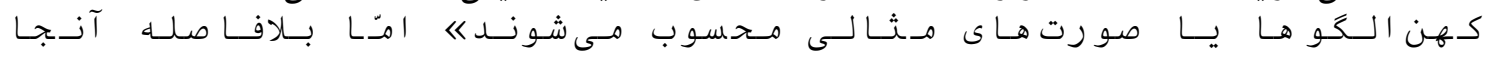

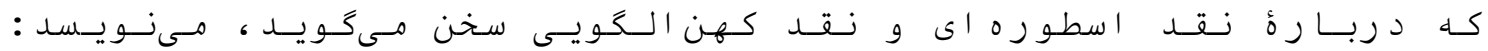

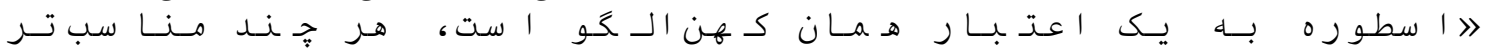

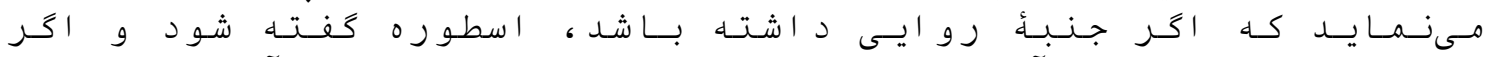

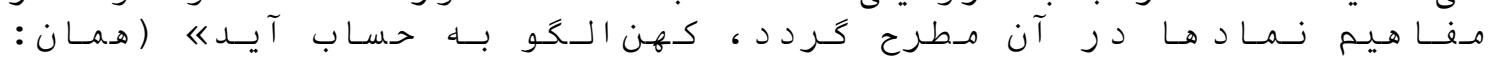

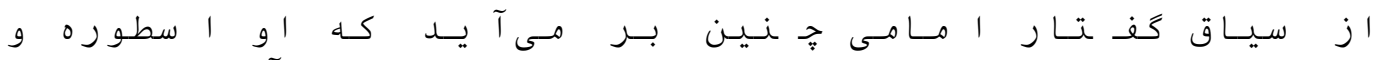

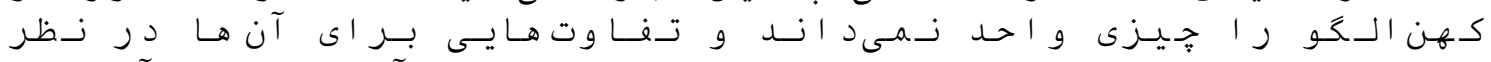

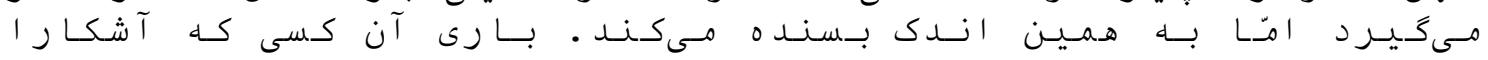

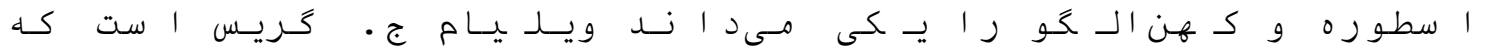

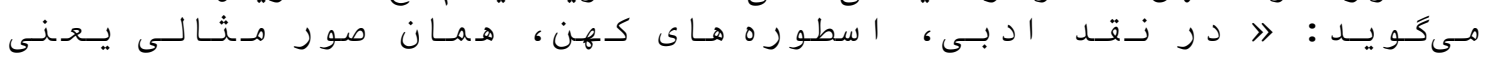

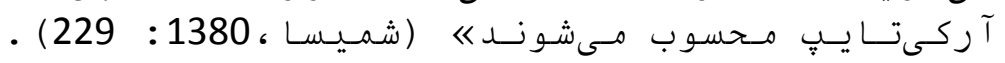

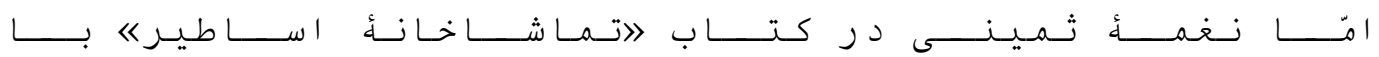

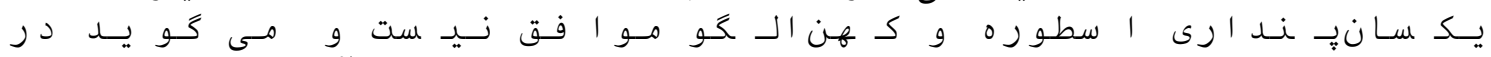

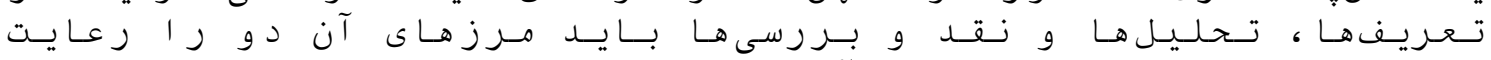

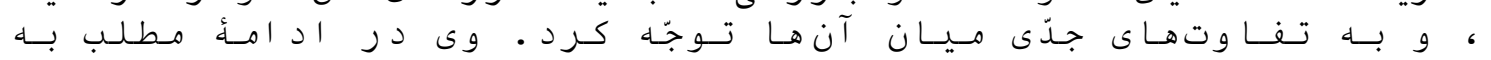

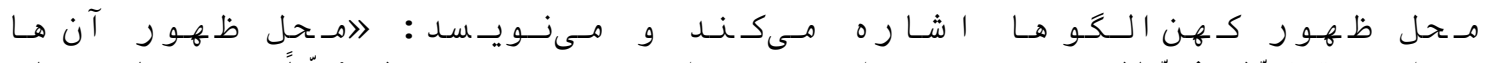

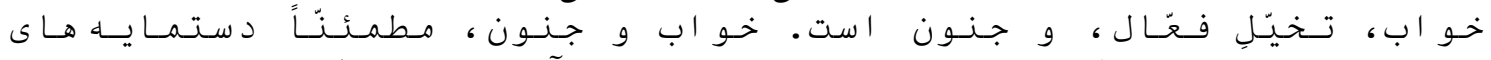

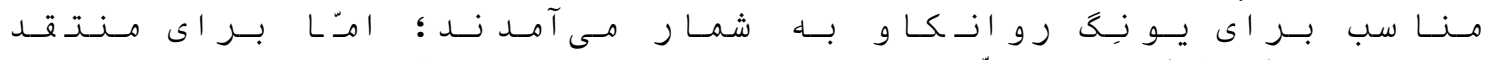

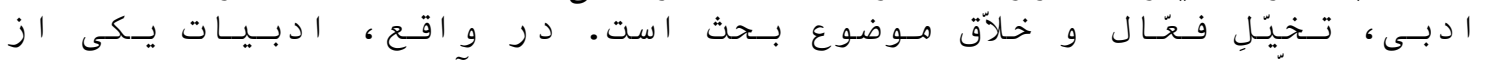

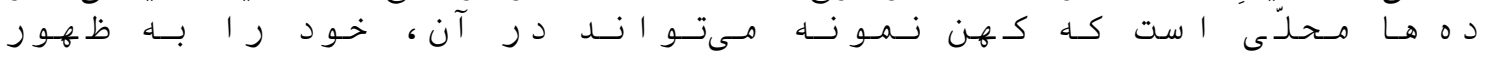

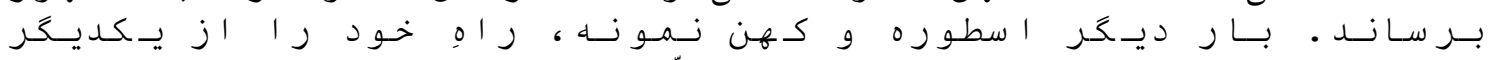

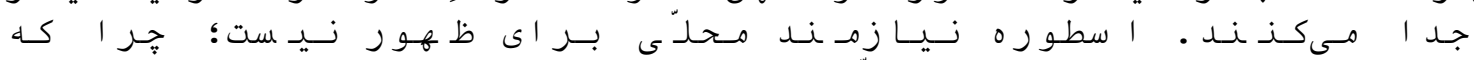

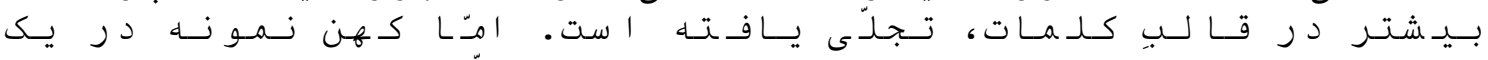

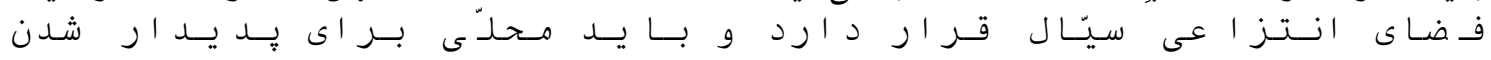

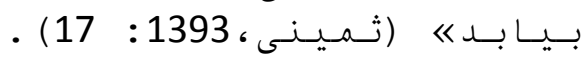

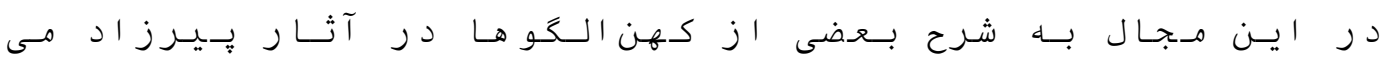
: يـرد إزيـم

\section{1}

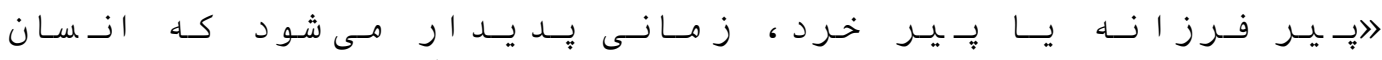

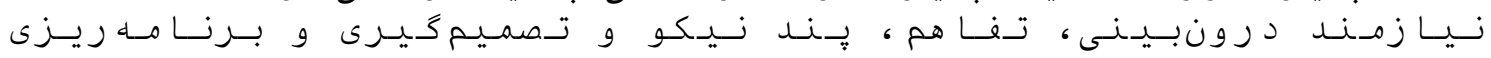




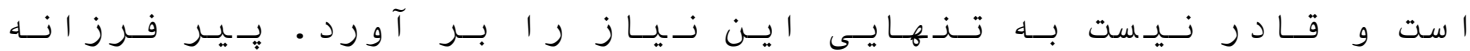

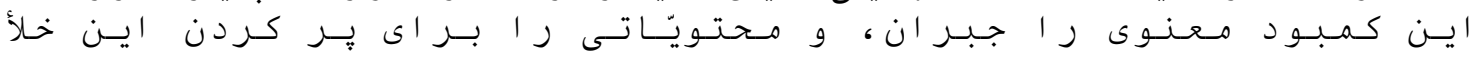

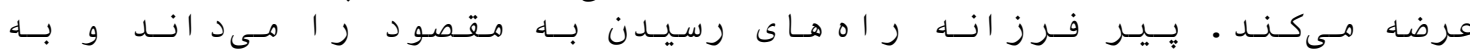

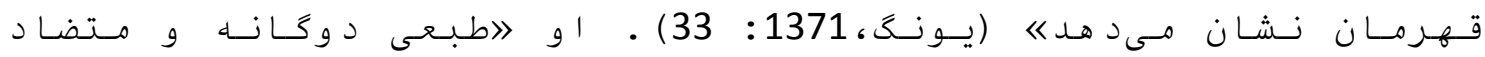

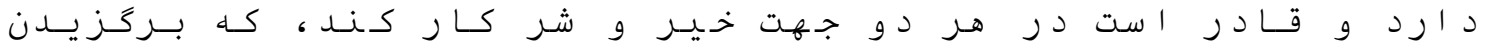

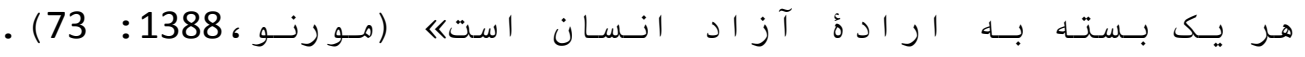

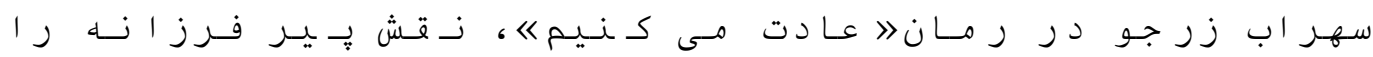

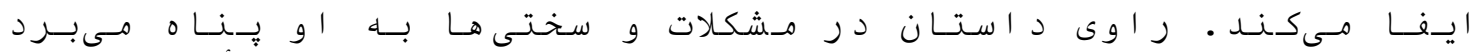

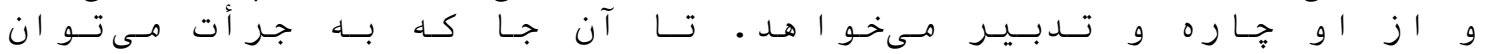

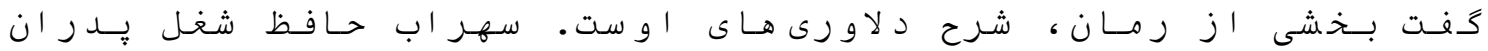

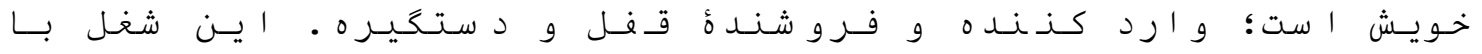

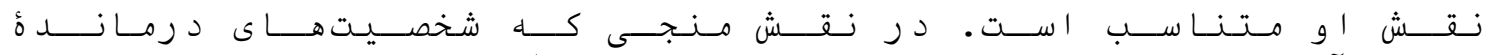

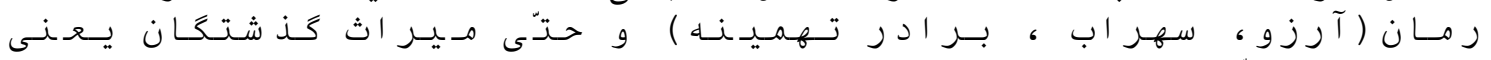

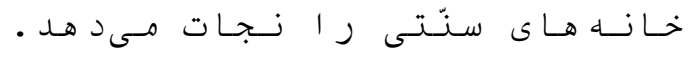

\section{( 2 . 3.}

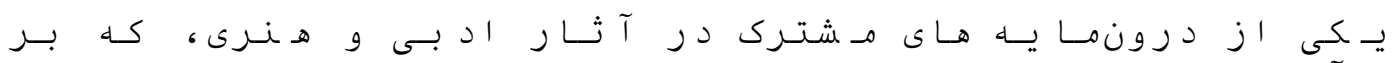

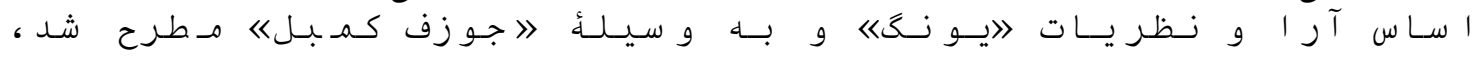

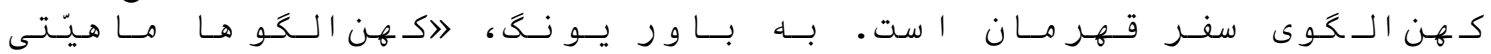

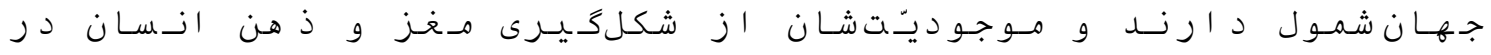

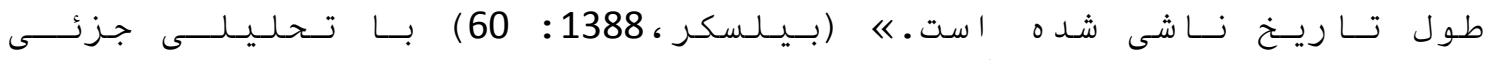

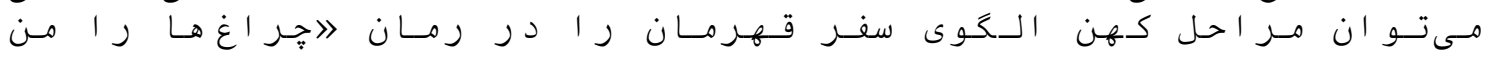

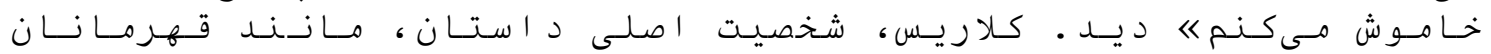

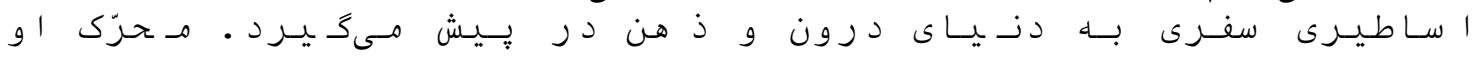

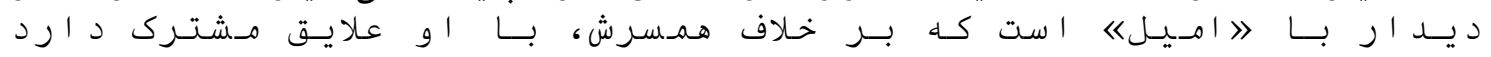

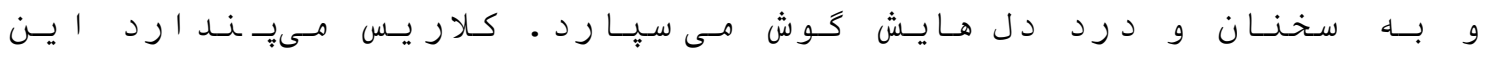

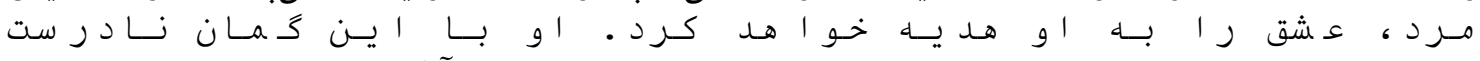

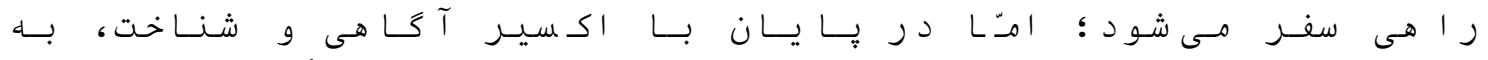

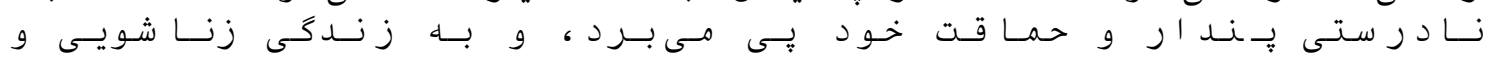

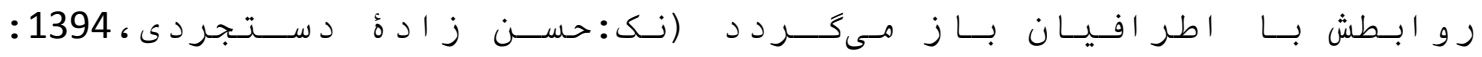

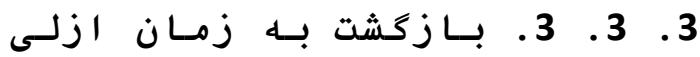

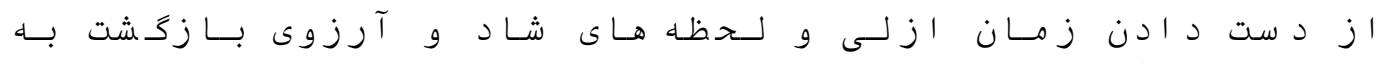

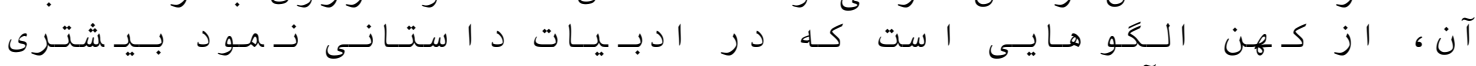

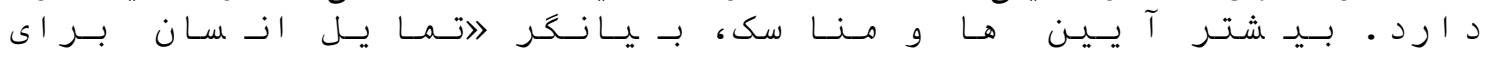

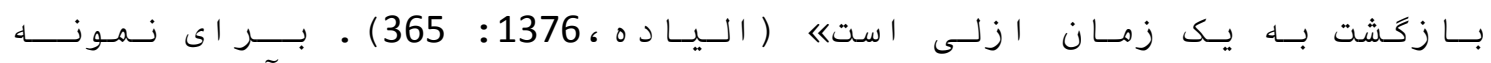

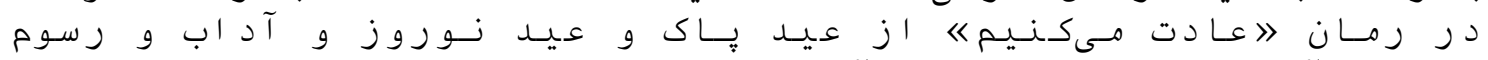

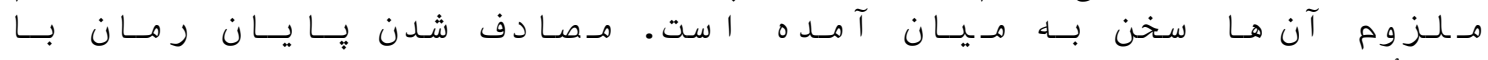

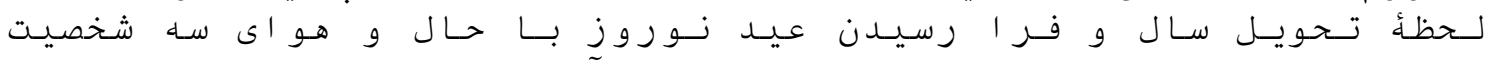

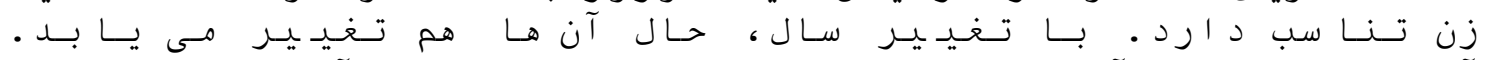

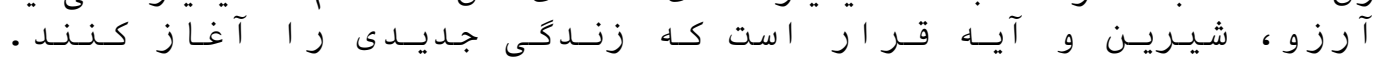

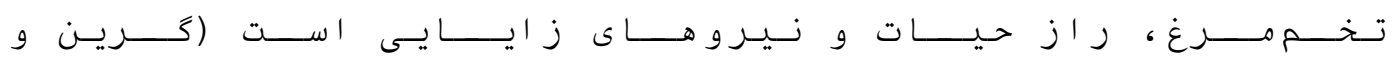

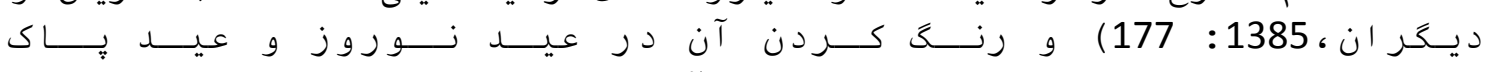

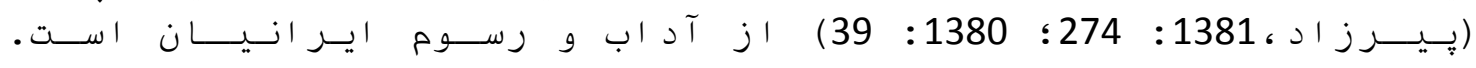




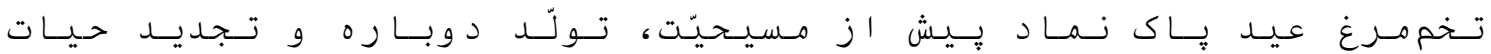

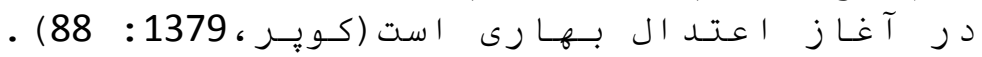

\section{4.}

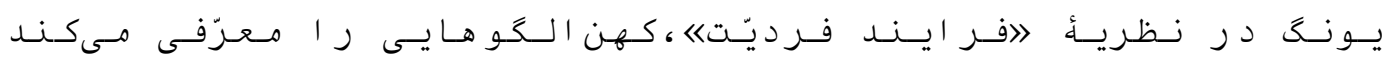

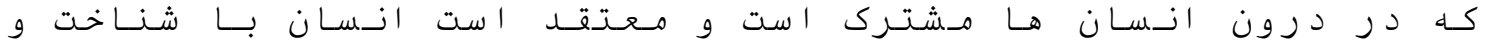

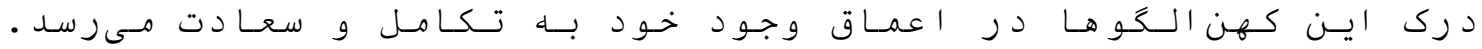

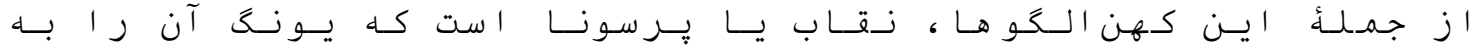

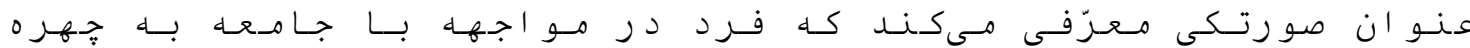

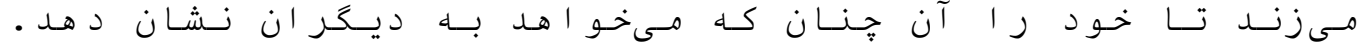

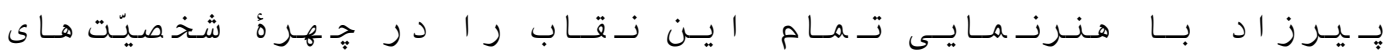

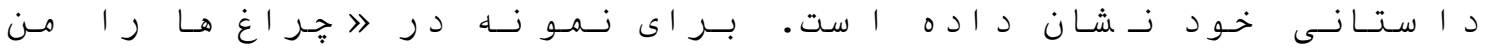

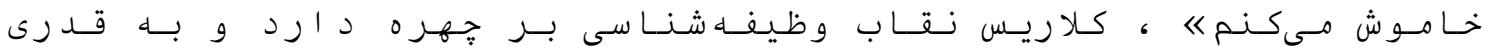

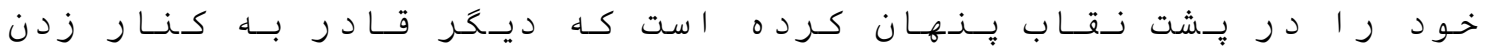

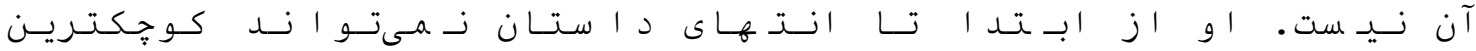

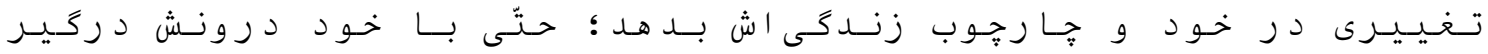

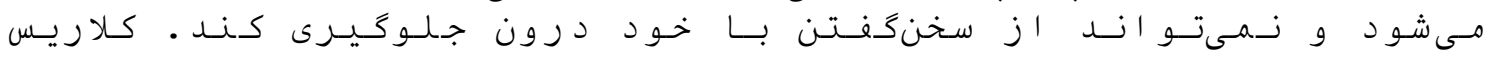

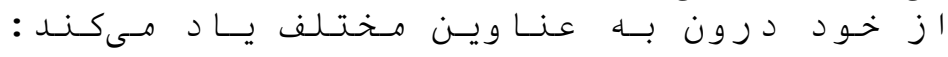

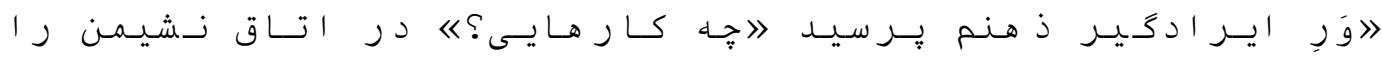

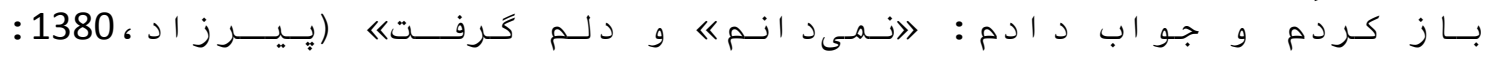

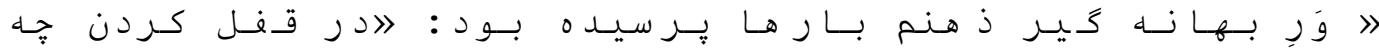

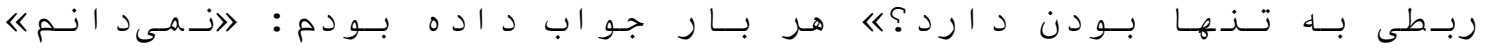

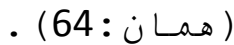

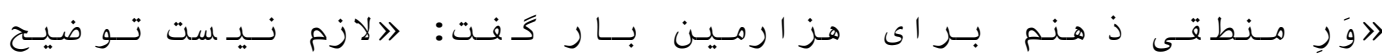

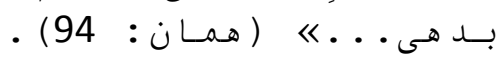

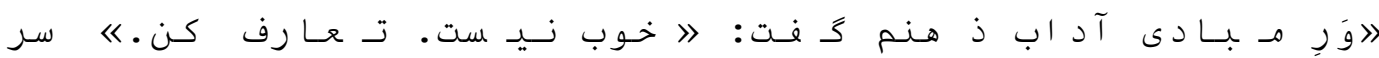

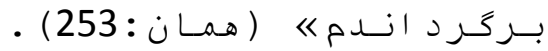

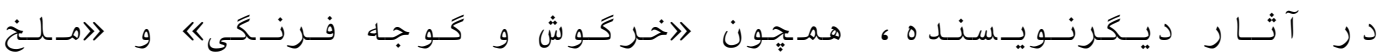

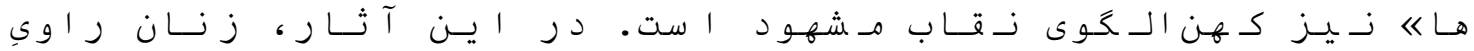

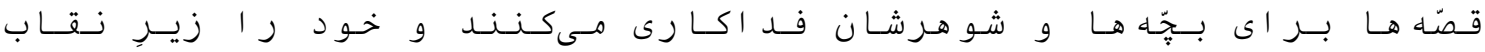

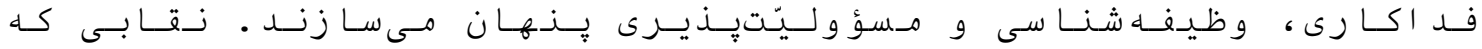

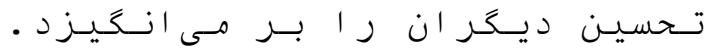

\section{$\begin{array}{llllll}\dot{\varepsilon} & \text { غ } 3 & \text {. } 3 & .5\end{array}$}

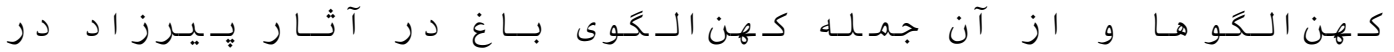

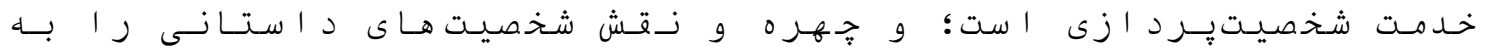

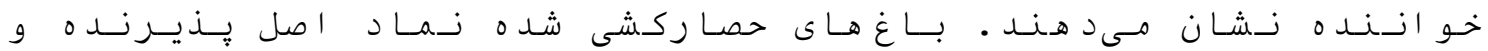

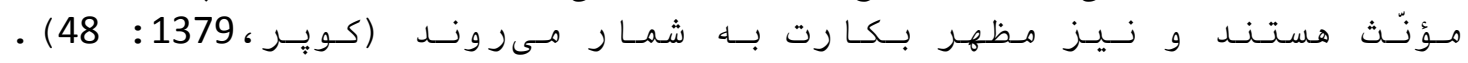

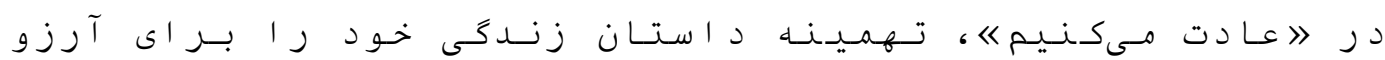

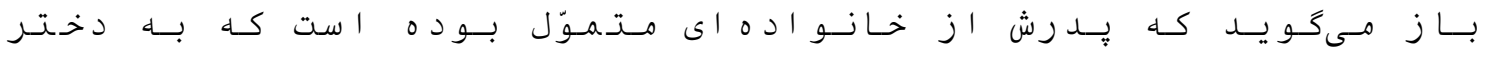

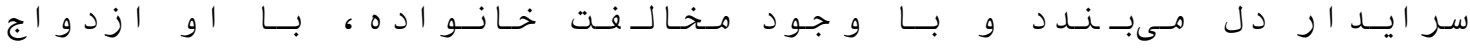

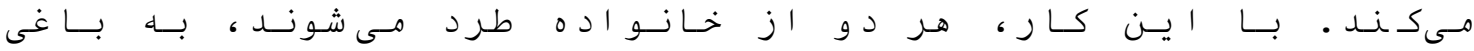




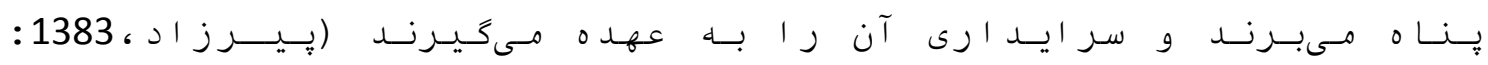
. $(258,204$

\section{(1)}

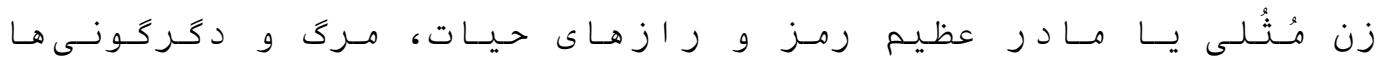

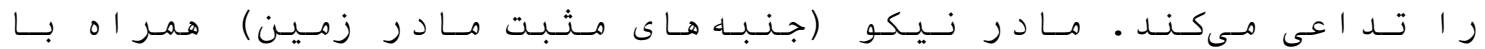

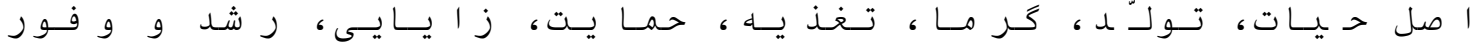

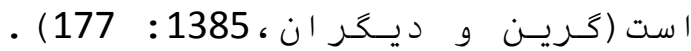

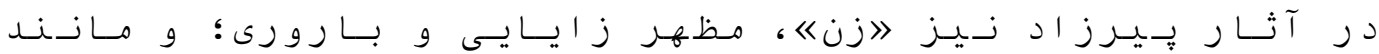

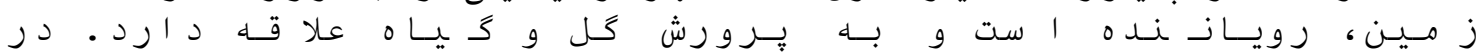

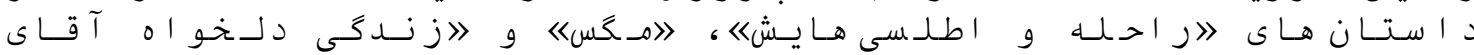

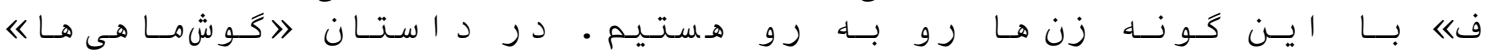

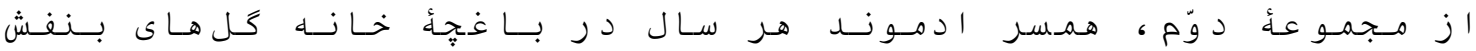

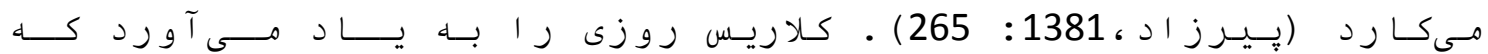

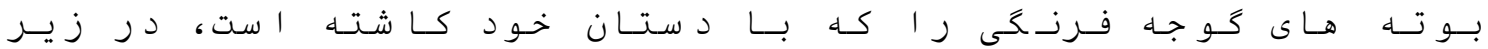

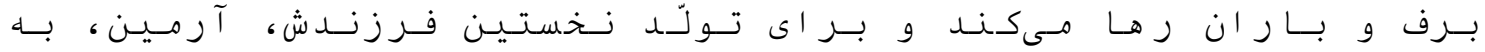

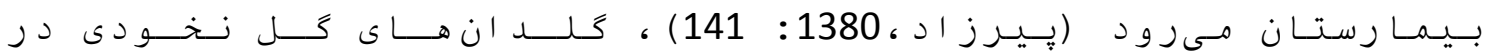

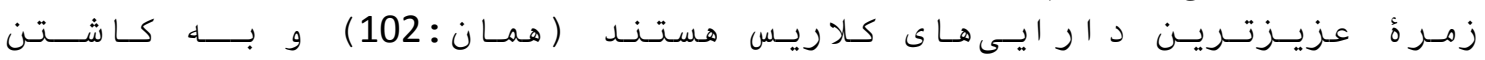

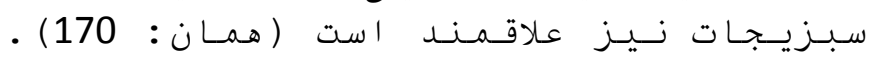

\section{3.}

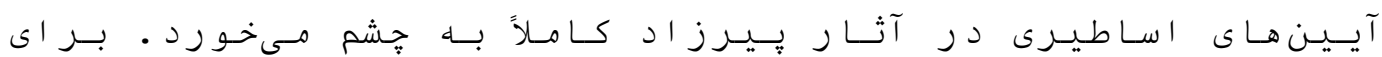

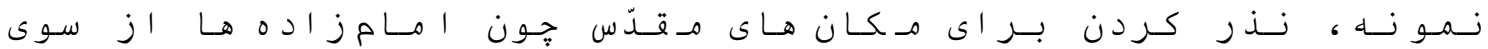

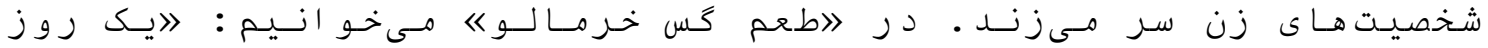

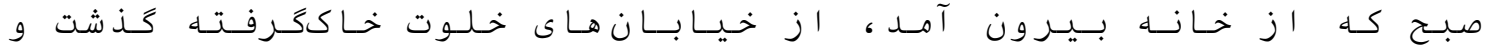

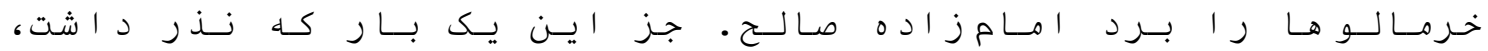

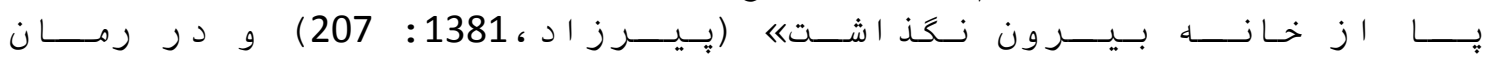

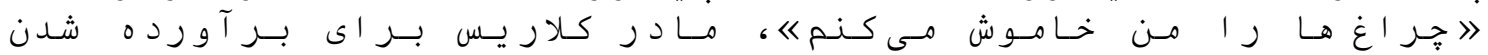

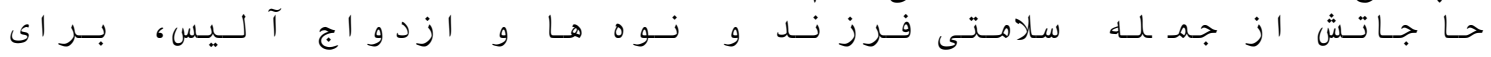

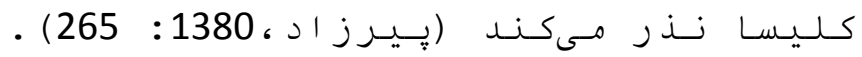

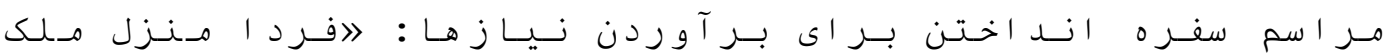

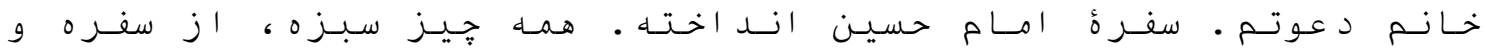

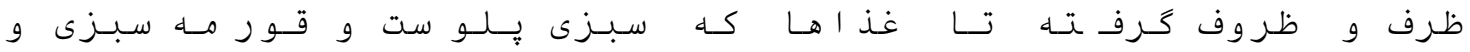

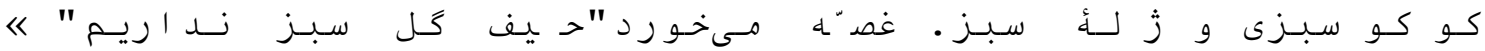

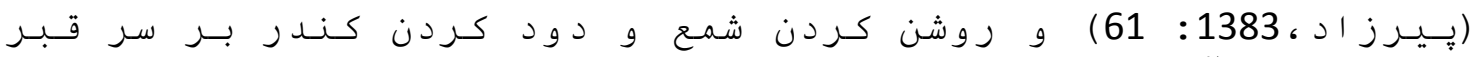

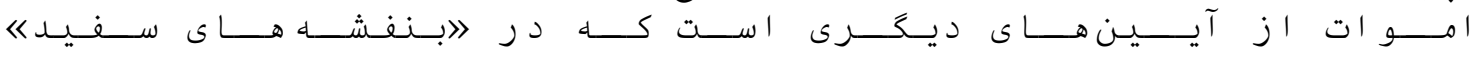

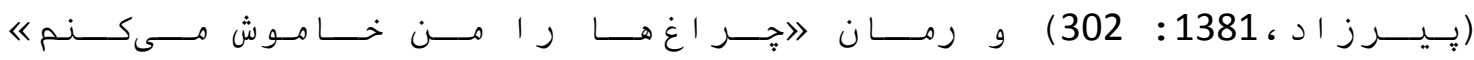

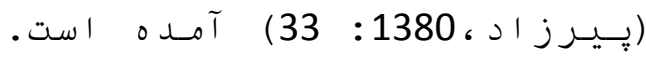

5. 3.

(Totem) 1.

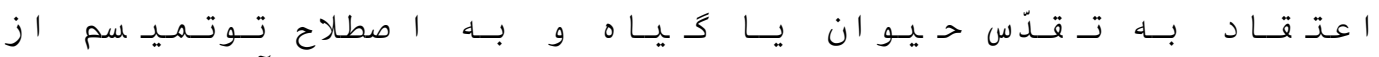

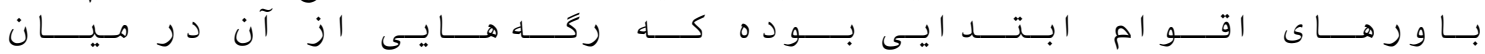




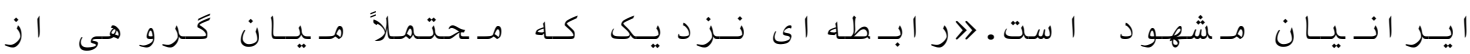

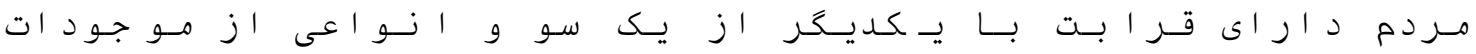

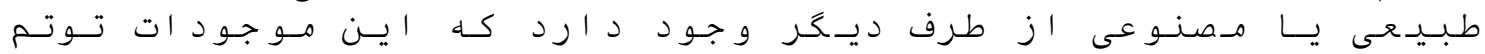

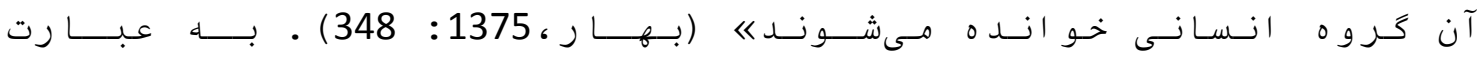

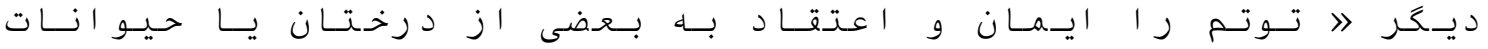

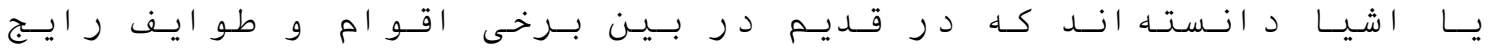

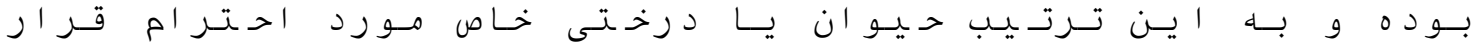

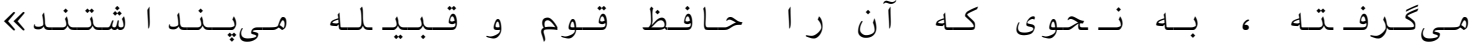

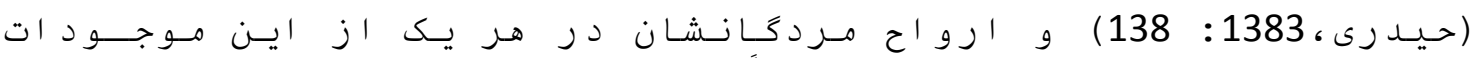

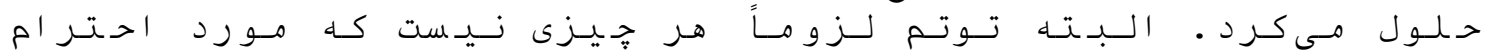

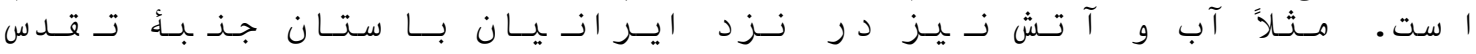

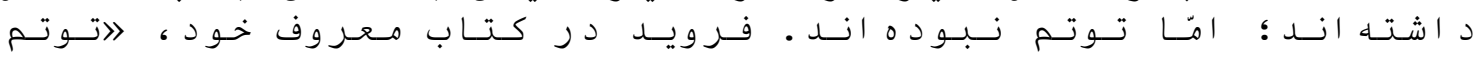

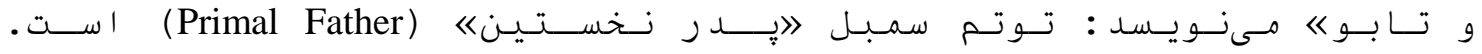

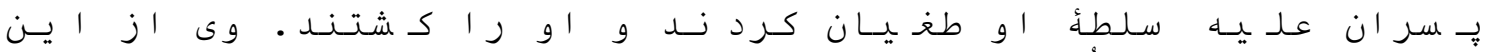

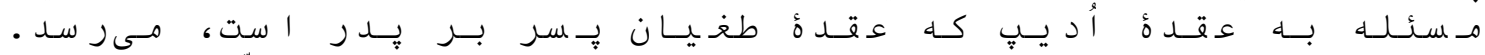

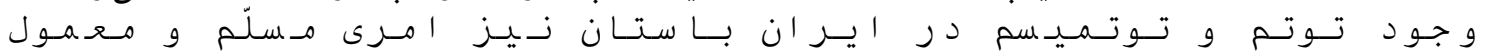

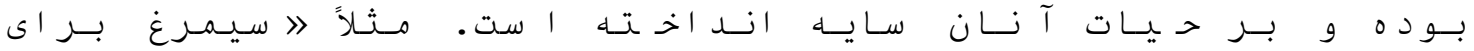

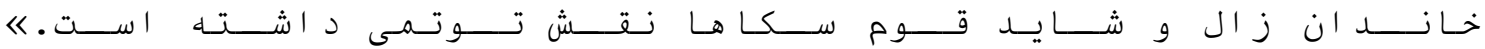

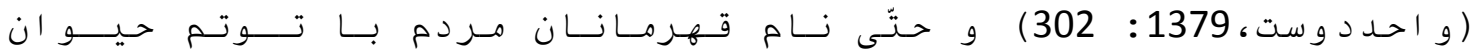

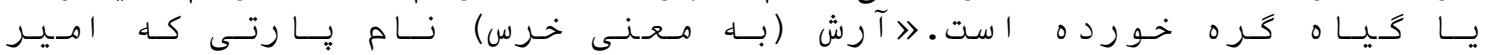

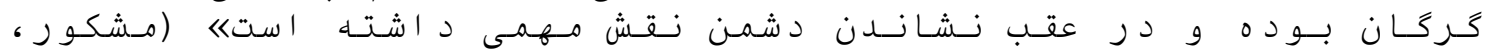

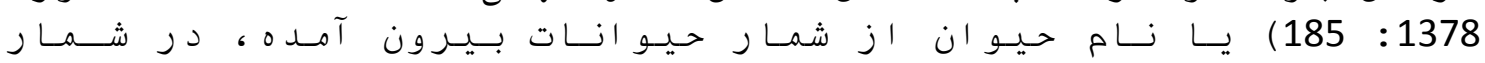

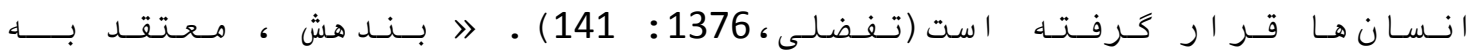

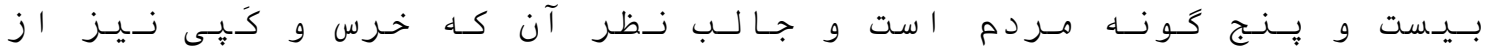

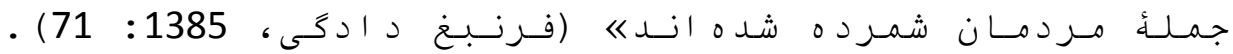

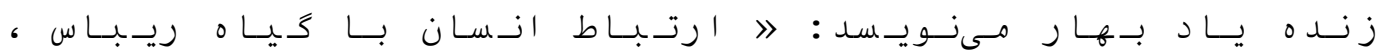

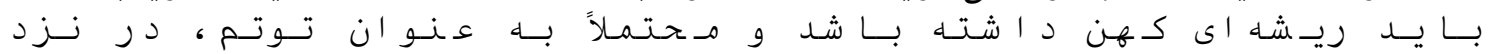

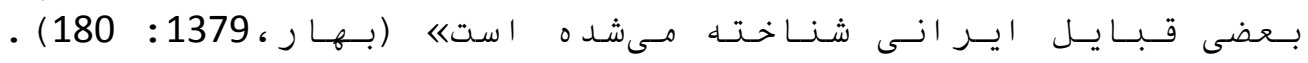

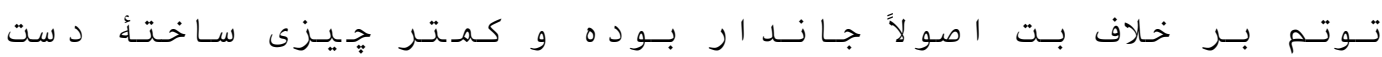

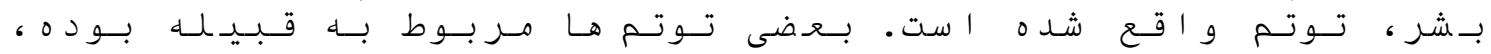

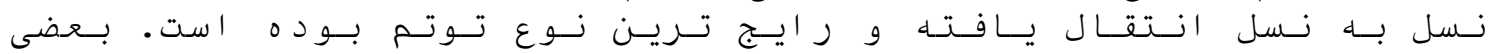

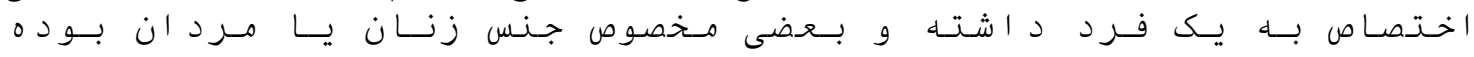
|

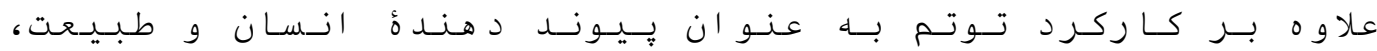

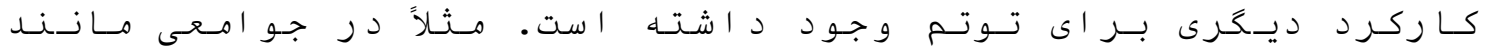

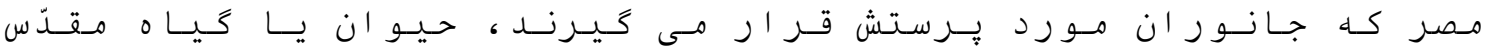

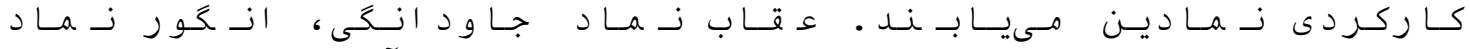

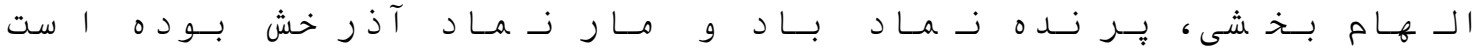

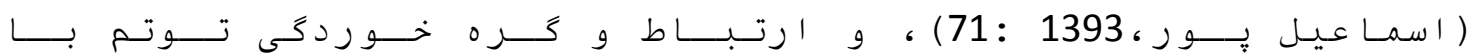

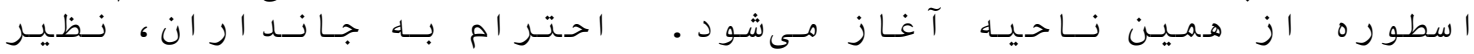

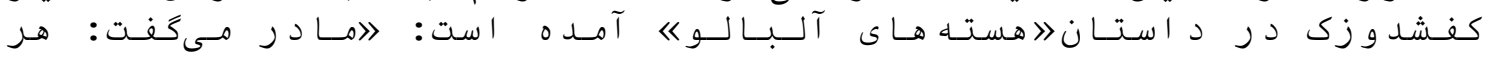

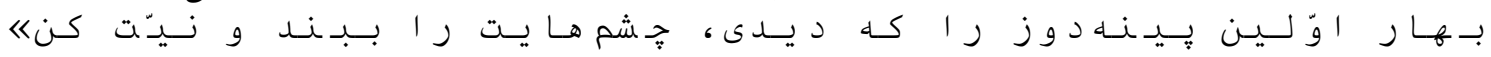

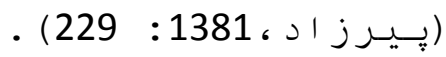

\section{2.}




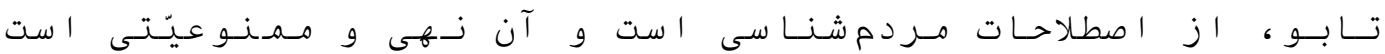

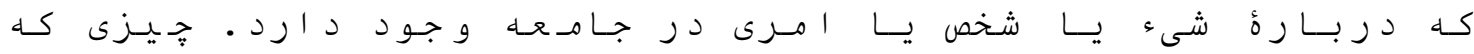

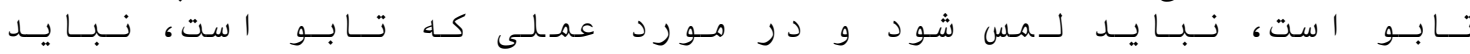

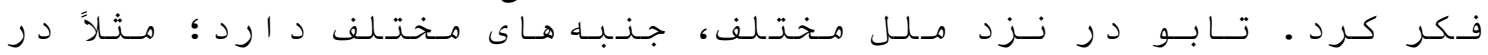

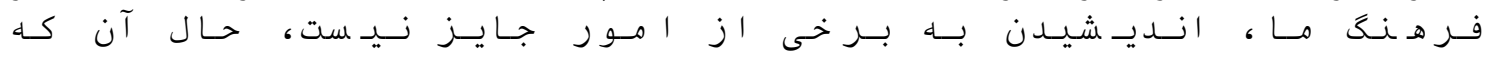

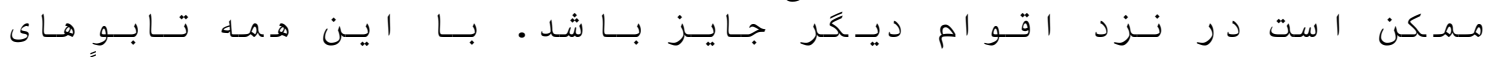

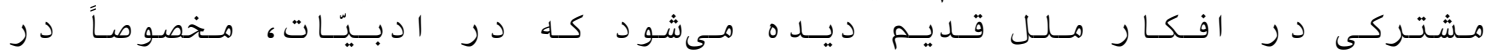

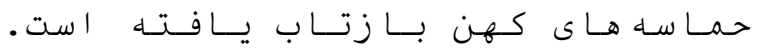

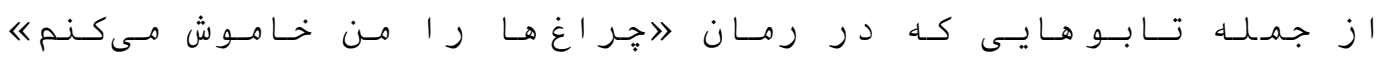

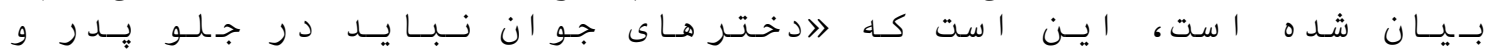

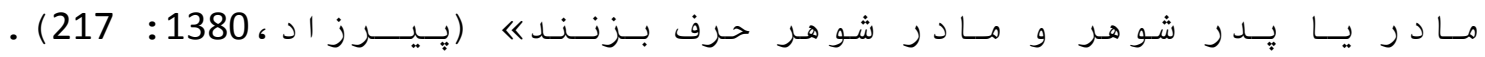

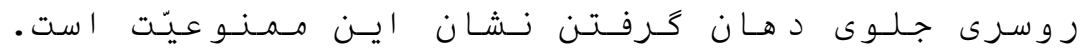

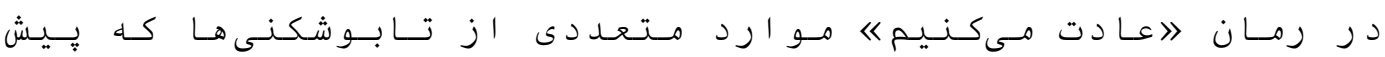

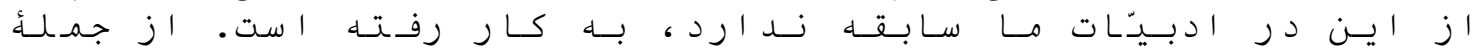

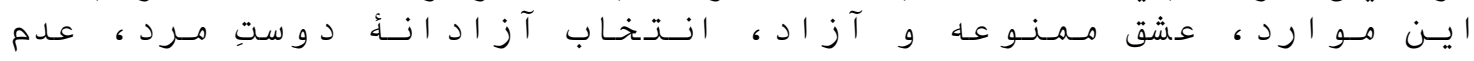

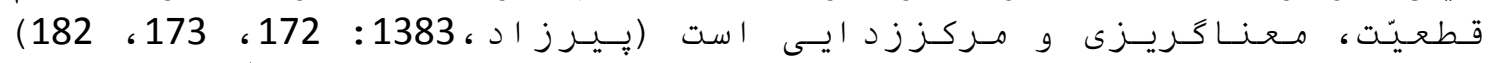

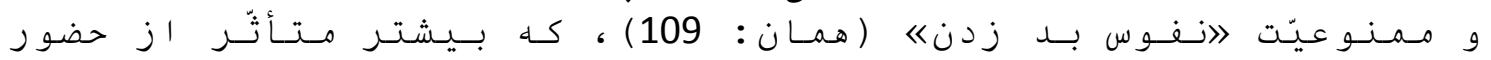

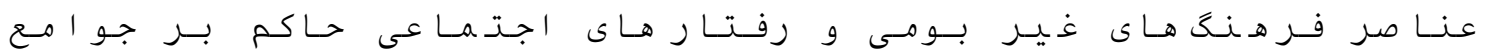

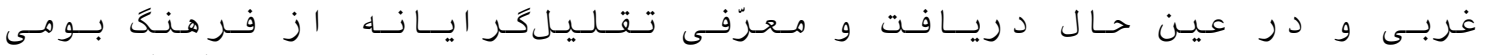

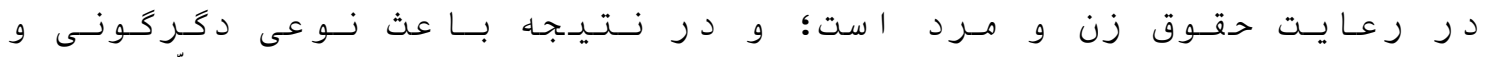

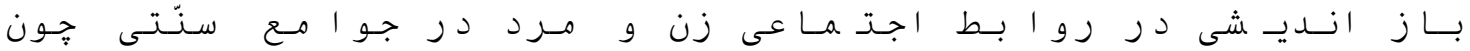

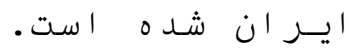

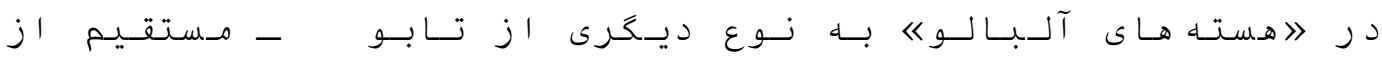

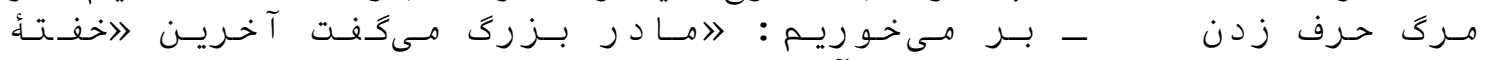

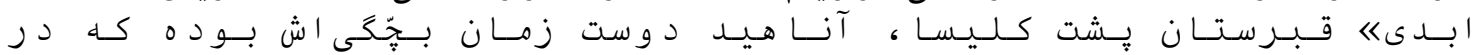

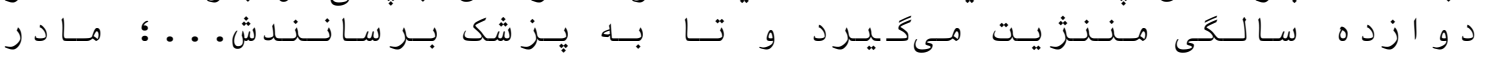

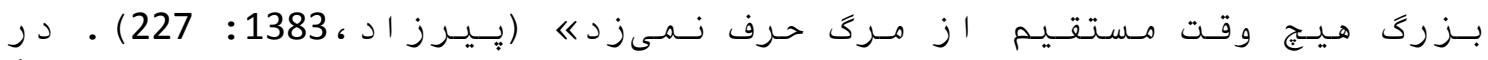

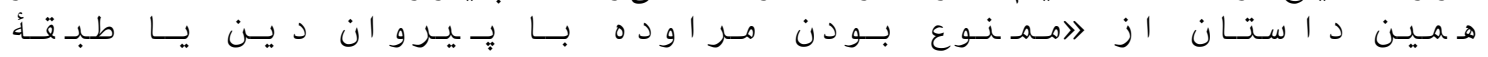

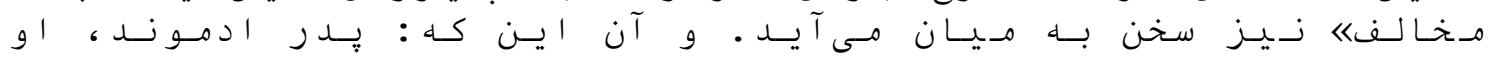

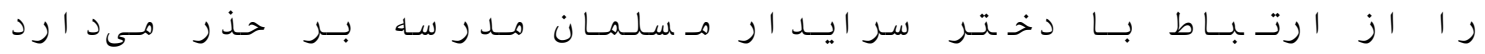
. (همان :

\section{3.}

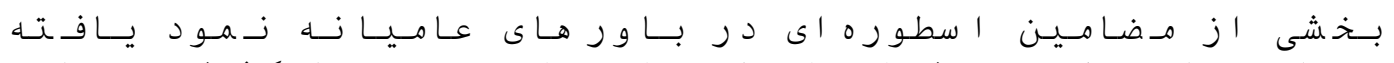

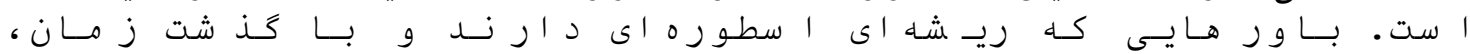

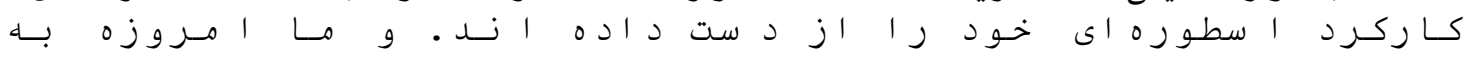

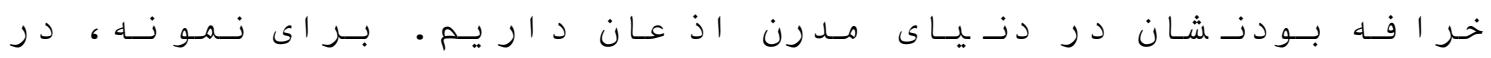

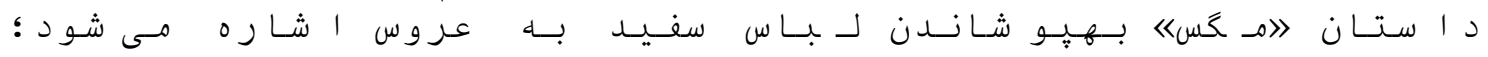

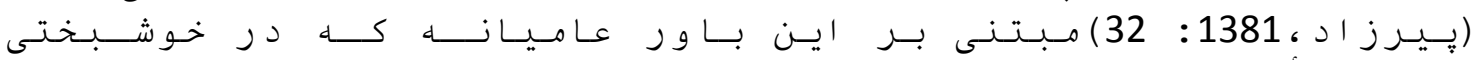

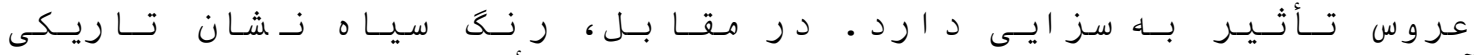

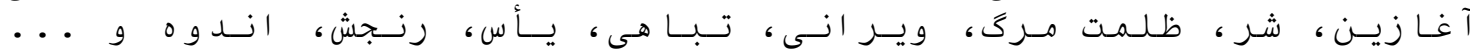

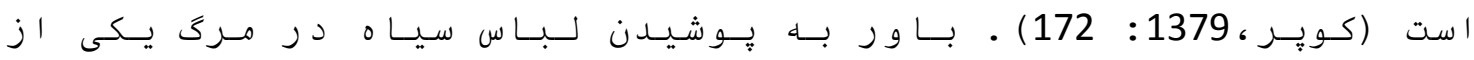

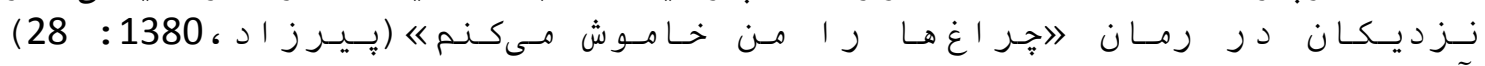

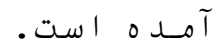

\section{نـتـيـجـا}




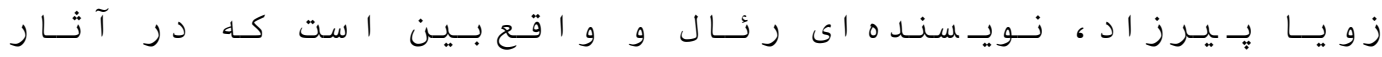

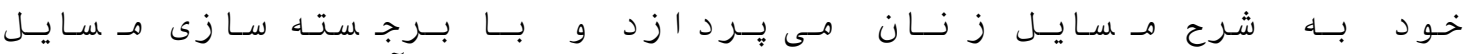

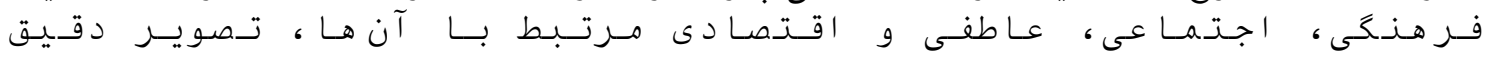

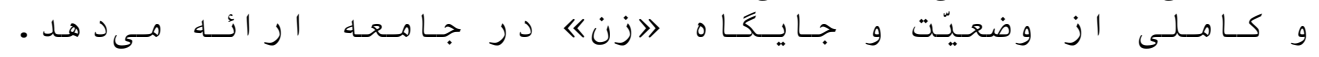

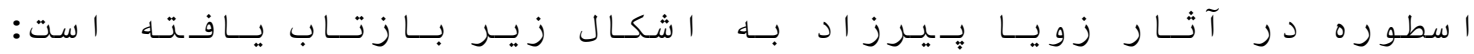

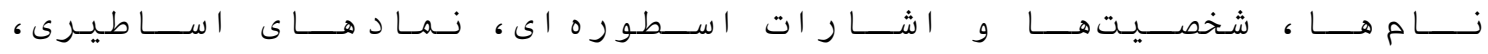

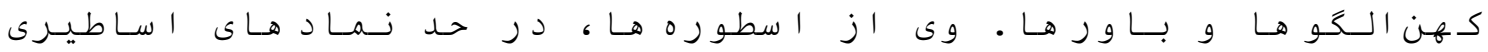

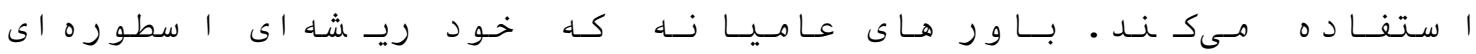

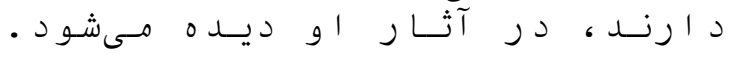

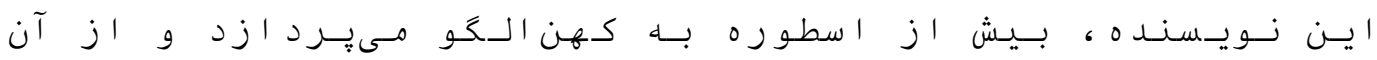

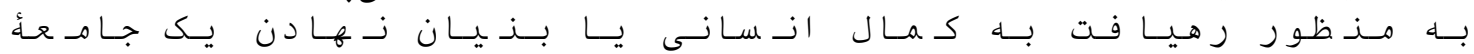

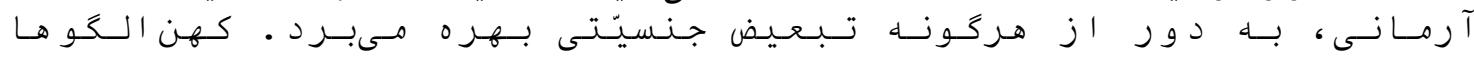

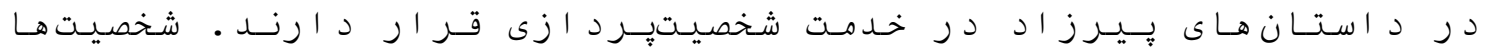

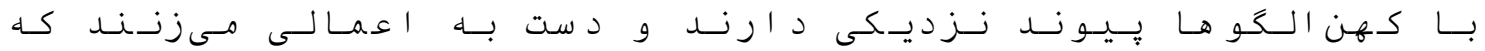

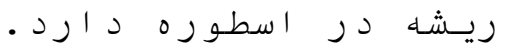

\section{مـنـا بـع}

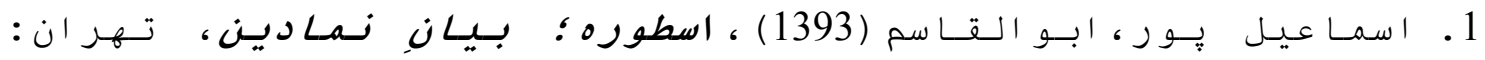

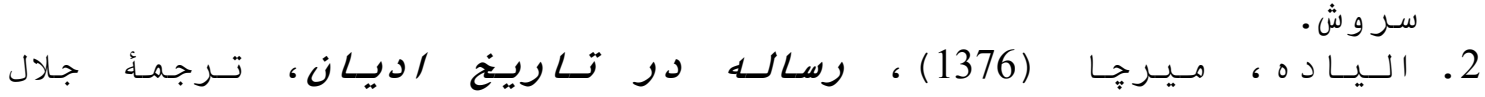

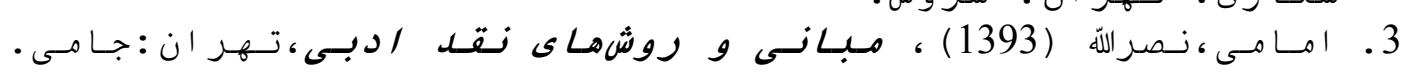

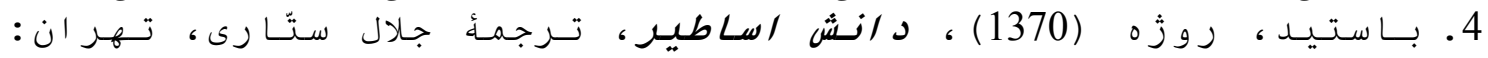

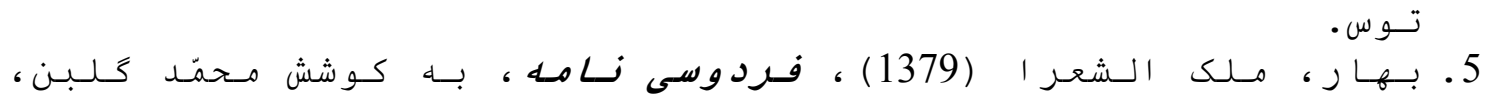

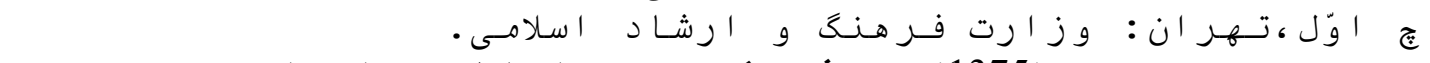

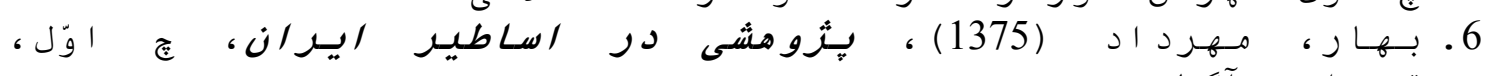

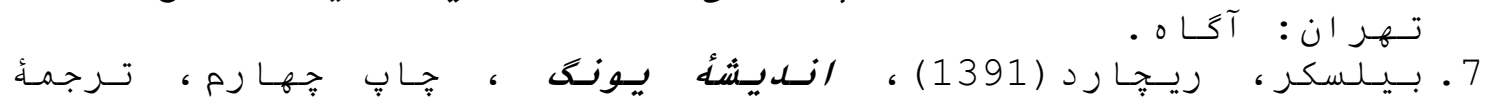

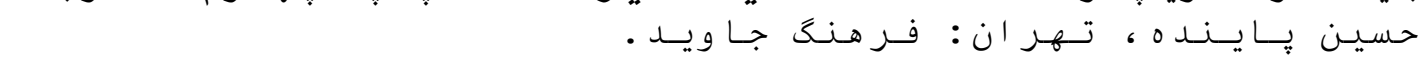

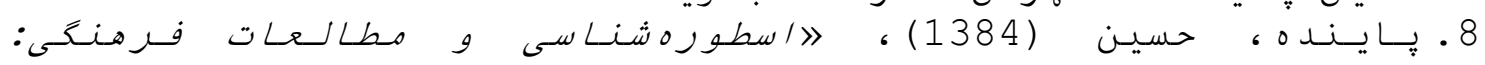

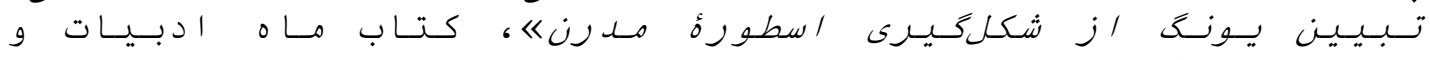

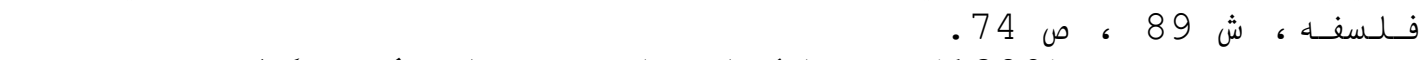

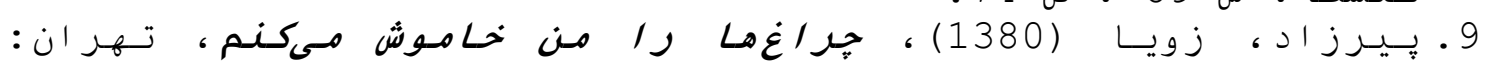

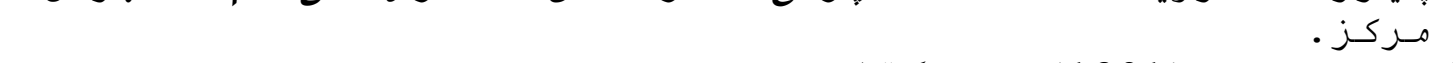

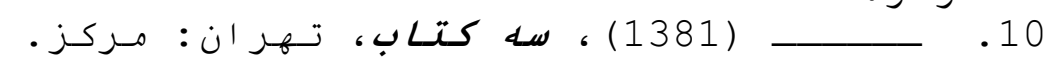

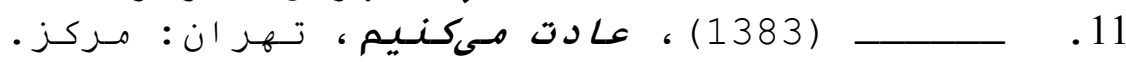

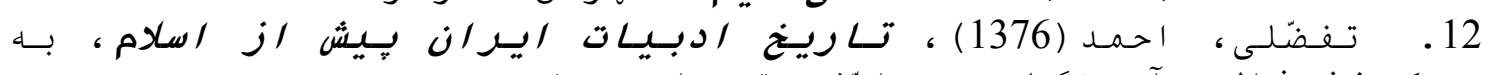

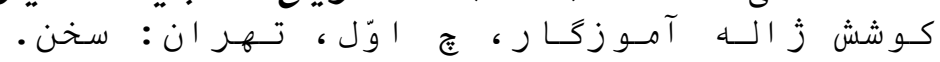

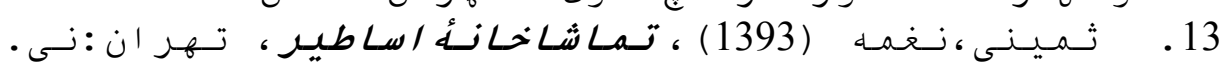

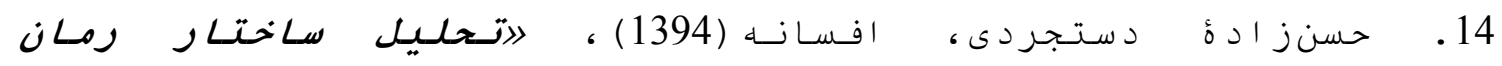

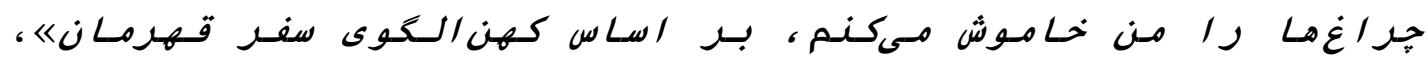

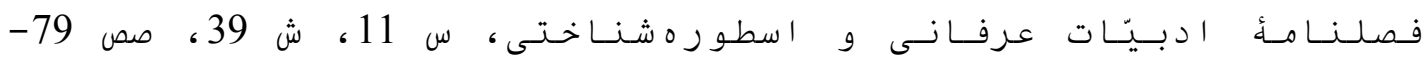




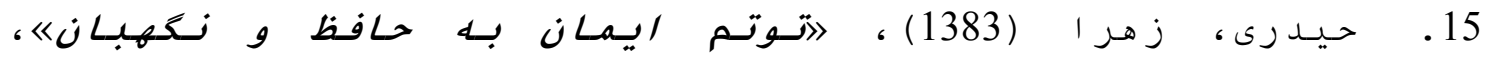

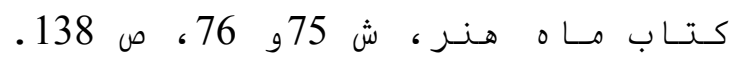

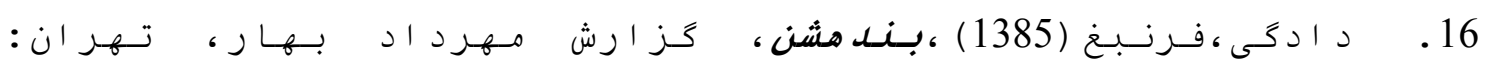

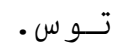

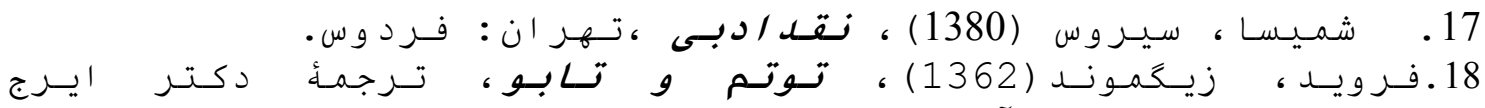

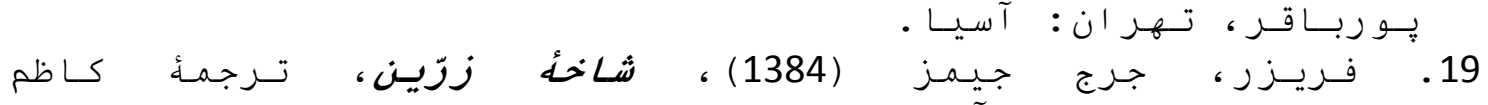

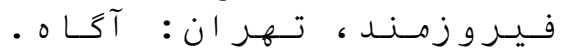

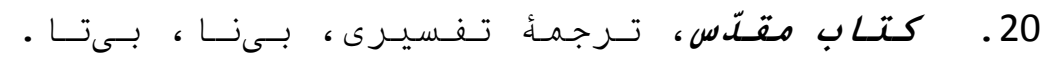

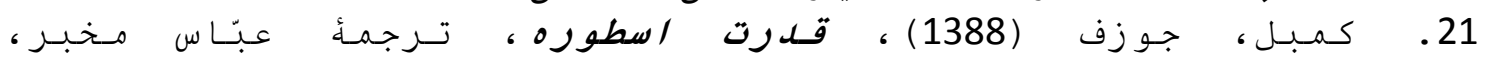

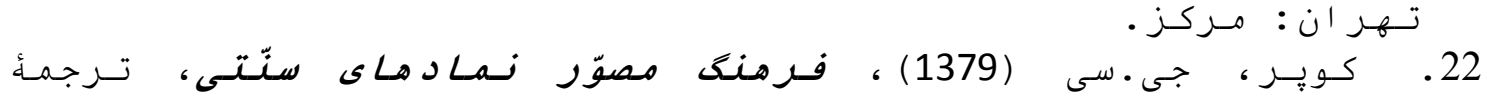

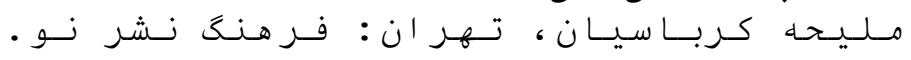

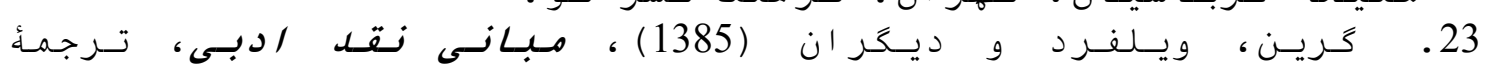

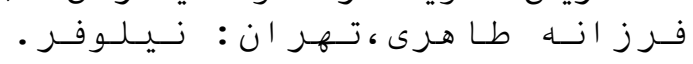

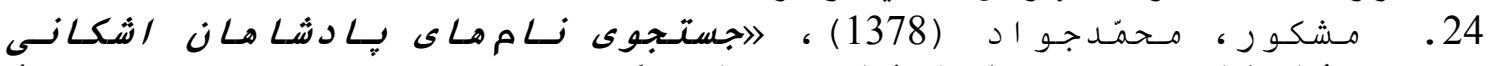

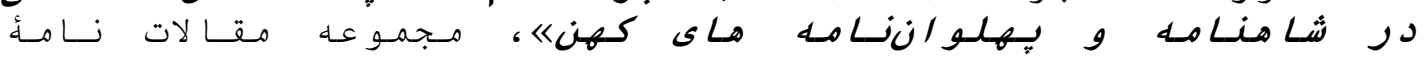

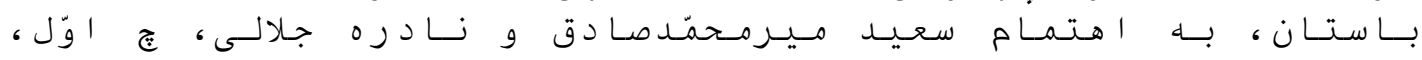

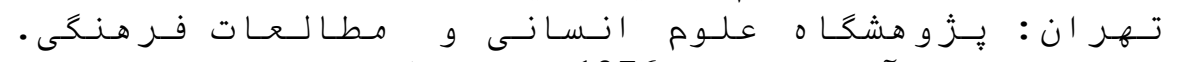

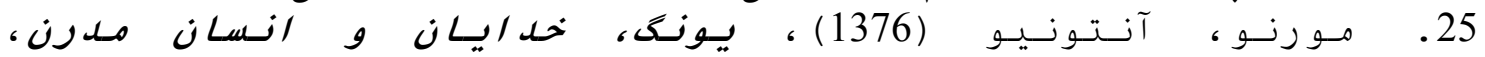

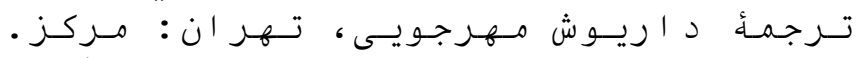

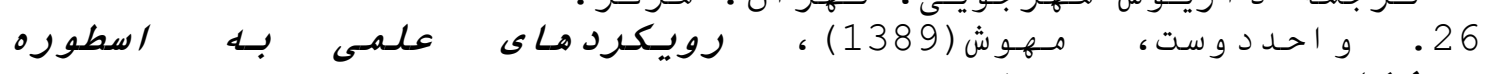

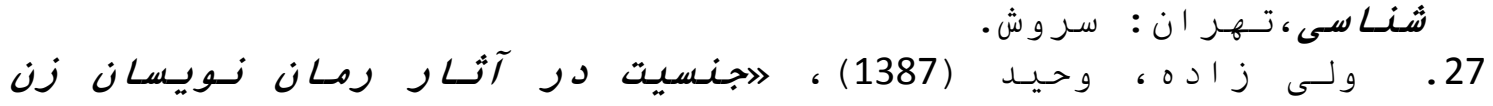

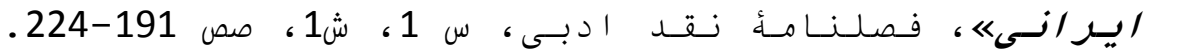

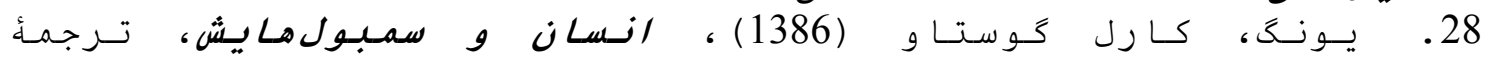

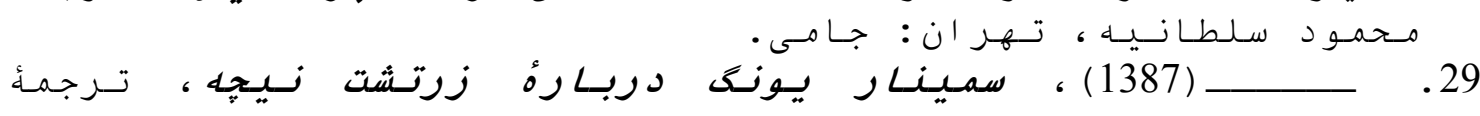

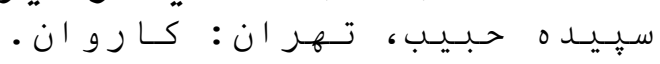

